\title{
Seamen on Land? A Preliminary Analysis of Medieval Ship Graffiti on Cyprus
}

\author{
Stella Demesticha \\ Department of History and Archaeology, University of Cyprus, Nicosia, Cyprus
}

\author{
Katerina Delouca \\ Independent Researcher
}

Mia Gaia Trentin

STARC, The Cyprus Institute; NCSA, University of Illinois at Urbana-Champaign

\author{
Nikolas Bakirtzis \\ STARC, The Cyprus Institute, Nicosia, Cyprus
}

\author{
Andonis Neophytou \\ Department of History and Archaeology, University of Cyprus, Nicosia, Cyprus
}

This article reports on the results of a research project entitled 'KARAVOI. The Ship Graffiti on the Medieval Monuments of Cyprus: Mapping, Documentation and Digitisation', during which 233 ship graffiti were recorded in 44 different monuments on the island, dating from the 15 th to the 20 th centuries. Innovative recording techniques have been used to mitigate the effects of the subjective or partial recording of graffiti lines on tracing paper. Apart from the study of ship graffiti as iconographic sources, particular emphasis has been given to their geographical and social context through a comprehensive analysis of the graffiti types and their spatial distribution in the monuments as well as the monuments location on the island.

(C) 2017 The Authors

Key words: ship iconography, ship graffiti, Cyprus, churches, graffiti documentation.

$\mathrm{P}$ ictorial graffiti in archaeological and architectural contexts are drawings of unsophisticated character, often carved with a sharp tool on various surfaces - plaster, stone, ceramic, or wood-by people that frequented public spaces, sacred places, workspaces or prisons (Bucherie, 1992: 47; Le Bon, 1995: 172; Baird and Taylor, 2011: 1-3). These informal and rapidly executed iconographic representations of diverse aspects of daily life represent unique testimonies of thoughts or messages expressed directly by their carvers; as such, they represent a valuable source for the study of past societies (Keegan, 2014: 4-15).

Nautical, maritime, or simply ship graffiti (SG) have a particular place in the scholarship of maritime archaeologists, having been extensively used as an iconographic source (see for example Basch,
1987). Bucherie (1992) has classified ships-together with humans, animals, vegetables, structures and architecture, clothes, utensils or tools, and vehicles - as designs related to the life experiences of their author. Artzy (1999: 21-22) considered graffiti found in churches or temples as ex votos, tokens of thanks, prayer, protection, or vows to some divinity. She also suggested that ships engraved in baths, streets, or working places may just be drawings scratched to pass the time. Similarly, Christensen (1995: 184) saw such contexts studied in Scandinavian sites as the work of men who lived in maritime societies and thus had a strong interest in ships, whereas Le Bon (1995) noticed some repetitive motifs, such as the ship's bow, and argued that they were used to communicate concepts, not to depict real ships. Westerdahl (2013: 337) suggested the term 'carvings' 
was more appropriate, especially for representations of ships found on religious monuments, because the word graffito, having an 'illicit, casual and nonconformist aspect', expresses an a priori interpretation. As we demonstrate below, however, not all ships carved on the walls of churches should be classified as votive; thus we maintain the term graffito in this paper.

A significant number of SG has been recorded in many western Mediterranean countries (see also Bucherie and González, 2000): Spain (González and Pastor, 1993; González Gozalo, 2006, 2017; Hermanns, 2010; Barrera Maturana, 2011), France (David, 1965; Auger-Sergent, 1996), Malta (Cassar, 1966; Muscat, 1997), and Italy (Bonino, 1975; Helms, 1975; Arduini and Grassi, 2002). They have been found in monuments of different character, such as caves, temples, public buildings, fortifications, churches, prisons, and private houses, dating to various periods, from the $3 \mathrm{rd}$ millennium BC onwards (Basch, 1987). In the eastern Mediterranean, ancient SG have attracted the attention of several scholars (for example Doumas, 1965; Basch, 1987; Basch and Artzy, 1985; Artzy, 1999; Langdon and Van de Moortel, 1997; Pomey, 2006; Van de Moortel and Langdon, 2017) but those from medieval and later contexts have been recorded only sporadically, as for example those from the Black Sea (Emetz, 1995; Ocharov, 1995), Cyprus, Israel (Kahanov et al., 2008; Kahanov, 2011) and various areas in Greece: Attiki (Getakos, 1956; Meinardus, 1970-1972; Basch, 1978; Delouca, 2000; Damianidis, 2011); Aegina (Basch, 1986; Delouca, 1990, 1996); Mystras (Orlandos, 2000: 72-73, fig. 44) and Thessaloniki (Koniordos and Pelekanidou, 2001; Babuin and Nakas, 2011; Krapf and Nakas, 2017). More SG have appeared in diverse publications with a broader scope, concerning ship iconography (see Pryor, 1988: 25-86; Wachsmann, 1998: 123-158) or graffiti in general (Langner, 2001: 6770; Keegan, 2014: 235-236).

\section{Ship graffiti and the KARAVOI project}

On Cyprus, carved ships were found on monumental buildings dated as early as the Late Bronze Age, in Kition (Basch and Artzy, 1985) and Enkomi (Schaeffer, 1952: 102); after that period, they have been documented mainly in medieval and later contexts (Imhaus, 2001; Walsh, 2007; Trentin, 2007; Bollon and Imhaus, 2009; Trentin, 2010; Michail, 2015; Demesticha, forthcoming). Given their remarkable number and diversity, the Maritime Archaeological Research Laboratory, Department of History and Archaeology, University of Cyprus, in collaboration with the Cyprus Institute and the Department of Antiquities, initiated a research project in 2014, funded by the Leventis Foundation and entitled 'KARAVOI'" The Ship Graffiti on the Medieval Monuments of Cyprus: Mapping, Documentation and Digitisation'. The programme aimed to provide a comprehensive analysis of the SG phenomenon on the island, based on all information pertinent to SG: the ship types, their spatial arrangement in the monuments, the monuments themselves and their distribution on the island, as well as the people that incised these ships on the walls.

Although quantitative results were an important part of the KARAVOI project, they were treated with caution since graffiti are particularly vulnerable and their preservation depends on random variables. First of all, walls with preserved plaster, that is the surface where many of the graffiti were executed, are very rare in the archaeological record, especially that of antiquity; it is mainly monumental structures that preserve walls much higher than the floor level. Examples from Pompeii (Langner, 2001: 391-466), Zeugma (Benefiel and Coleman, 2013), Delos (Basch, 1985; Pomey, 1992) or Akko (Kahanov and Stern, 2008), however, show that graffiti also abounded in public spaces and on private houses, but the walls of such buildings are seldom well preserved. Perhaps this is the reason behind the very large chronological gap in the history of ship graffiti on the island, between the Bronze Age and medieval examples documented during the KARAVOI project. On Cyprus, it seems that medieval SG have been preserved mainly on religious buildings and only on those walls that were not exposed to decay or weathering, and that have not undergone major repairs; unrecorded graffiti can go unnoticed and thus be accidentally destroyed during restoration works.

Another important factor taken into consideration for data analysis was that the KARAVOI project was not extended to the occupied part of Cyprus. In our database, however, we have included some graffiti documented by others in this region (Fig. 1). Brunhilde Imhaus and the Department of Antiquities have kindly given us permission to digitize drawings of graffiti from Bellapais Abbey, the churches of Saint George of the Greeks and Saint Nicolas, in Famagusta, as well as Saint Sophia in Nicosia. In addition, photographs and drawings from two more churches from the occupied part of the Famagusta District, Saint Panteleimon and Saint Minas, were kindly given to us by Andreas Foulias and Christodoulos Christodoulou. As a result and despite our hope for a holistic approach to the shipgraffiti phenomenon on Cyprus, we have no coherent data from a considerable part of the northern and eastern parts of the island.

\section{Documentation methodology}

With the above in mind, particular emphasis was given to the programme's database, so that it could allow for a comprehensive analysis of graffiti on the island. Different forms of data have been collected, concerning everything from the ships and their types, any nonnautical graffiti found on the monuments, the buildings themselves and the wall surfaces where the graffiti are carved, as well as spatial data, both for each graffito in 


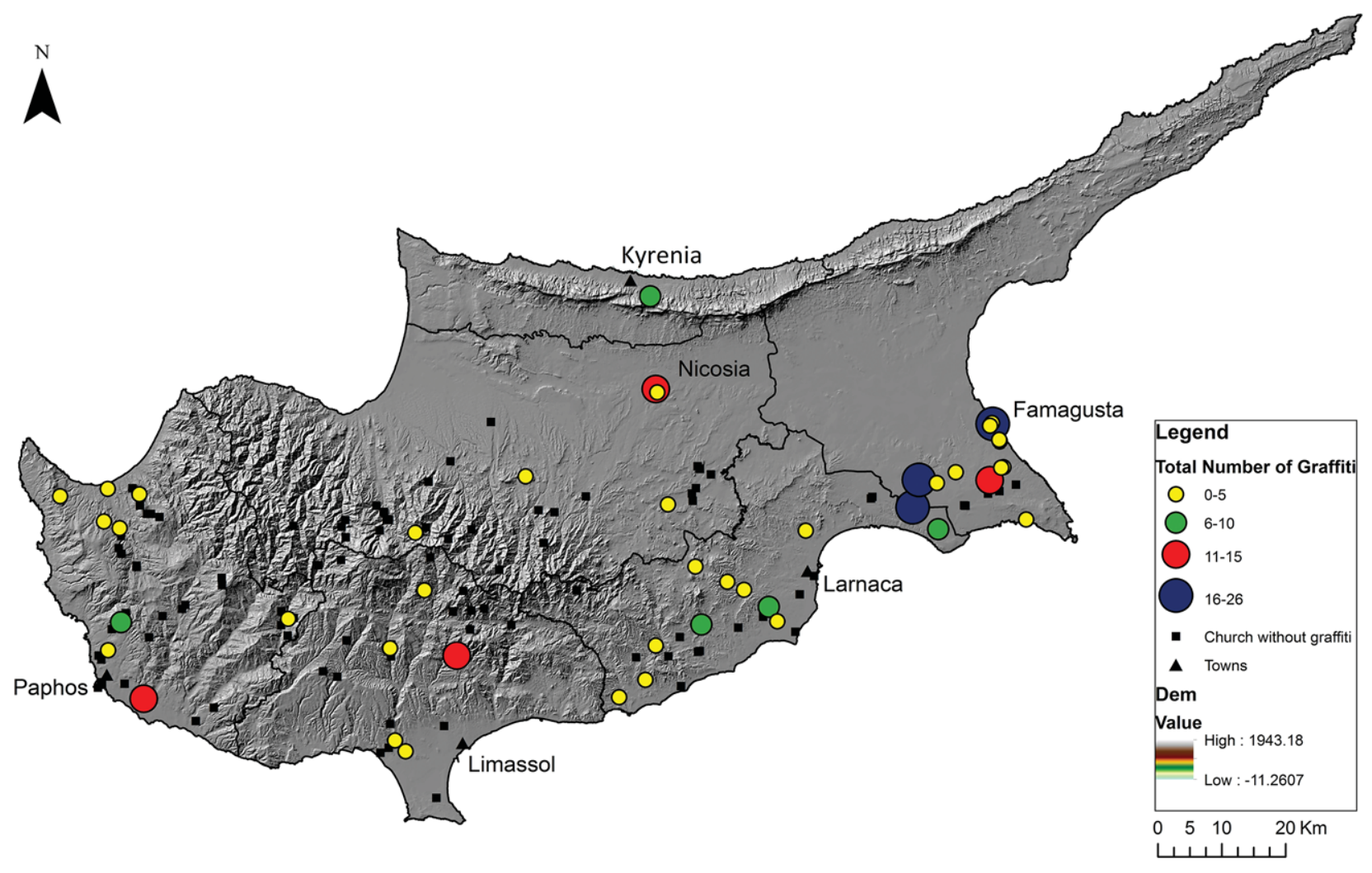

Figure 1. Map of Cyprus with the location of surveyed monuments for the KARAVOI project (Map and GIS by Niki Kyriakou, University of Cyprus).

the monument and for each graffiti-monument on the island.

Another important aspect of the KARAVOI project was the methodology followed for mapping the graffiti. Soon after the project started we realized that ship identification through graffiti is not always straightforward, not just because of the quality of the original drawings, but also because of problems in the documentation method. In order to optimize the recording process we focused on four main aspects: the lines that define its shape, the metric information, the carving quality, and the spatial context.

\section{The lines that define the SG}

When light conditions were not suitable for identifying lines on walls, aids such as flashlights were used to reveal lines otherwise hidden, but graffiti could prove hard to see on both very bright and cloudy days. Wall deterioration or cracks in the plaster can also be misleading during recording. Beyond these objective difficulties, a serious challenge is that of $a d$ hoc interpretation of what is carved and the subjective selection of lines to be recorded (see also Le Bon, 1995). An instructive example of discrepancies in SG documented by different teams was found in the Latin Chapel at the church of Panagia Aggeloktisti, in Kiti (CYP001). Graffiti of three ships have been recorded both by Demesticha in 1996 and by Imhaus (2001: 179-
180, fig.1). The differences between the two drawings (Fig. 2b, c) led the team to the decision to revisit the monument and document the graffiti with the application of Reflectance Transformation Imaging photography (RTI) (Malzbender et al., 2001; for a similar application with graffiti see Dhoop et al., 2016) (Fig. 2a). It became obvious that several details, crucial for the identification of the ship type, were not properly recorded: in 1996, not all the lines of the human figure at the stern of the ship were recorded and the line depicting a rudder was different than the actual one; the ship has an early form of a bow projection, not recorded by Imhaus and her team.

The SG drawings that were traced on film were scanned into a digital image. The scanned images were filtered to clean various dots and specks and then were converted into vector line drawings. These have smooth lines and can be scaled to any size without any loss of quality. In addition, vectors are in the native format and can be inserted without any further processing in the CAD drawings depicting the layout of the monument.

\section{Metric information}

SG size and metric information for their portrayed parts was a clear requirement of the project. The accuracy of these metrics may suffer from the curvature of the surface on which the graffito is carved. Since one cannot, a priori, assume that the surface is flat or that 
(a)

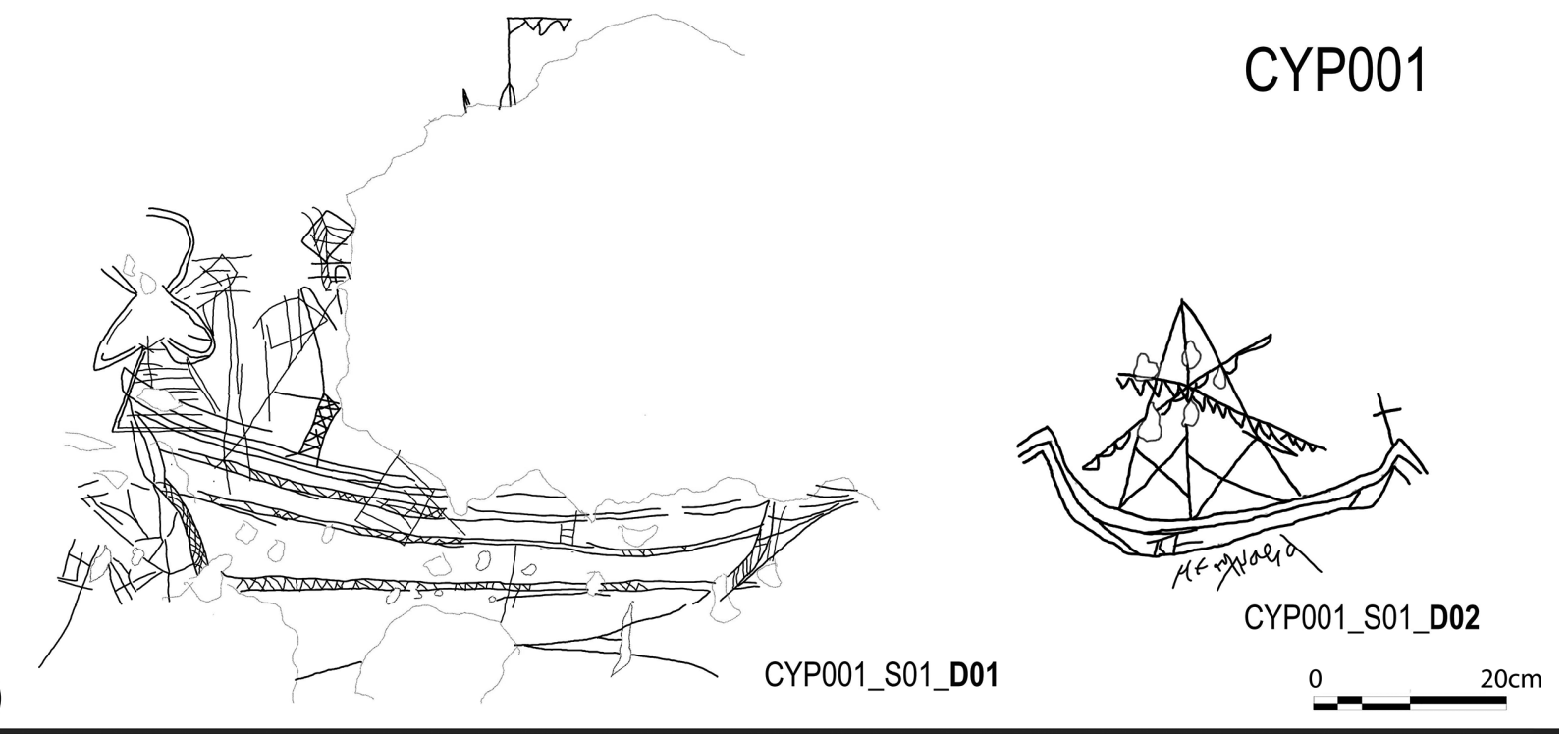

(b)

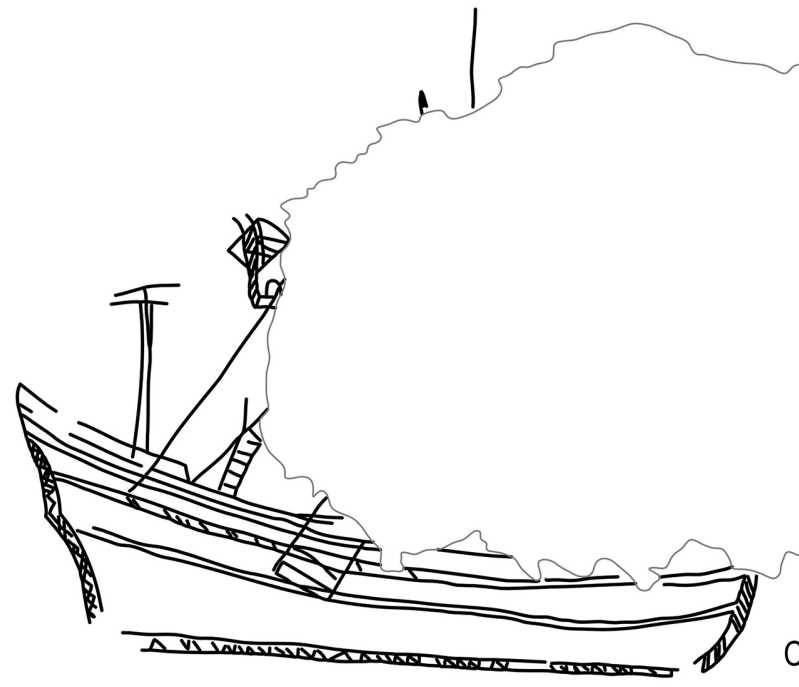

CYP001_S01_D01
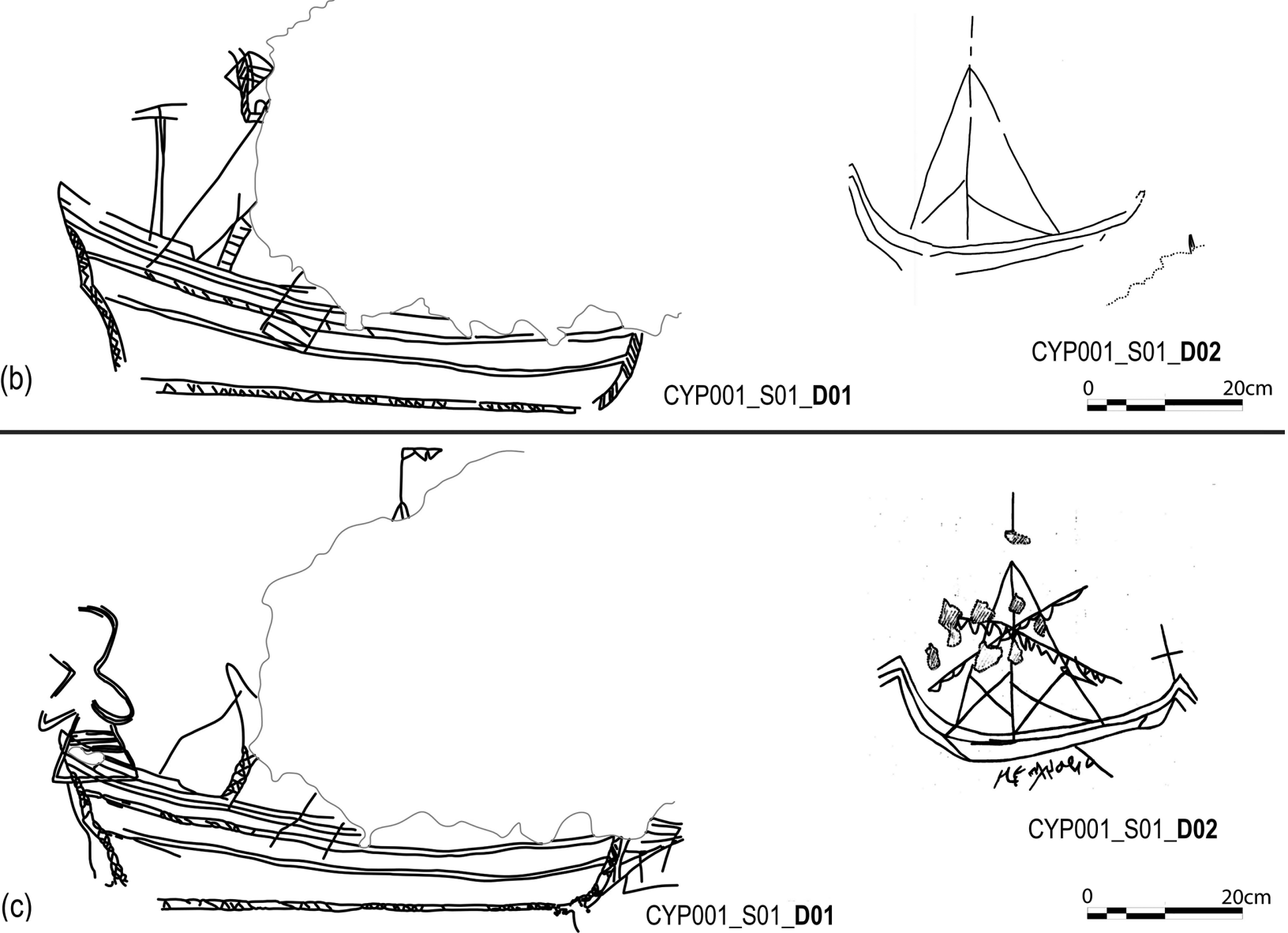

Figure 2. SG from the Latin Chapel of the Church of Panagia Angeloktisti, Kiti, Larnaca D: $a$ ) Drawings from RTI (Ropertos Georgiou, the Cyprus Institute); $b$ ) as published by Brunhilde Imhaus (2001: fig. 1); and $c$ ) as recorded by Demesticha in 1995 (Digital drawings: Lefkothea Papakosta, University of Cyprus). 


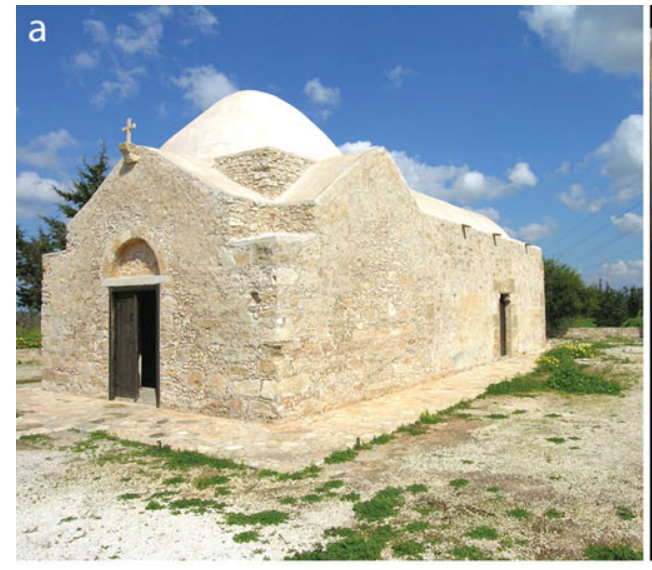

C

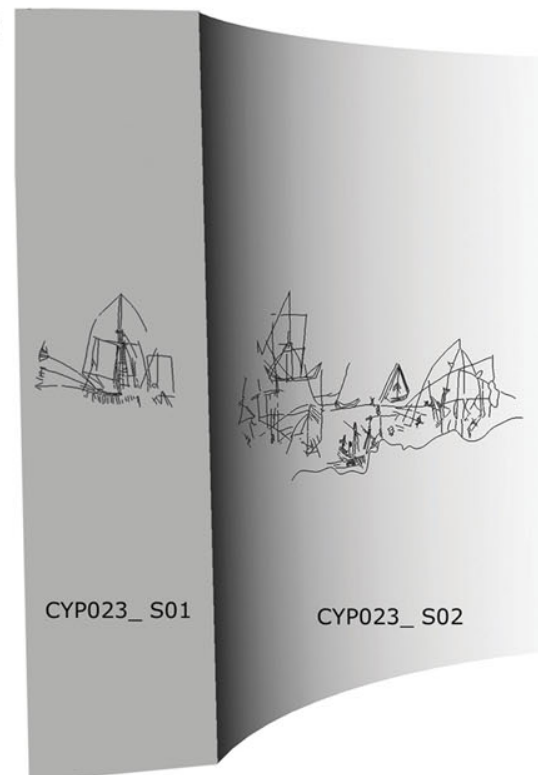

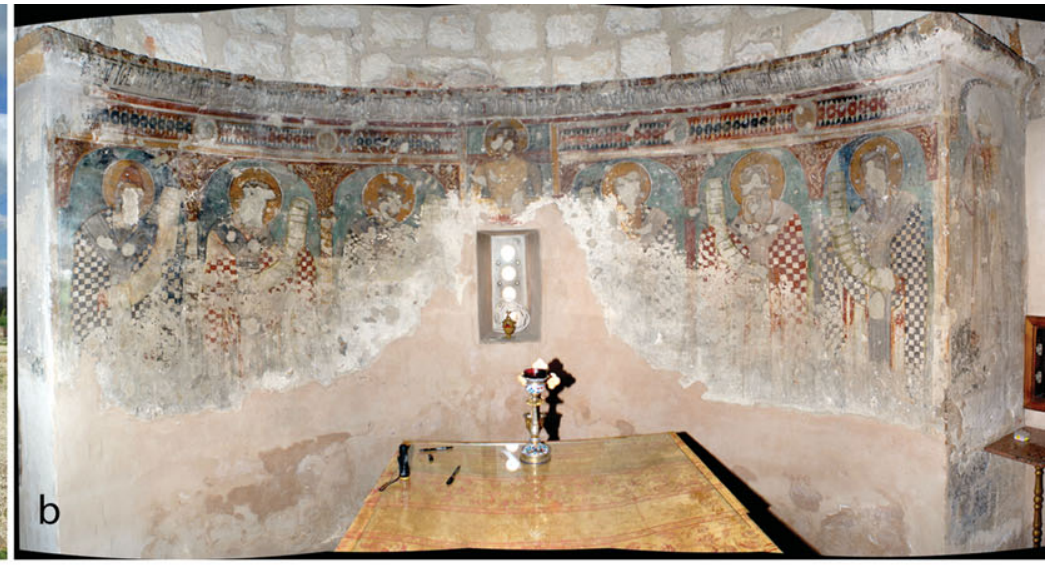

CYP023

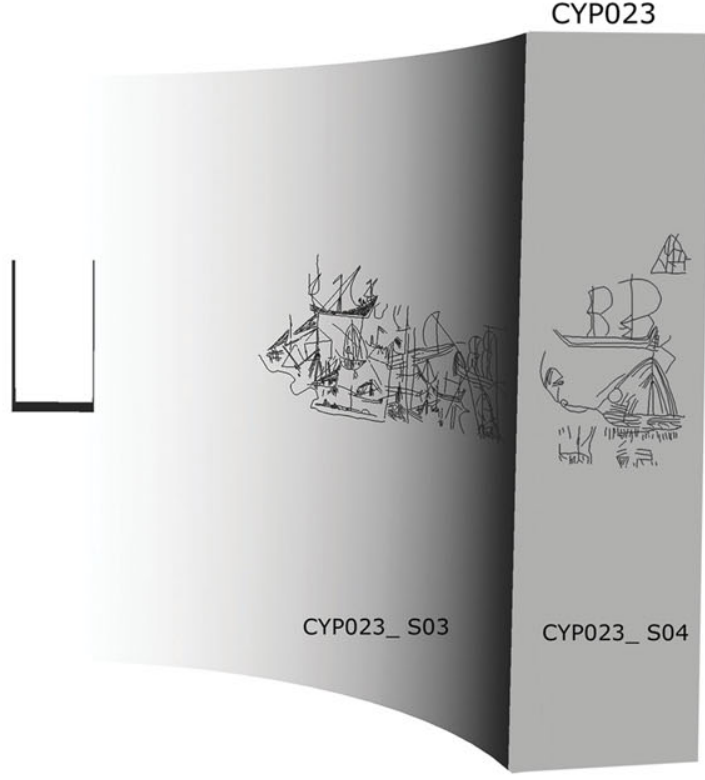

Figure 3. a) The Church Saint George of Angona, Ormidheia, Larnaca District (CYP023); b) the apse (Photomosaic: Andonis Neophytou, University of Cyprus); c) 3D reconstruction of the surfaces with SG, created by using digital photogrammetry (Irene Katsouri, University of Cyprus).

its curvature constitutes a proper geometrical shape, the easiest and most accurate method to record this is by tracing over the graffito using clear film. Metrics derived by photographic images and/or RTI cannot be relied on, because projection of any surface in $3 \mathrm{D}$ space cannot be accurately converted to $2 \mathrm{D}$ by a single photograph, and RTI for this purpose is considered a single image, since the position of the camera does not change.

\section{Carving quality}

The technique and tools used, depth and width of the incision were all recorded. For this kind of information, subjectivity of descriptions and deterioration of the surfaces deem textual accounts and micro-measurements inappropriate. On the contrary, photogrammetric processing has proven to be a means of digital documentation that can provide high levels of accuracy.

\section{Spatial information}

In order to document the position of the graffiti in the monument, especially in the cases where numerous SG were found on different walls, the published plan of the building was used where available. In two cases of unpublished churches, basic plans were produced for the needs of the spatial analysis: a 3D reconstruction of the sanctuary of Saint George of Angona (CYP023) was created using digital photogrammetry (Fig. 3); and the plan of the entire building was drawn for Saint George Teratsiotis (CYP021), using data from laser scanning (Fig. 12a). In both cases a section (slice) of the point cloud was used to create the lines required to render the model in 3D space. 
Table 1. Inscriptions and ship graffiti documented by the KARAVOI project; for Monument description refer to Appendix

\begin{tabular}{|c|c|c|c|c|c|c|c|c|c|}
\hline \multirow[b]{2}{*}{ Monument } & \multirow[b]{2}{*}{ Relation to settlement } & \multicolumn{6}{|c|}{ Ship Graffiti } & \multicolumn{2}{|c|}{ Inscriptions } \\
\hline & & Exterior & Interior & Simple & Elaborate & Uncertain & Total & Latin & Greek \\
\hline CYP001 & Outskirts village & - & 3 & - & 2 & 1 & 3 & $X$ & $X$ \\
\hline CYP002 & Country & - & 9 & 6 & 2 & 1 & 9 & - & $X$ \\
\hline CYP003 & Outskirts village & 12 & - & 5 & 1 & 6 & 12 & - & - \\
\hline CYP004 & Village & - & 2 & 2 & - & - & 2 & - & $X$ \\
\hline CYP005 & Village & 1 & 3 & 3 & 1 & - & 4 & - & - \\
\hline CYP006 & Country & - & 2 & 2 & - & - & 2 & - & - \\
\hline CYP007 & Village & - & 3 & - & 2 & 1 & 3 & $X$ & - \\
\hline CYP008 & Country & 9 & 3 & 4 & 8 & - & 12 & $\mathrm{X}$ & - \\
\hline CYP009 & Country & 4 & - & 3 & 1 & - & 4 & - & $\mathrm{X}$ \\
\hline CYP010 & Village & - & 5 & - & 2 & 3 & 5 & $X$ & $X$ \\
\hline CYP011 & Village & - & 1 & - & 1 & - & 1 & - & $\mathrm{X}$ \\
\hline CYP012 & Outskirts village & 2 & - & 1 & - & 1 & 2 & - & $X$ \\
\hline CYP013 & Urban & - & 3 & - & 2 & 1 & 3 & - & $\mathrm{X}$ \\
\hline CYP014 & Village & - & 4 & 3 & 1 & - & 4 & - & - \\
\hline CYP015 & Country & 4 & - & 1 & 1 & 2 & 4 & - & - \\
\hline CYP016 & Village & 2 & - & 2 & - & - & 2 & - & $X$ \\
\hline CYP017 & Country & 9 & - & 3 & 1 & 5 & 9 & & $X$ \\
\hline CYP018 & Country & 1 & - & - & 1 & - & 1 & - & - \\
\hline CYP019 & Country & 1 & - & 1 & - & - & 1 & - & - \\
\hline CYP020 & Village & 2 & - & 1 & - & 1 & 2 & - & - \\
\hline CYP021 & Country & - & 23 & 4 & 11 & 8 & 23 & $X$ & $X$ \\
\hline CYP022 & Village & 2 & 2 & 2 & 2 & - & 4 & - & $X$ \\
\hline CYP023 & Country & - & 23 & 9 & 6 & 8 & 23 & - & $X$ \\
\hline CYP024 & Country & 5 & - & 5 & - & - & 5 & $X$ & $X$ \\
\hline CYP025 & Village & - & 1 & - & 1 & - & 1 & $\mathrm{X}$ & $\mathrm{X}$ \\
\hline CYP026 & Village & 3 & - & 2 & - & 1 & 3 & - & - \\
\hline CYP027 & Country & 1 & - & 5 & 1 & 5 & 11 & - & $X$ \\
\hline CYP028 & Country & - & 7 & 2 & 5 & - & 7 & $X$ & $\mathrm{X}$ \\
\hline CYP029 & Urban & - & 26 & 7 & 14 & 5 & 26 & $X$ & $X$ \\
\hline CYP030 & Country & - & 1 & 1 & - & - & 1 & $X$ & $X$ \\
\hline CYP031 & Country & - & 1 & 1 & - & - & 1 & - & $X$ \\
\hline CYP032 & Outskirts & - & 9 & 2 & 5 & 2 & 9 & - & $\mathrm{X}$ \\
\hline CYP033 & Country & - & 1 & - & - & 1 & 1 & - & - \\
\hline CYP034 & Country & - & 2 & - & 2 & - & 2 & - & - \\
\hline CYP035 & Urban & - & 11 & 3 & 6 & 2 & 11 & $X$ & - \\
\hline CYP036 & Urban & - & 3 & - & 3 & - & 3 & - & $X$ \\
\hline CYP037 & Country & 2 & - & - & - & 2 & 2 & - & - \\
\hline CYP038 & Village & 2 & - & 2 & - & - & 2 & - & $\mathrm{X}$ \\
\hline CYP039 & Outskirts village & 1 & - & - & 1 & - & 1 & - & - \\
\hline CYP040 & Village & 6 & - & 2 & 2 & 2 & 6 & - & $\mathrm{X}$ \\
\hline CYP041 & Village & 1 & - & 1 & - & - & 1 & - & - \\
\hline CYP042 & Urban & - & - & - & - & - & - & - & - \\
\hline CYP043 & Country & - & 1 & - & - & 1 & 1 & - & - \\
\hline CYP044 & Country & - & 4 & 1 & 1 & 2 & 4 & - & - \\
\hline TOTAL & & 80 & 153 & 86 & 86 & 61 & 233 & & \\
\hline
\end{tabular}

\section{The ships}

Based on their significance as sources for ship iconography, three main groups of SG were distinguished: uncertain; simple drawings with masts and some rigging elements; and elaborate ships (Table 1). Similar groups were distinguished by Goudas (1912: 335 ) for the 22 SG he documented from Thesseion, Athens.

\section{Uncertain ship graffiti}

The first group is comprised of roughly executed drawings, and it is often dubious if they depict ships, either because of the quality of the drawings or because of their poor preservation. They make up a significant percentage of the recorded SG (60 of 233, 25.7\%) and were documented during the KARAVOI project not as sources of nautical iconography but as indicators of the extent and the nature of the SG practice 

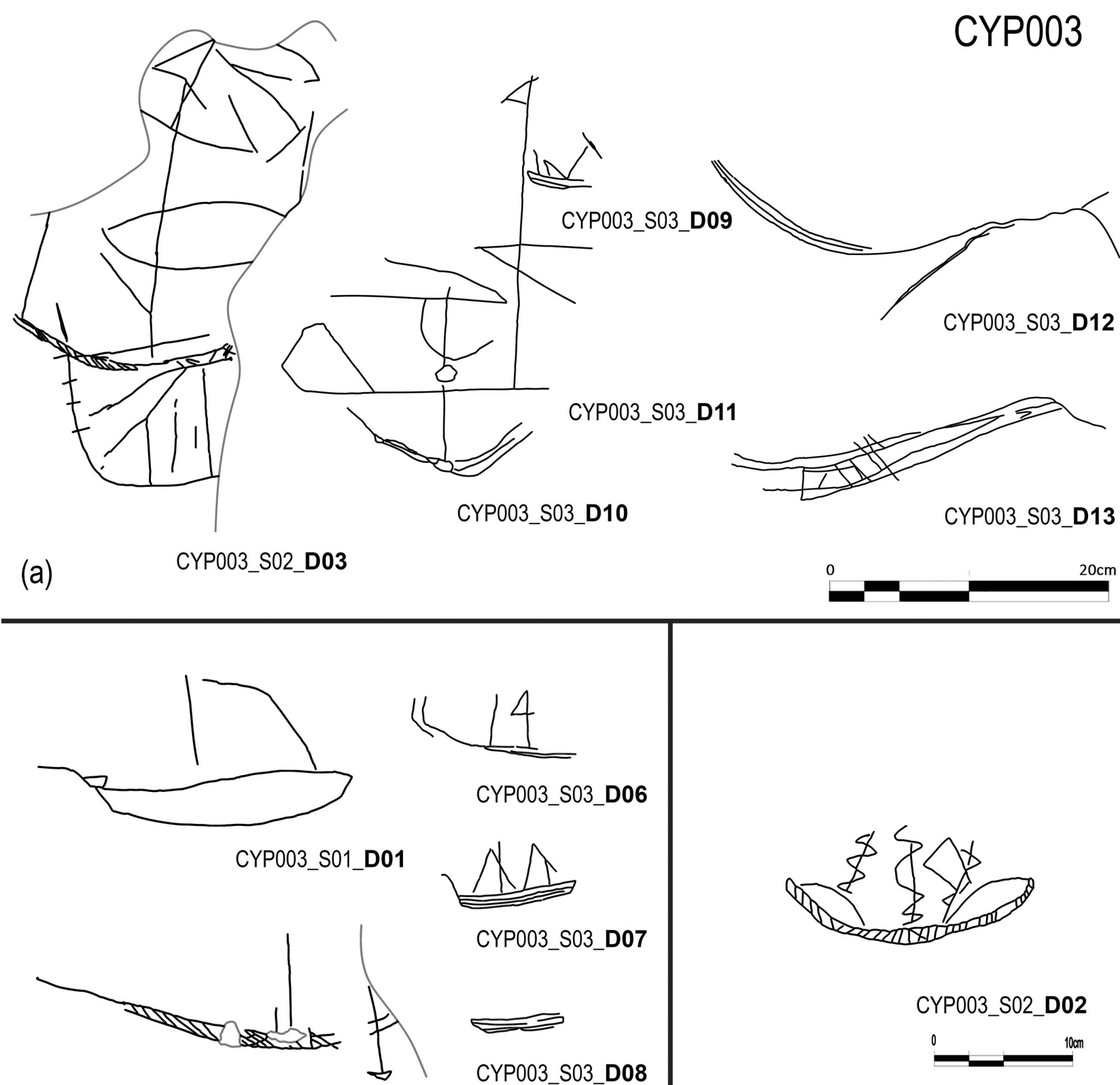

CYP003_S03_D07

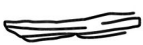

CYPO03_S03_D

CYP003_S03_D05

(b)
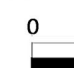

Figure 4. SG recorded on the exterior walls of the Church of Saint George, Acheleia, Paphos District (CYP003): $a$ ) Uncertain b) Simple: and $c$ ) Elaborate (Digital drawings: Lefkothea Papakosta, University of Cyprus).

in certain monuments: for example in Saint George, Acheleia, Paphos D (CYP003), half of the documented SG (6 out of 12) are uncertain (Fig. 4a). The fact, however, that they were found in close proximity with clearly defined SG may be indicative of an effort to draw ships by less skilful carvers (Fig. 4b, c). This is possibly the reason why uncertain SG were always found along with simple or elaborate ones; in other words, no graffiti-monuments were recorded with only uncertain SG.

\section{Simple ship graffiti}

Simple ship drawings depicting one- or two-masted coasters (Fig. 4b, 5, 10f-h) comprised the largest 
Table 2. The distribution of ship graffiti types per (modern) district

\begin{tabular}{lllll}
\hline District & Simple & Elaborate & Uncertain & Total \\
\hline Kyrenia & 2 & 5 & 0 & 7 \\
Nicosia & 7 & 8 & 3 & 18 \\
Limassol & 10 & 4 & 7 & 21 \\
Paphos & 19 & 6 & 9 & 34 \\
Larnaca & 27 & 21 & 21 & 69 \\
Famagusta & 22 & 42 & 20 & 84 \\
Total & 87 & 86 & 60 & 233 \\
\hline
\end{tabular}

group of documented SG (87 out of $233,37.3 \%$ ) (Table 2). They present significant diversity regarding their drawing quality, and it is often impossible to date or identify the type of the ships depicted, which are drawn with simple lines shaping the hull, the masts and the rigging. Simple ships are the most common type of SG and are known from diverse contexts in the Mediterranean: for example CYP005_S01_D03, a simple SG from Panagia Chryseleousa, Emba (Fig. 5f) is very similar to a simple ship from the 15thcentury Castello di Giulio II, Ostia (Boetto 2002: fig. 9), but another from Archangel Michael, Monagri, CYP009_S01_D01 (Fig. 5b) presents similarities with an ancient SG from Dura Europos (Langner 2001: 413, no 1955). Simple SG are not described in detail here, but are fully included in the spatial analysis of the Cypriot SG.

\section{Elaborate ship graffiti}

Special emphasis is given to the third group of elaborate ship graffiti ( 86 of $233,36.9 \%$ ) (Table 2 ). The details in these drawings indicate that the carvers tried, more or less successfully, to depict construction details or important nautical elements of the ship's gear or rigging. Seven such SG have already been published and thus are not discussed in detail in this study, although they are included in the KARAVOI catalogue (see Appendix). These are: two SG depicting an Ottoman galliot (Fig. 6a) and a saika, from Selimiye mosque (or the old Cathedral of Saint Sophia in Nicosia) (CYP035) (Bollon and Imhaus, 2009: 425-426); three SG depicting two brigs (Fig. 6b) and one three-masted ship (Fig. 6c) from the Church of Saint George of the Greeks (CYP029) (Imhaus, 2001: 182-183; Walsh 2007; Michail 2015: 45); and finally a possible depiction of a 16th-century fragada (Fig. 6d), from the Royal Chapel of Saint Ekaterina (CYP010) (Bollon and Imhaus, 2009: 426).

Not all of the elaborate SG can provide conclusive typological information, although in most cases the carver clearly intended to depict details of a specific ship. Most of them were found on the monuments of Famagusta and Larnaca Districts (D) (63 of the 86 elaborate SG of the catalogue, Table 2), and the six most comprehensive of them have been chosen for discussion in this paper.
Each SG is tagged with a code, consisting of the monument identifier (CYP001-), the number of the surface or the wall that the SG is carved on (S01-), and the code number of the SG itself (D01-). Each SG is discussed under the graffiti-monument where it was found. The full code is written at first mention, and the SG code number (D01-) only thereafter.

\section{CYP001}

Latin Chapel of the Church of Panagia Angeloktisti, Kiti, Larnaca District (Stylianou and Stylianou, 1985: 49-51; Foulias, 2004; der Parthog, 2006: 298-300).

The Church of the Panagia Angeloktisti, a cross-insquare, domed building, was built in the late 11th century on the ruins of a 4th-6th-century basilica, incorporating the eastern apse of the earlier structure. The Latin Chapel was attached along the southern side of the existing church building in the 13th or the early 14th century, almost certainly by the Gibelet family (Fig. 7a).

Imhaus (2001: 179-180, fig. 1) published two ships on a wall plastered 'during the Ottoman period', which was revealed during the restoration works by the Department of Antiquities in 1967. The same ships, documented also by S. Demesticha and Y. Vichos in 1995, were recorded a third time during the KARAVOI project using RTI (Fig. 2c).

CYP001_S01_D01 (Fig. 7b) is a depiction of a merchantman with a straight keel. The stem is slightly curved and the sternpost stepped and possibly higher. Both posts, as well as the rest of the main ship elements - the keel, the gunwale, and the wales - are drawn with double lines. Above the gunwale and to the left, a light superstructure is depicted. The lines of the gunwale, the stem, and the wales are prolonged to the right, shaping a beak-head. Some lines left of the sternpost could be associated with the rudder, although they are thinner and shallower than the rest of the SG lines. Over the stern a human figure, possibly female, in a praying position, is depicted. Above the hull the wall is damaged so most of the rigging depiction is lost. Above the damaged area, however, the top of one mast with a flag is preserved. Just above the aft part of the gunwale, an oblique band filled with parallel lines may represent the lower part of the rigging. The type of the ship cannot be defined with certainty, mainly because the rigging is missing: the hull presents similarities with lontra or saika, both 17th-18th-century types (Damianidis and Delis, 2014), although the stern differs from the 'londra' illustrated by Dummer (1685).

CYP001_S01_D02 (Fig. 7c) illustrates a one-masted vessel, with three parallel lines forming the outline of a hull with high extremities. The left end is higher and both ends give the impression of uncommon features. A vertical line, representing the central mast, is located a little forward of midships to the left. Two lines starting from the top of the mainmast probably represent the rigging. There are two crossed yards, both 
carrying furled sails. Under the keel, the only maritime inscription found thus far was recorded; it is written in Greek: $\mu \varepsilon \pi \lambda \eta \dot{\alpha} \rho \iota \alpha$ ('with small ships').

These two ships might have been made by different carvers, at different times. D02 is hard to date but D01 has features datable to the 17th-18th centuries. Moreover, based on palaeographical analysis and the dates themselves, a similar date can be suggested for several Greek and Latin inscriptions, some scratched and some traced with black colour, found on the same wall and on the marble imposts of the arch connecting the chapel with the church.

\section{CYP011}

\section{Church of Saint Antony, Kellia, Larnaca District.}

This cross-in-square church was built in the 10th century on the remains of an older, three-aisled basilica. The present apse and high transept vault were added in the 15th century (Stylianou and Stylianou, 1985: 433-437; der Parthog, 2006: 312-313; Foulias, 2011: 171-178, 375-378). The dipinto of a ship with several inscriptions was recorded on a marble ashlar block built into the south side of the north-western pillar, which belongs to the earliest phase of the building (Fig. 8a, CYP011_S01_D01).

A long ship, with straight keel and rounded ends, is depicted in red. No specific ship type or dating can be suggested with certainty because the dipinto is not well preserved, and much information is missing, but its galley-ship characteristics are clear. Two pairs of oblique lines at the lower part of a probable mast, may depict the rigging. The hull is simply drawn; a triangle at the bow, to the left, is probably a kind of construction connected with it. The form of the side rudders, to the right, with a long shaft and a triangular short blade, is rather uncommon. The square depicted on the upper part of the stern could be either a superstructure or a flag. Two oblique lines under the keel may represent oars. There is a Greek inscription under the keel, which is too poorly preserved to read. The same is the case for the other Greek inscriptions in the church, one painted on the north-eastern pillar and some carved on the pillars and the apse of the sanctuary (Trentin 2010: 307).

\section{CYP008}

Church of Saint Marina. Frenaros, Famagusta District.

This single-aisled barrel-vaulted rural church is dated to the 15th or 16th century (der Parthog, 2006: 325) (Fig. 9). A total of $12 \mathrm{SG}$ were recorded, eight elaborate and four simple. All simple SG, three on the external northern wall (Fig. 10f-h) and one on the external western wall (Fig. 11d) are much smaller in size than the rest.

The five elaborate graffiti on the external northern wall (Fig. 10a-e) have been designed in a line, one next to the other: four of them have their bows facing towards the east but one, in the centre, faces the opposite direction. The three elaborate $\mathrm{SG}$ on the interior north wall (Fig. 11a-c) are also in line, with their bows turned to the east.

All eight elaborate SG depict sailing boats with one or two masts and are discussed as a group because they present typological similarities. In five cases, the stern rudder is depicted as a rectangle, parallel to the sternpost (CYP008_S01_D01, D02, D03; CYP008_S03_D09, and CYP008_S02_D10) (Figs. 10ac, 11a,c). Parallel lines within the rectangles possibly represent the pintles and gudgeons with which the rudders were affixed. In three cases the tiller is depicted at a slight angle above the stern rudder and drawn within the lines indicating a superstructure (D01, D03 and D09)(Figs 10a, c, and 11a). The rudder, however, is clearly extended beneath the keel in three cases (D01, D03 and D09), which is unusual for merchant ships and especially for those without a curved sternpost (for parallels see Ray, 2001: figs 59 and 69).

A rectangle is carved at an angle over the stern castle of six ships (D01-D04, D09, and D10) (Figs 10a-d, $11 \mathrm{a}, \mathrm{c})$. Filled with vertical and horizontal lines in a chequered pattern, it probably represents an awning, made of a light wooden construction with closely lying spars (Ray, 2001: 77). This is a common feature in different types of ships such as carracks, caravels or galleys of the 14th century (see for example Landström, 1961: 262, fig. 26).

The hulls of ships D01, D02, and D09 have a similar form, which gives the impression of narrow but robust ships (Figs 10a, b, 11a). Only D01 has two masts. The central one is placed vertically amidships, just in front of the aft castle. The foremast, on the bow, is shorter and carries a square sail, filled with a chequered pattern. This is a common way of depicting pieces of cloth sewn together; lateen sails, by contrast, are often shown with elongated rectangular sections (see for example Ray, 2001: figs 18, 25 and 67). There is no depiction of a yard, sail or crow's nest. D02 and D09 show only one mainmast, positioned again just in front of the aft castle; in both cases, the sails are furled on the yards, which are depicted with oblique lines. Forestays and shrouds are clearly carved. The inclination and the length of the yards could suggest lateen sails. Only D02 is depicted with an anchor; apparently a kind of grapnel that hangs from the bow. In D01 the small lines under the keel probably reflect the sea; compare, for example, the 16th-century model of a sailing boat with no oars in the Madrid Naval Museum (Landström, 1961: fig. 286).

Ships D01, D03 and D09 each have a straight keel. An oblique line running from the edge of the keel illustrates the stem, but the sternpost is depicted with a straight line. The fore and aft castles are represented as rectangles with a gap in between. These superstructures do not extend beyond the bow as is the case of carracks, and it seems more plausible that they depict extensions of the deck and the bulwarks, or even a balustrade. 


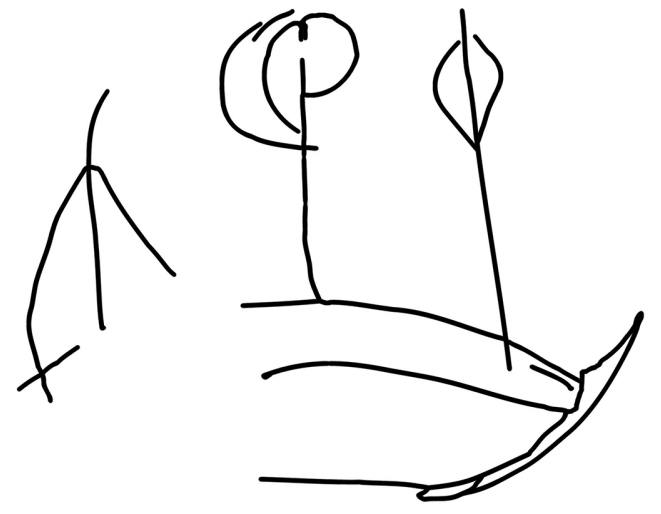

(a) CYP002_S01_D07

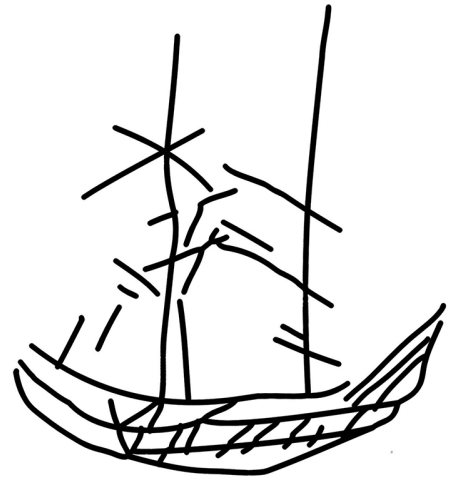

(e) CYP027_S02_D02

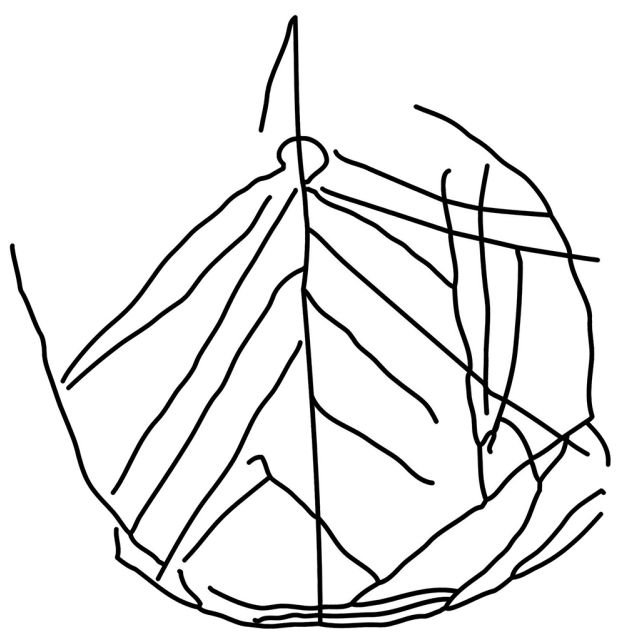

(b) CYP009_S01_D01

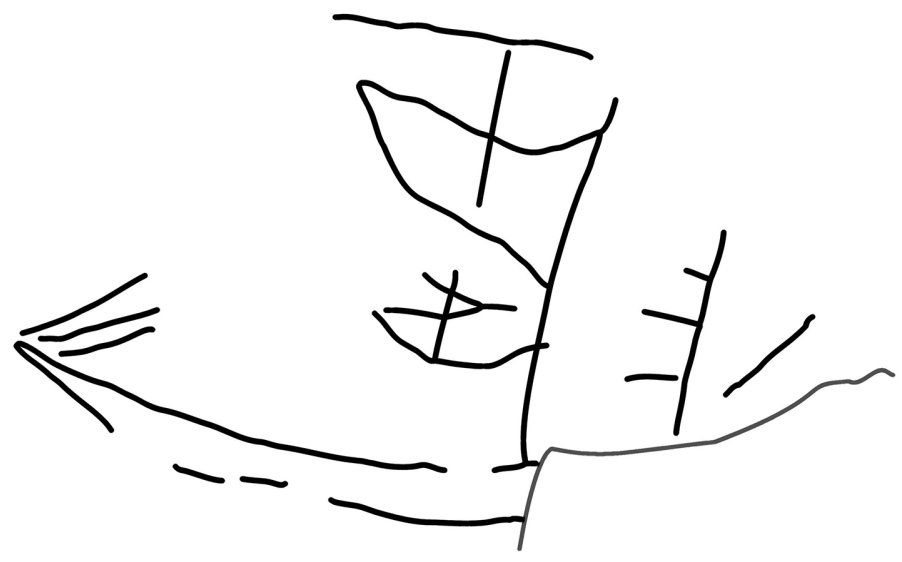

(c) CYP014_S01_D02

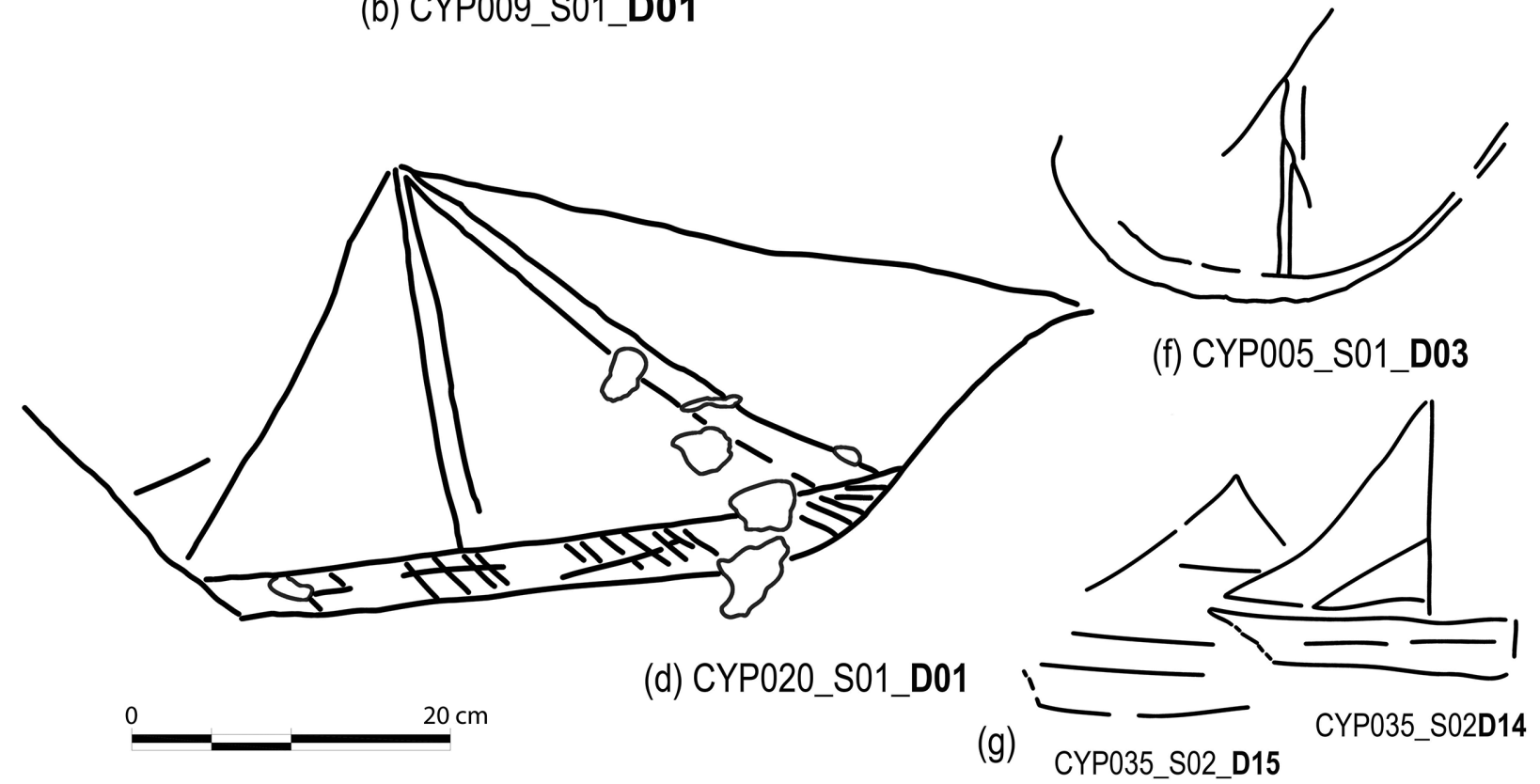

Figure 5. Simple SG from: a) Palaea Enkleistra of St Neophytus, Souskiou, Paphos D; $b$ ) Church of Archangel Michael, Monagri, Troodos, Limassol D; c) Church of Saint Marina, Mari, Larnaca D; d) Church of Panagia, Deryneia, Famagusta D; e) Church of Panagia Amirou, Apsiou, Limassol D; f) Church of Panagia Chryseleousa, Emba, Paphos D; $g$ ) Selimiye Mosque (Old Cathedral of Saint Sophia), Nicosia D (Digital drawings: Lefkothea Papakosta, University of Cyprus). 

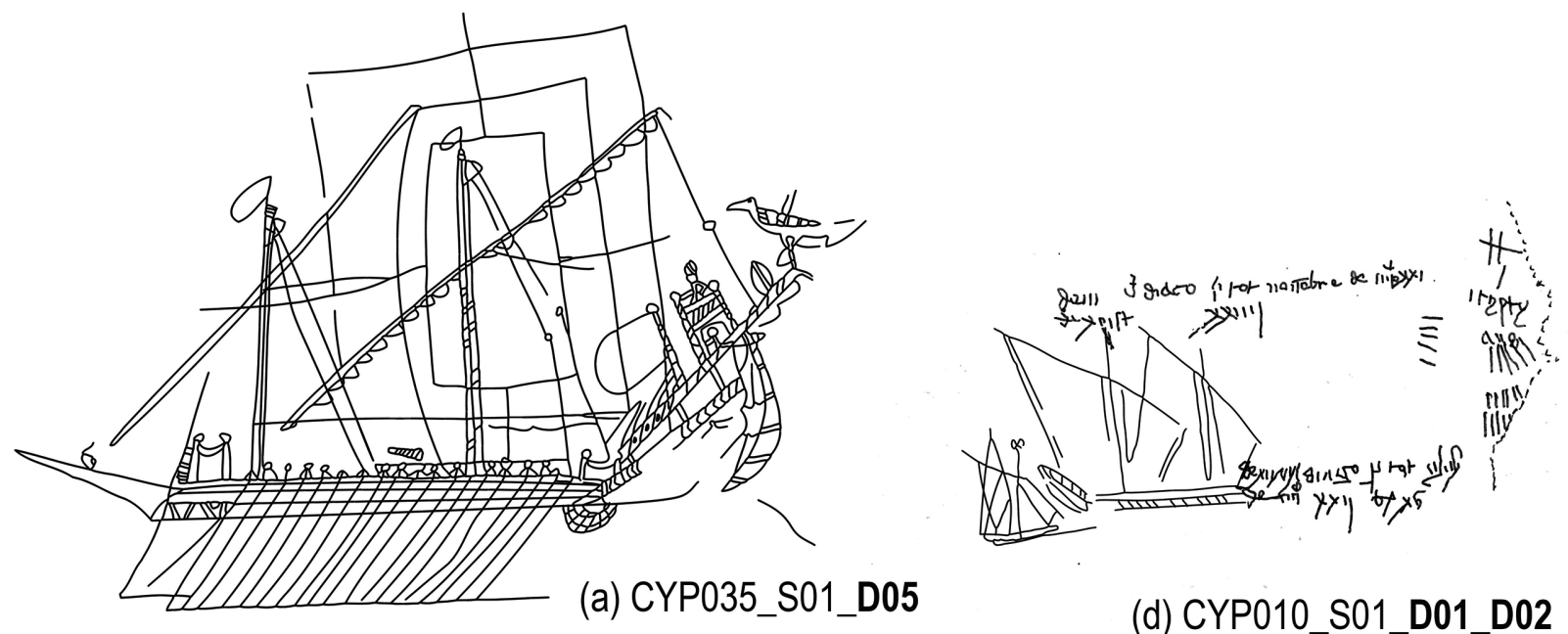

(d) CYP010_S01_D01_D02
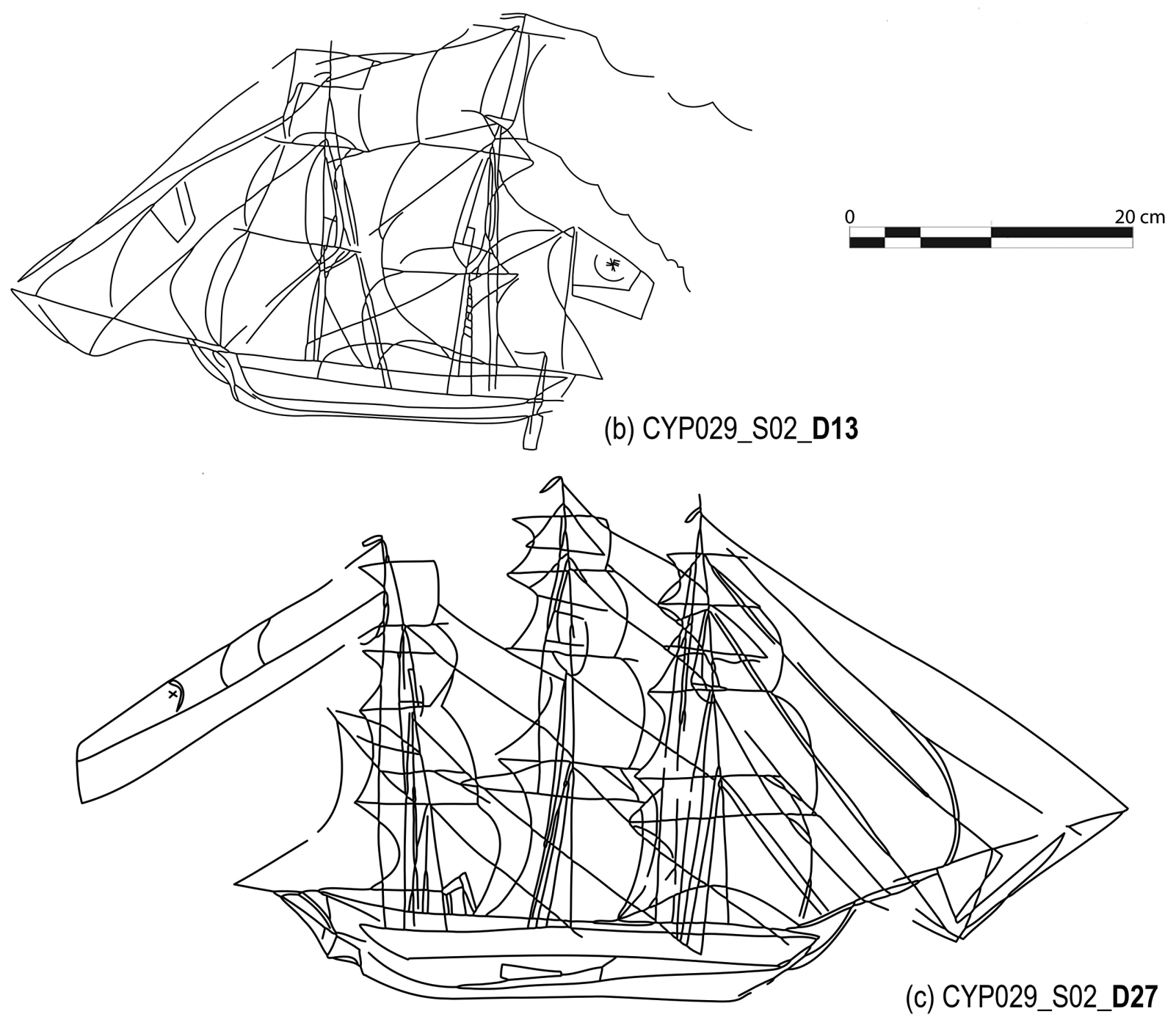

Figure 6. Previously published elaborate SG from Cypriot monuments: a) Selimiye mosque (old Cathedral of Saint Sophia in Nicosia), as published by Bollon and Imhaus (2009: 425-426); b) and c) Church of Saint George of the Greeks, Famagusta District (see Imhaus, 2001: 182-183; Walsh, 2007; Michail, 2015: 45); d) 'Royal Chapel' of Saint Catherine, Pyrga, Larnaca District, previously published, without the inscription, by Bollon and Imhaus (2009: 426) (Original drawings by Jean Humbert, reproduced with the permission of Brunhilde Imhaus. Digital processing: Lefkothea Papakosta, University of Cyprus). 
(a)

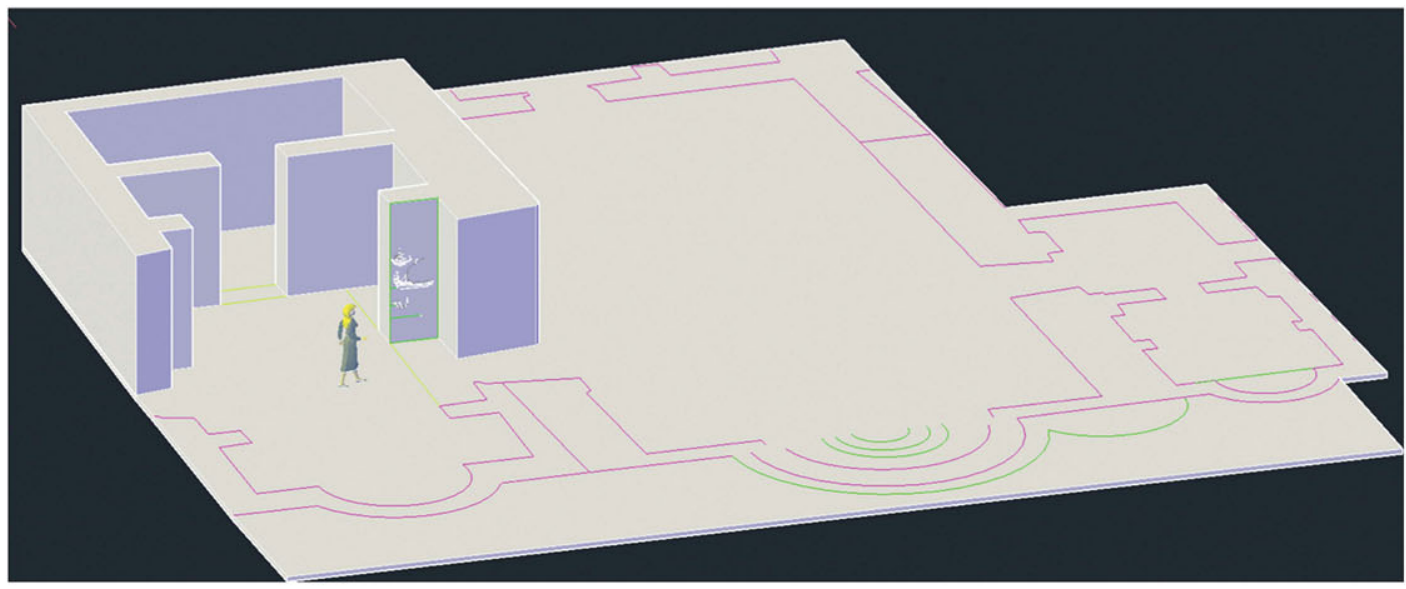

(b)

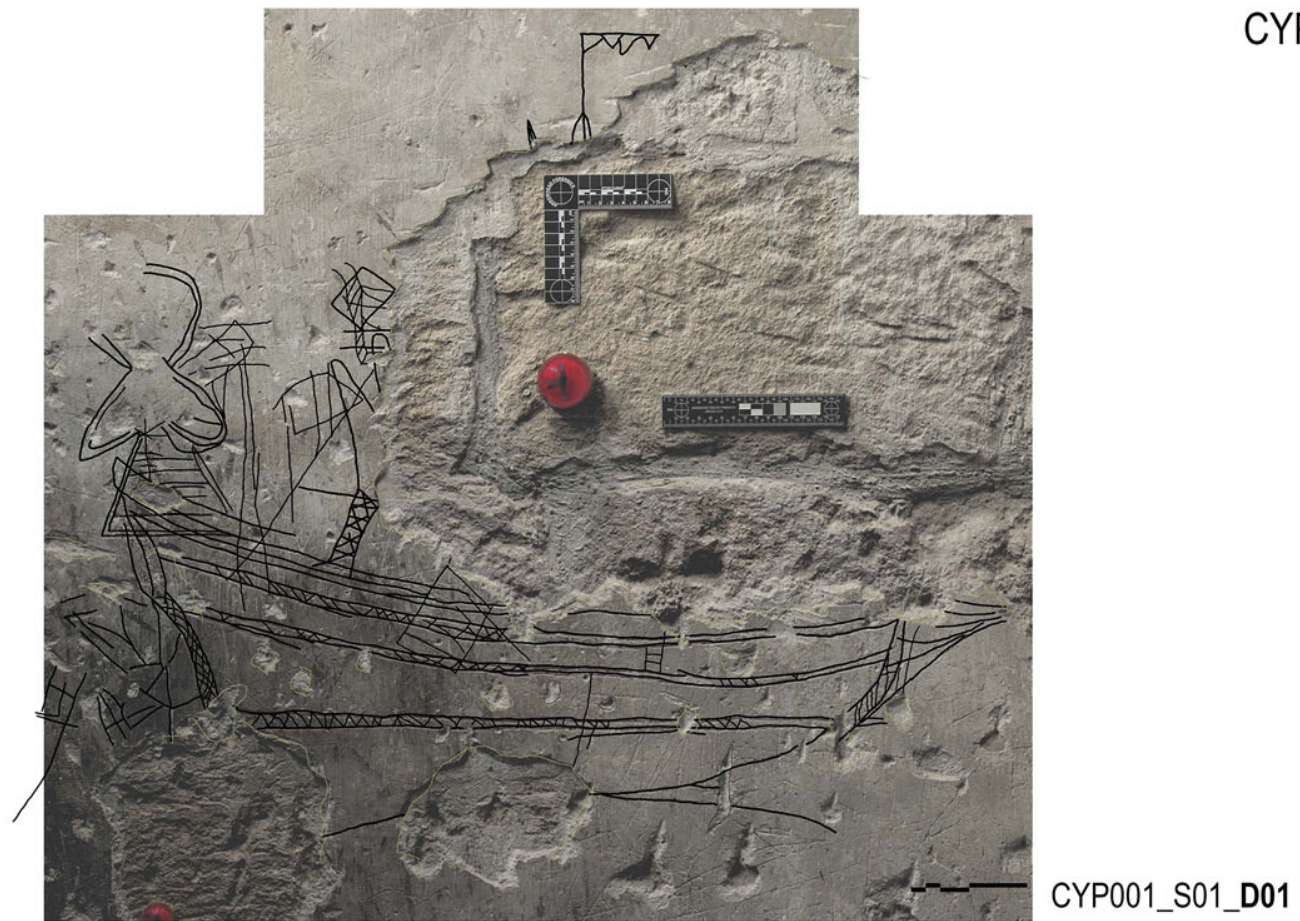

CYP001

(c)

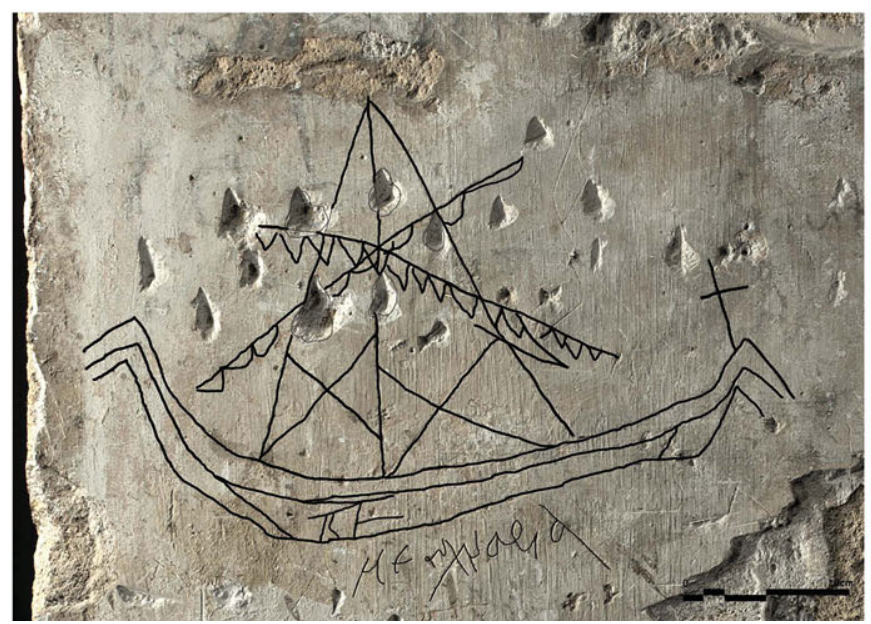

CYP001_S01_D02

Figure 7. a) The location of the SG in the Latin Chapel, adjacent to the Church of Panagia Aggeloktissti, Kiti (CYP001) (3D plan, Lefkothea Papakosta, University of Cyprus); b) and $c$ ) SG traced on the surfaces, documented by RTI (RTI, Ropertos Georghiou, Cyprus Institute; Tracing, Lefkothea Papakosta, University of Cyprus). 

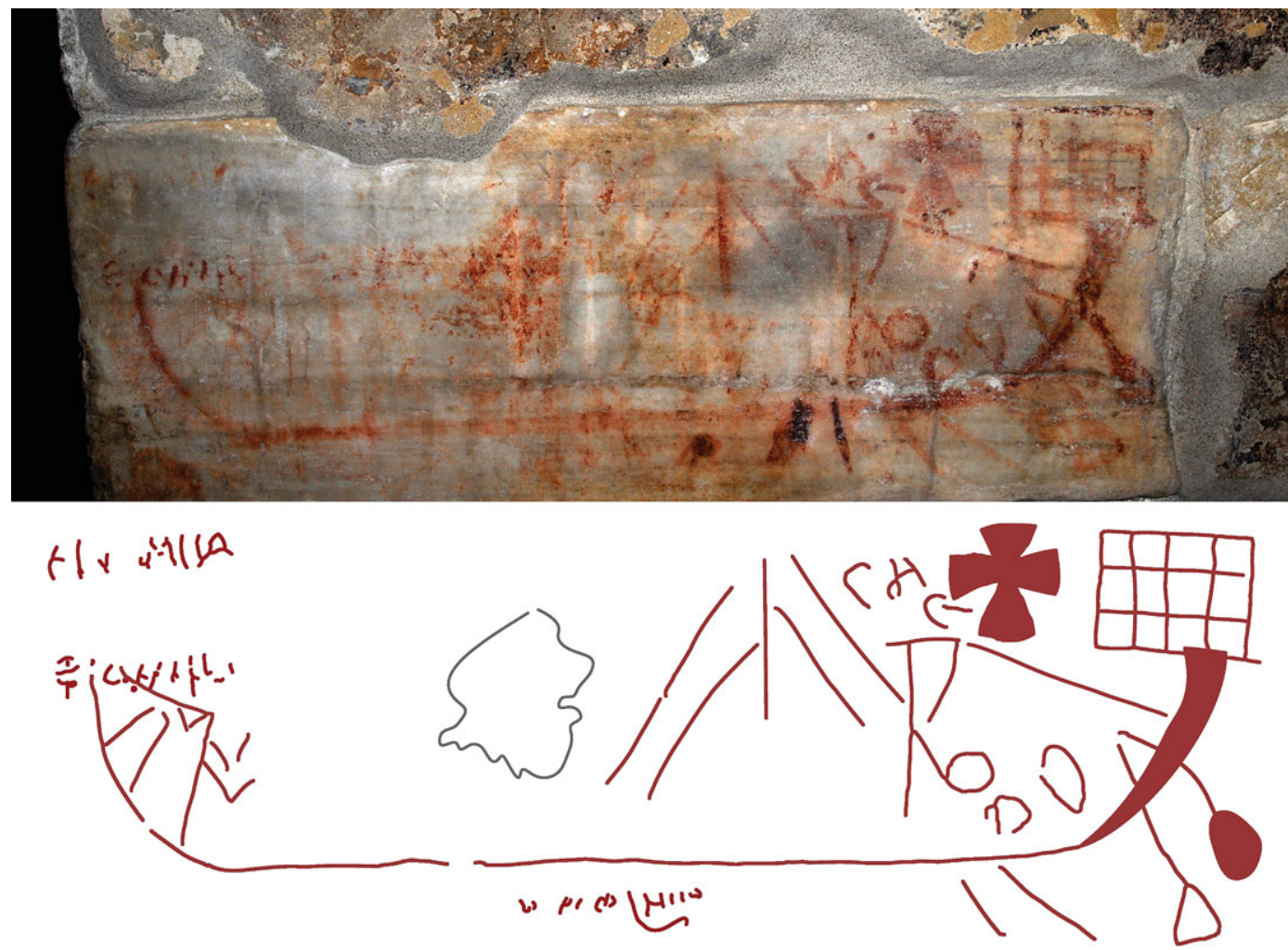

CYP011_S01_D01

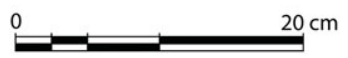

Figure 8. The ship dipinto from the Church of Saint Antony, Kellia, Larnaca D (Photograph: Andonis Neophytou, Digital drawing: Lefkothea Papakosta, University of Cyprus)

On the hulls of all the ships in this group, a number of horizontal lines can be observed portraying the planking strakes. They run directly from the stem to the sternpost. On D09 there are possibly some vertical reinforcements. The bow projection on D01, D02, D05, and D09 is formed by a slanting line from the fore end of the keel and a horizontal one that continues the sheerstrake. The second strake from the top penetrates this part and could depict a wale. The bow projection is not high and resembles a ram rather than a beak-head of the 17 th century.

All the above lead us to believe, with certain reservations, that these $\mathrm{SG}$ reflect characteristics of an early example of a 16th-century galleon, especially as far as the hull is concerned (Landström, 1961: 113). The origin of the vessel type is obscure, but we know that it had spread very quickly to many places, such as Spain, England, and Italy, by the middle of the 16th century.

Although D10 is not well preserved, some similarities with D01, D02 and D09 can be observed, concerning the shape of the hull. It has only one mast, placed vertically amidships, with no depiction of a sail. The slope of the yard may suggest a lateen sail. Just above it, a semi-circular sketch may indicate the crow's nest, whence eight oblique lines, reflecting the rigging, run to the bow and stern of the vessel.
D03 depicts a ship with a straight stern and a slightly inclined bow. Its single mast is stepped vertically fore of midships and it runs through the entire hull. Three lines, probably representing the rigging, run from the top of the mast - two towards the bow and one to the stern. The hull shape gives the impression of a high-sided ship, with at least five lines representing the planking; if so, the strakes end at the stem. Narrow rectangles are used to depict fore and aft castles or a balustrade.

At the beginning of the 14th century, northern cogs were introduced in the Mediterranean and by the second half of the century the cog was being built in the frame-first tradition (Bonino, 1978). In the same period, the term cocha became the Mediterranean equivalent of the northern European cog, commonly used for large round ships with a single square sail and a stern rudder. The hull shape of the merchant ship depicted in D03 (Fig. 10c) reflects characteristics of a $\operatorname{cog}$ (Landström, 1961: figs 186, 187) but it is hard to tell if this is a late survival of an old type or not as long as it remains uncertain if the church dates to the 15th or the 16th century (der Parthog, 2006: 325).

D04 (Fig. 10d) also illustrates a one-masted ship, unless the vertical lines in the bow represent a second mast. As in D03, the central mast, a vertical line amidships, runs almost through the hull. The rigging is 


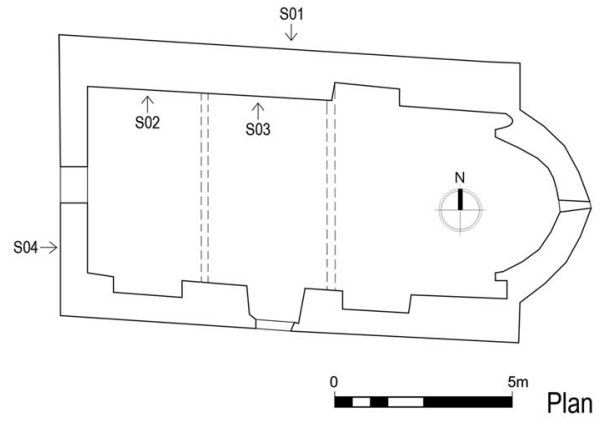

CYP008
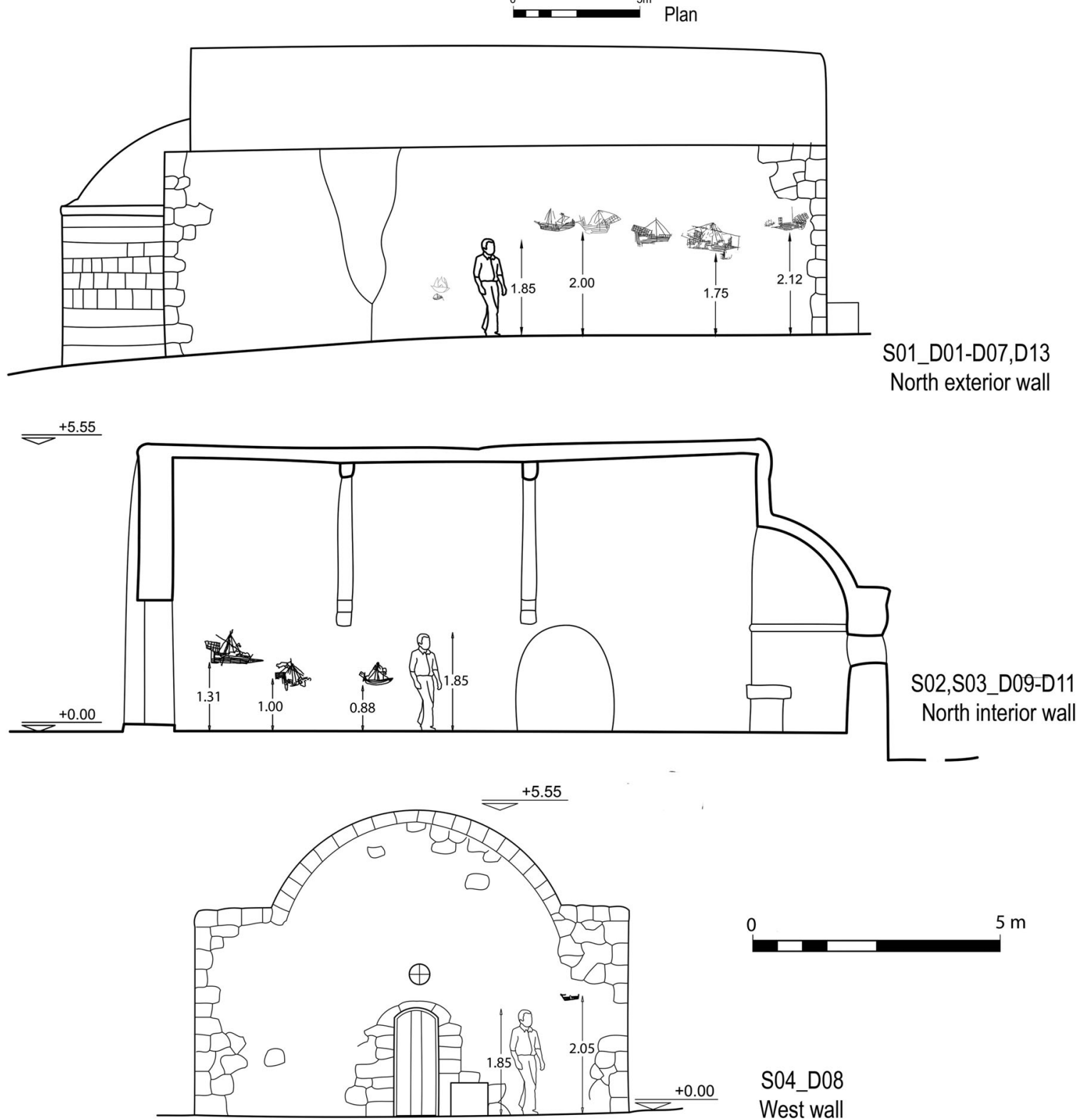

Figure 9. The location of the SG on the walls of the Church of Saint Marina, Frenaros, Famagusta D (CYP008). (Drawing: Lefkothea Papakosta)

shown with lines from the top of the mast running fore and aft. The ship appears to be a carrack (Landström, 1961: fig. 248; Ray, 2001, fig. 122) with the forecastle and the sterncastle integrated into the lines of the hull. Horizontal lines on the hull indicate strakes. The narrow oblique rectangle aft of midships, behind the central mast, could represent either support for the awning or a gun (for early depictions of guns in 

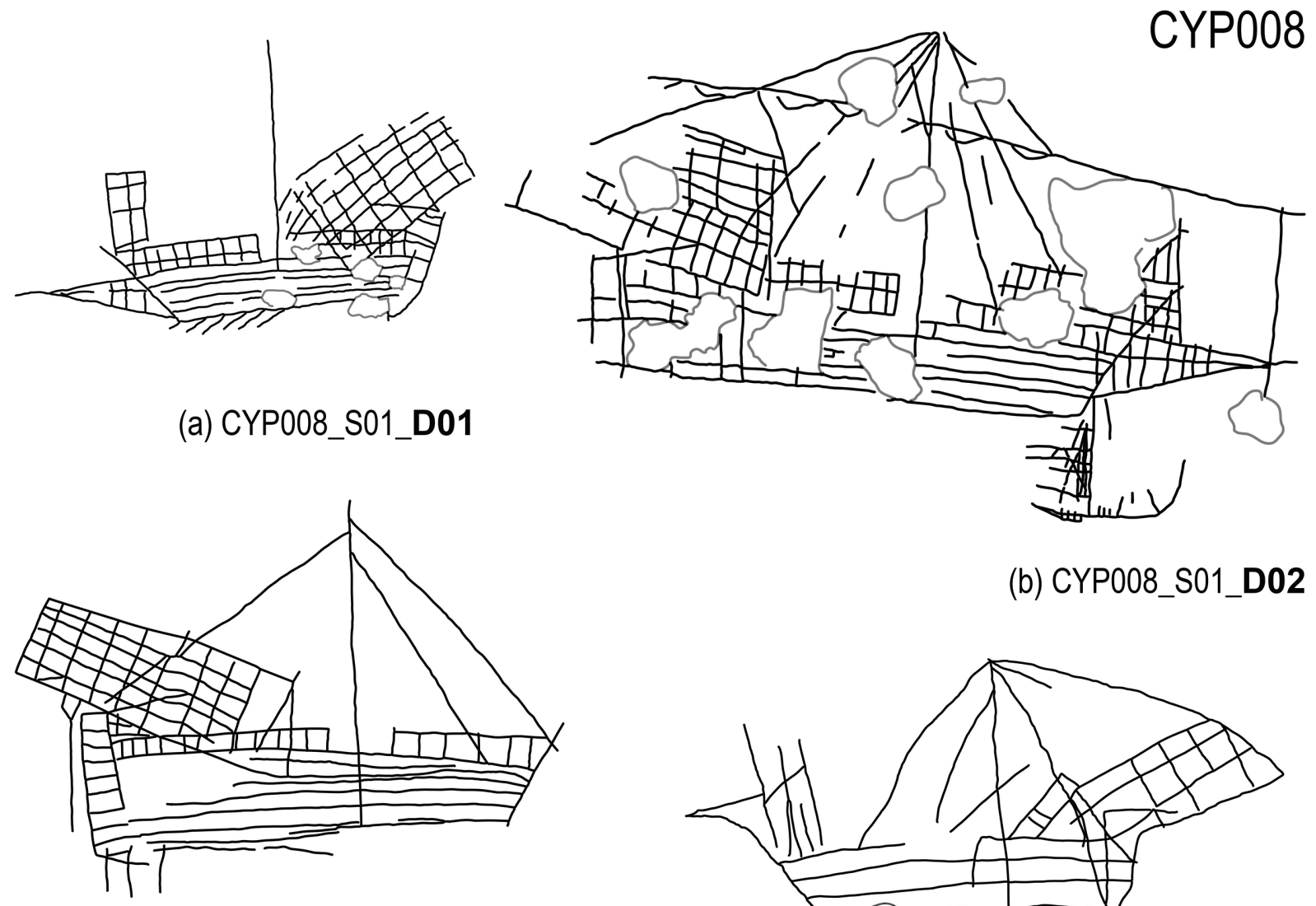

(b) CYP008_S01_D02

(c) CYP008_S01_D03

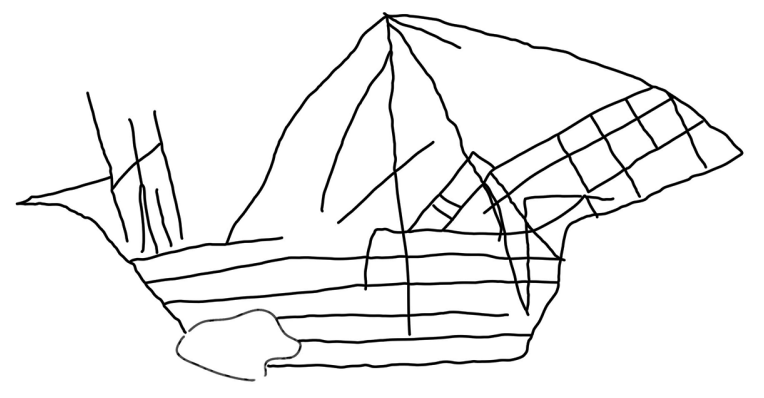

(d) CYP008_S01_D04

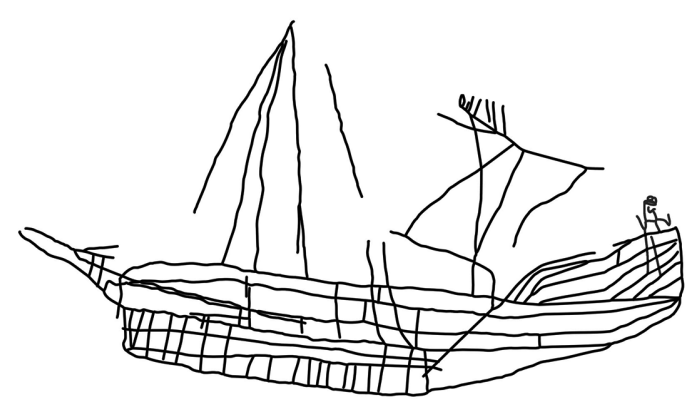

(e) CYP008_S01_D05

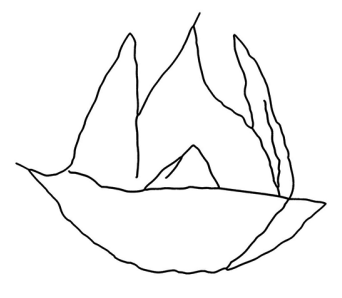

(f) CYP008_S01_D06

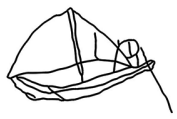

(g) CYP008_S01_D07

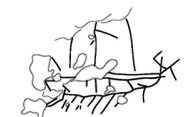

(h) CYP008_S01_D13

0

$40 \mathrm{~cm}$

Figure 10. The SG on the exterior northern wall of the Church of Saint Marina, Frenaros, Famagusta D (Digital drawing: Lefkothea Papakosta, University of Cyprus).

merchant ships, such as that of the Flemish master W.A. Kraeck from c.1470, see Landström, 1961: fig. 248; Ray, 2001: fig. 122).

D05 (Fig. 10e) illustrates a two-masted long ship. The mainmast is set forward of midships, and the mizzen just forward of the quarterdeck. Both are set vertically, without any depictions of yards or crow's nests. Rigging details are incomplete and the existence of a lateen sail uncertain. The hull has a straight keel and it gradually rises towards the stern. The stem is almost straight. The quarterdeck is drawn with oblique lines representing the external planking. Five parallel lines on the hull probably illustrate the planking. The 19 vertical lines on the lower part of the hull may depict some kind 


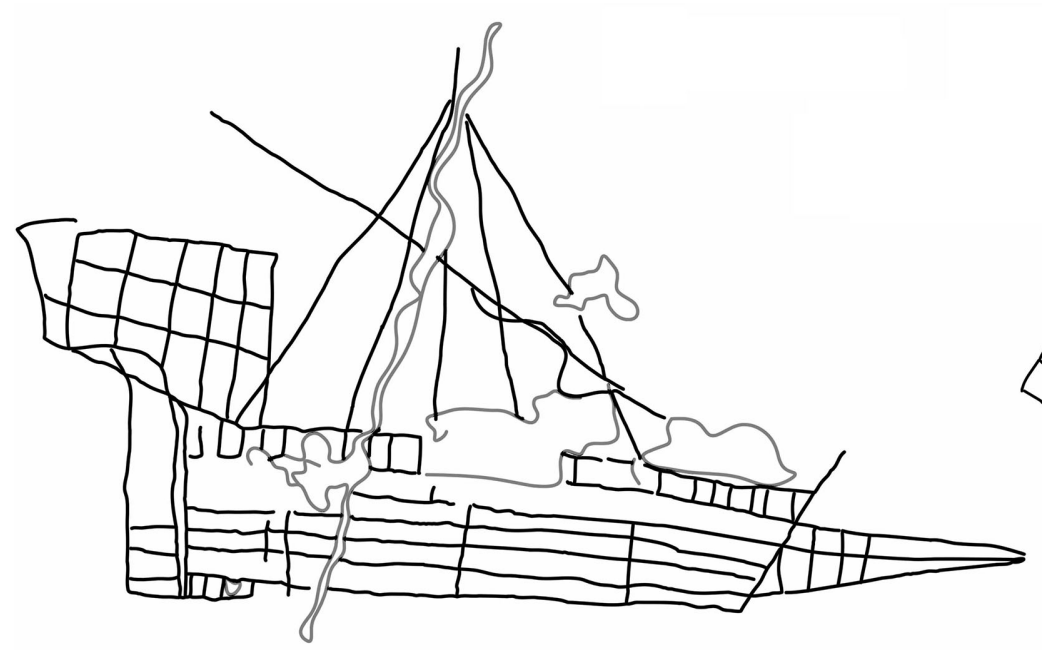

(a) CYP008_S03_D09

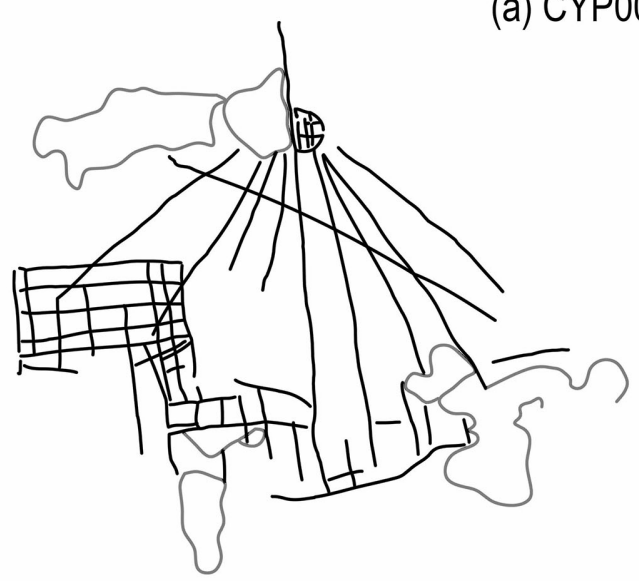

(c) CYP008_S02_D10
CYP008

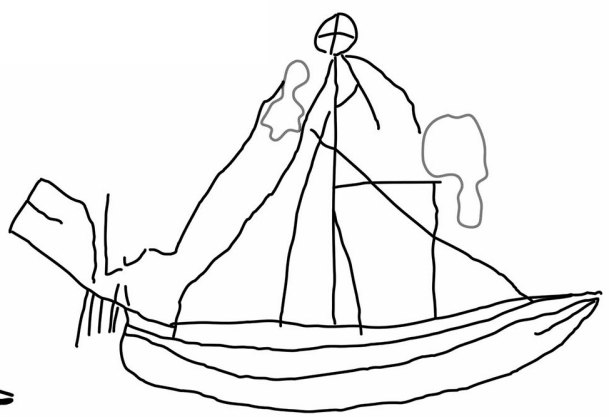

(b) CYP008_S03_D11

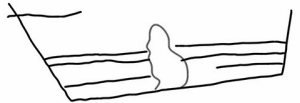

(d) CYP008_S04_D08

Figure 11. Church of Saint Marina, Frenaros, Famagusta: $a)-c$ ) SG on the interior northern wall: $d$ ) SG on the exterior western wall (Digital drawing: Lefkothea Papakosta, University of Cyprus).

of reinforcement, and, in any case, they are unlikely to represent oars because they do not continue beyond the outline of the hull. No rudder is depicted, but at the edge of the quarterdeck a human figure, possibly the steersman, can be observed. A prominent beak projects from the bow. The role of an oblique line that starts at the level of the third plank from the top and continues through the projecting beak remains unclear. A similar but more elaborate SG, dated to the 15 th century, has been found in the Palaco Ducale, Venice (Ray, 2001: fig. 125).

D11 (Fig. 11b) is a one-masted round vessel, with a curved keel, and a slightly rising bow. Planking or wales are represented by two parallel lines running from the end of the stern and curving upward at the bow. The mast, possibly with a crow's nest at the top, is placed vertically amidships, with no sail depicted. The rigging is incomplete and the existence of a yard uncertain.

The ships carved on the walls of Saint Marina belong to different types of merchant ships (galleon, cog, carrack, and galley), and some may have functioned as war vessels. They do not have parallels elsewhere on the island. They share common typological features that date them to the 15 th or the 16th century. Their common style of engraving could be indicative of a scene, portraying a particular event, although these are rare on Greek and Cypriot monuments.

More graffiti have been recorded on both surfaces of the north wall. On the exterior, mainly in the lower eastern part of the wall, diverse drawings are preserved representing circles with the radius marked, a human figure, a triangle, some oval shapes with veins that resemble stylized leaves, some stairs, and stars. These elements are quite common at sites on the island (Trentin, 2010: 309) and abroad, in Spain (Ozcàriz Gil, 2007: 159, 161) and northern Italy (Trentin, 2011: 198). Inside the church, on the fresco of the northern wall, a Latin inscription of a name is carved: Nicolaus Dersy Magav(?). The palaeographical elements are insufficient to define an 
accurate chronology, but it could date to the 16 th -17 th centuries.

\section{CYP021}

Church of Saint George Teratsiotis, Avgorou, Famagusta District.

A single-space building topped with a dome, combining Byzantine, Gothic and Early Renaissance architectural elements, this church dates from the end of the 15th or the beginning of the 16th century (Pavlidis, 1991, vol. 4: 332-333). Thirty-eight graffiti, of which $23 \mathrm{SG}$, were recorded: seven in the sanctuary - one in the northern niche, four on the apse and two in the southern nichethree on the northern wall, ten on the western wall, and three on the southern wall (Fig. 12a). Eleven of them are elaborate: three in the sanctuary, one on the south wall, one on the north wall, and seven on the western wall.

A three-masted ship is engraved on the north niche of the Sanctuary on a painted surface (CYP021_S09_D01). It is probably a merchant galley, with all masts in a vertical position (Fig. 12b.ii). The taller mainmast is placed amidships, penetrates the hull and crosses the keel. Oblique lines from the top of each mast do not provide a clear depiction of the rigging. The keel is almost straight and the bow is slightly curved. There is a superstructure only on the stern. Within the hull's outline, three horizontal lines indicate planking. The vertical lines may depict hull reinforcements, rather than oars.

On the apse of the sanctuary, on a painted surface, two almost identical graffiti depict long vessels, possibly galleys, but with neither oars nor rigging (CYP021_S01_D02, D03, Fig. 12b.i). They are both characterized by a light stern superstructure, a possible depiction of a stern rudder, and a prominent beak or ram.

Some of the SG on the rest of the walls were rather difficult to classify: although not particularly elaborate, it is clear that their carvers intended to draw details, such as the rigging in CYP021_S08_D24 on the north wall (Fig. 12b.iii); a similar pattern at the bottom of the masts, most probably depicting shrouds, can be also found elsewhere in Cyprus, as for example in CYP032_S01_D08 (Fig. 17g) (for a similar pattern see also the SG from the Tower of Winds in Athens, in Damianidis, 2014: 458-459).

CYP021_S04_D15, D26-D28, D30-D31 are the most elaborate SG in the monument, all carved on the southern half of the western wall (Fig. 13). Most of them bear features of ships from the western Mediterranean. The most detailed one, D15, is a twomasted lateen-rigged galley (Fig. 13a). Both masts are shown in a vertical position. The mainmast is taller and placed aft of midships. The foremast is set with a large lateen sail. The keel is almost straight. The sternpost is missing, as is the rudder. The depiction of the bow is slightly curved. A series of criss-cross lines within the hull's outline may represent sheathing. Eighteen oblique lines under the hull depict the oars. They are carved in groups of three, possibly indicating the rowing system known as alla sensile, which was gradually replaced by a la scaloccio during the 16th century (Burlet, 2005). If this was indeed a galley with 18 oars, then it was probably a small one, because 'great galleys' had 25 three-man benches on each side (Gardiner, 1995: 123). Two previously unpublished similar SG with the same rowing system have been recorded in Greece: one in the monastery of Hosios Loukas, Phocis, Greece, and one in the temple of Hephaestus, Athens, which was used as the church of Saint George (Fig. 14).

D31 is only partly preserved, but it could also represent a long ship, possibly a merchant galley (Fig. 13f). Only one mast, set vertically on the hull, is shown clearly. The mast has a yard and a flag at the top. A second oblique line above the mast could be part of a second mast and rigging, as an oblique line runs from the top of the triangle and ends at the stern. The bow is missing. Three straight and parallel lines depict the form of the hull and the sternpost is also straight. A curved line at the sternpost may depict the rudder, and the vertical line above the gunwale, at the stern, is possibly the tiller. A possible flag and a damaged depiction of a light superstructure are preserved at the stern. Within the hull's outline and between the keel line and the one above it, a series of criss-cross lines might depict sheathing. The representation of the oars starts from the keel line: they are in pairs, perhaps indicating that two oarsmen rowed alongside each other on the same bench, each pulling their own oar. If so, maybe this is another example of the alla sensile rowing system.

D30 depicts a one-masted vessel. The hull, with a relatively straight keel, rises gradually at both ends (Fig. 13e). Only one mast, vertically set on the hull, is shown with a yard secured halfway up the mast. Three oblique lines from the top of the mast to the right, and one to the left, represent part of the rigging. Within the hull's outline and between the keel line and the one above it, five oblique lines do not go beyond the hull outline. By contrast, two oblique lines near the stern, crossing through the hull's outline, possibly represent oars.

The remaining three SG of this wall (D26, D27, D28) depict one-masted vessels, with multiple lines indicating the rigging. D26 and D30 appear to be long vessels (Fig. 13b-d). D28 is a round, merchant ship possibly with a lateen sail and with some characteristics of a 16th-century caravel or grippi (Landström, 1961: 103, fig. 267; Ray, 2001: 178).

CYP021_S05_D33, carved on the northern half of the western wall, depicts a vessel with slightly round ends that could also be associated with the previous group (Fig. 13g). The hull is covered with oblique and vertical lines, which is an uncommon pattern in Cyprus. The meaning of these lines is not clear; they may be interpreted as either artistic shading, or the sheathing, 
(a)
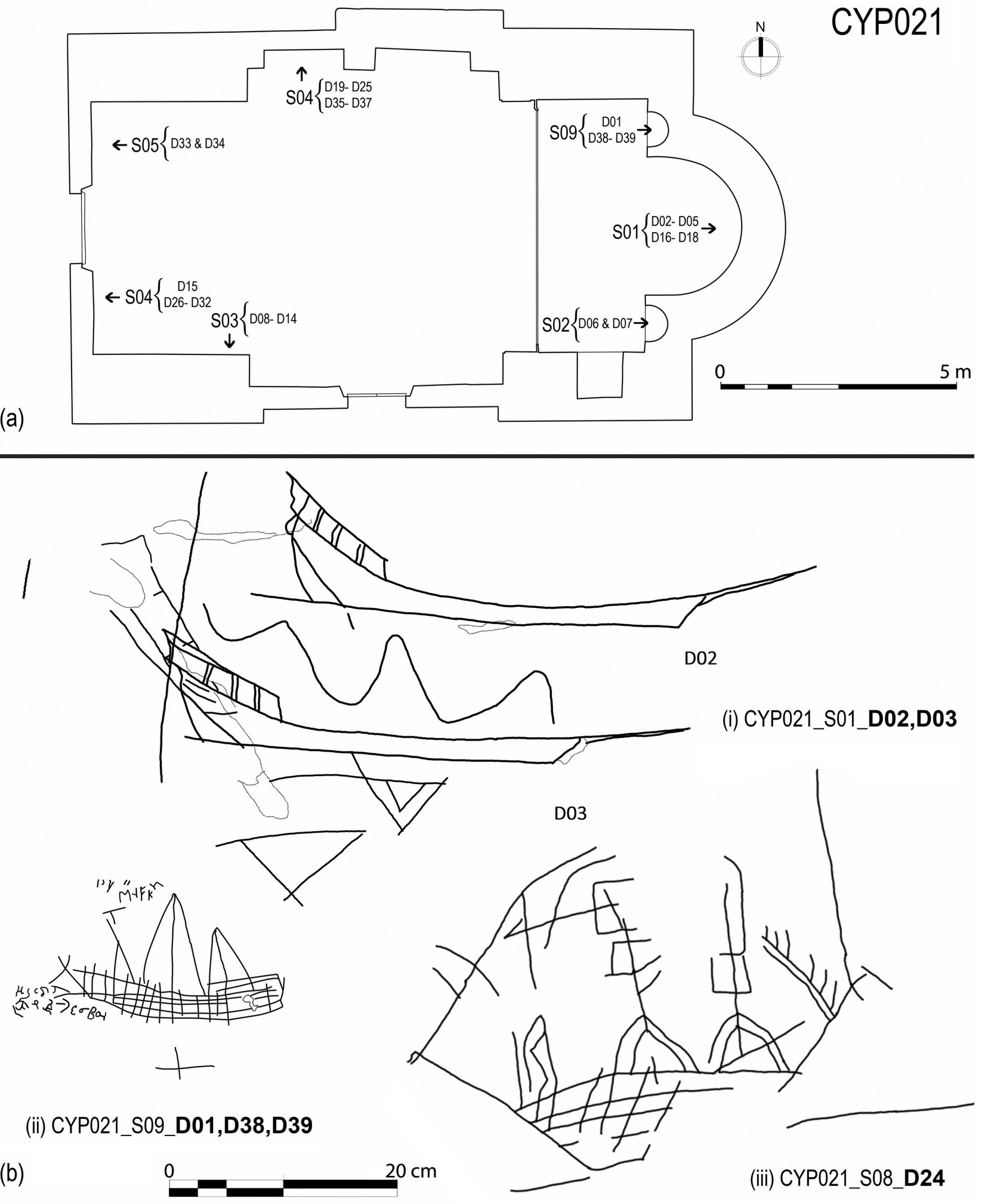

Figure 12. Church of Saint George Teratsiotis, Avgorou, Famagusta District (CYP021): a) location of SG (Plan: Lefkothea Papakosta, University of Cyprus; Dante Abate, The Cyprus Institute); b) elaborate SG; (i) sanctuary: (ii) northern wall: (iii) southern wall (Digital drawing: Lefkothea Papakosta, University of Cyprus). 

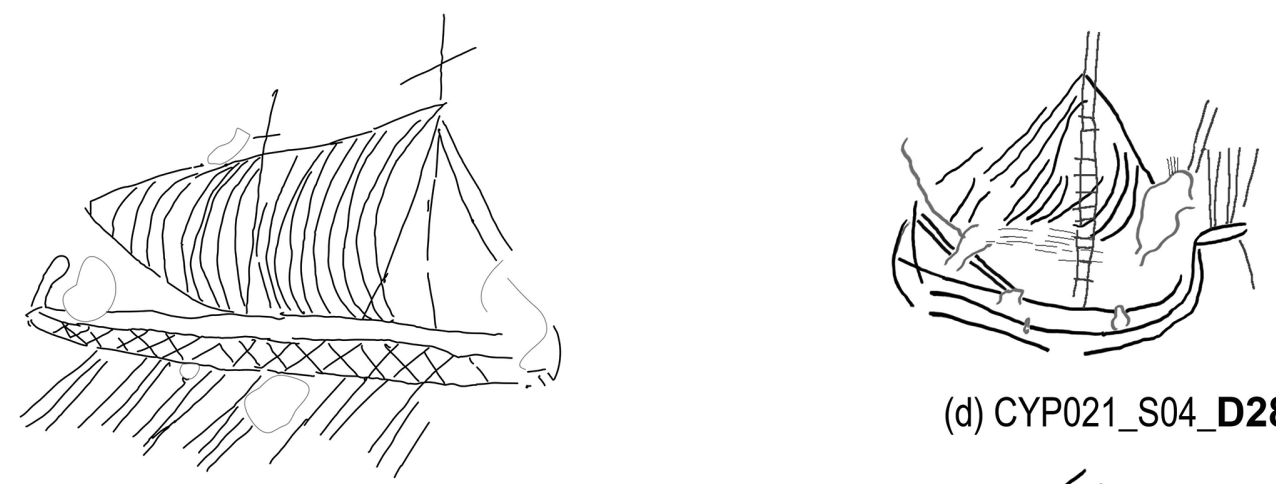

CYP021

(a) CYP021_S04_D15

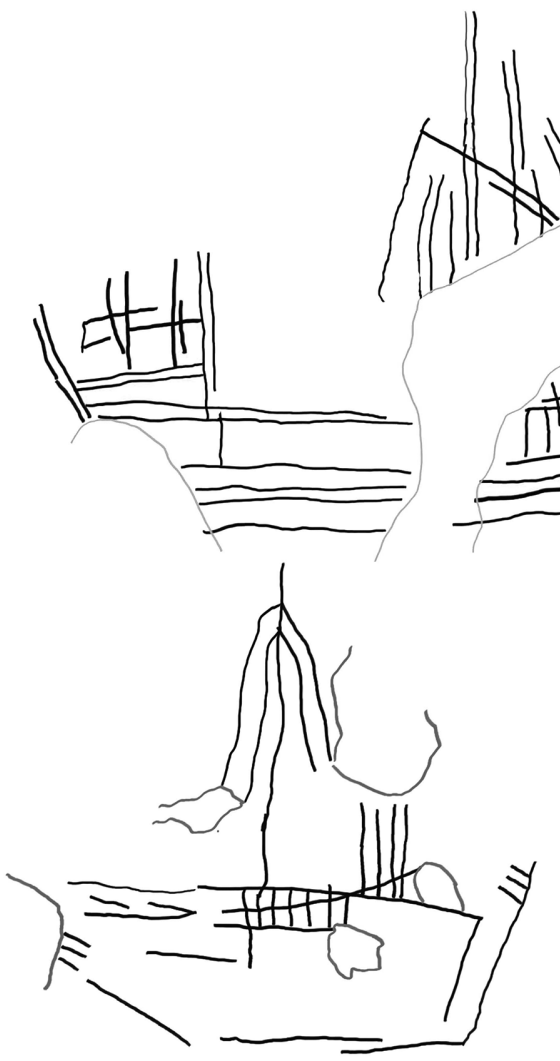

(d) CYP021_S04_D28

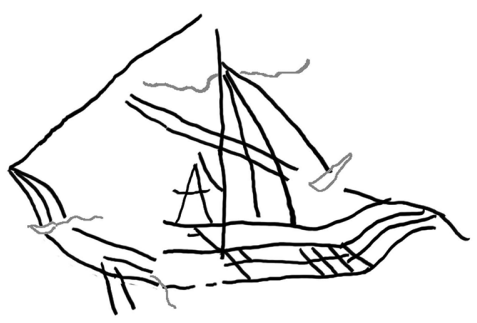

(e) CYP021_S04_D30
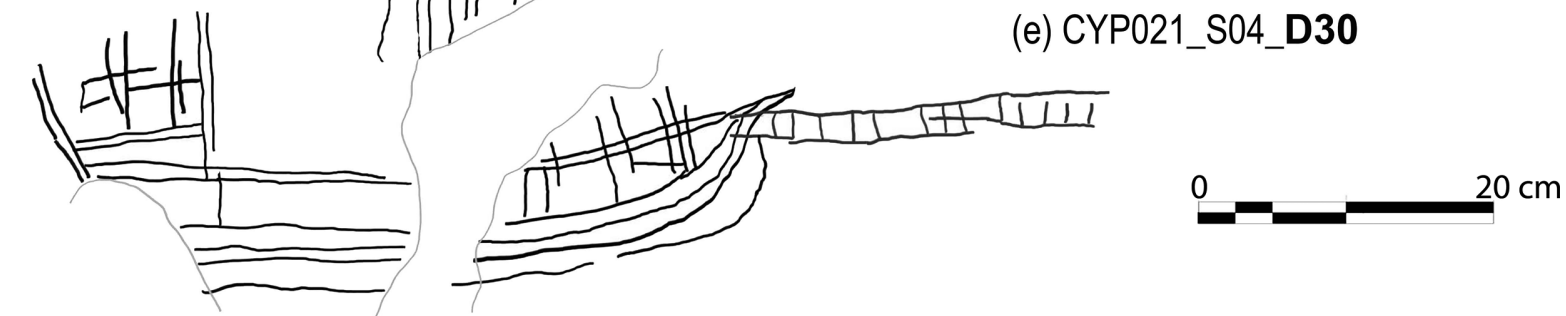

(b) CYP021_S04_D26

(c) CYP021_S04_D27

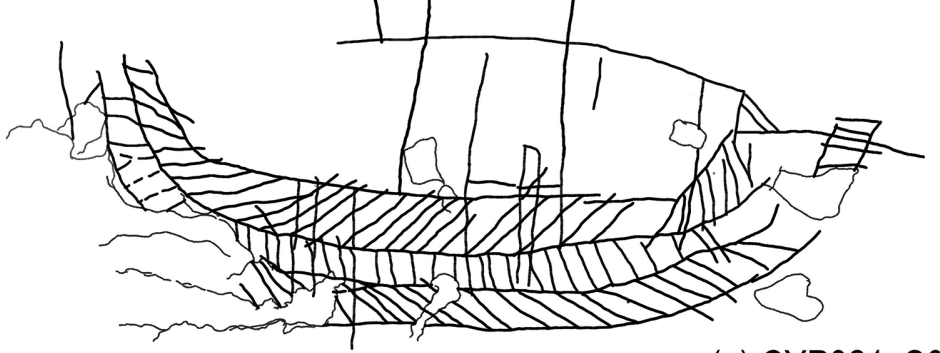

(g) CYP021_S05_D33

Figure 13. The SG on the western wall of the Church of Saint George Teratsiotis (CYP021): $a$ ) $f$ ) south of the entrance; $g$ ) north of the entrance (Digital drawing: Lefkothea Papakosta, University of Cyprus). 


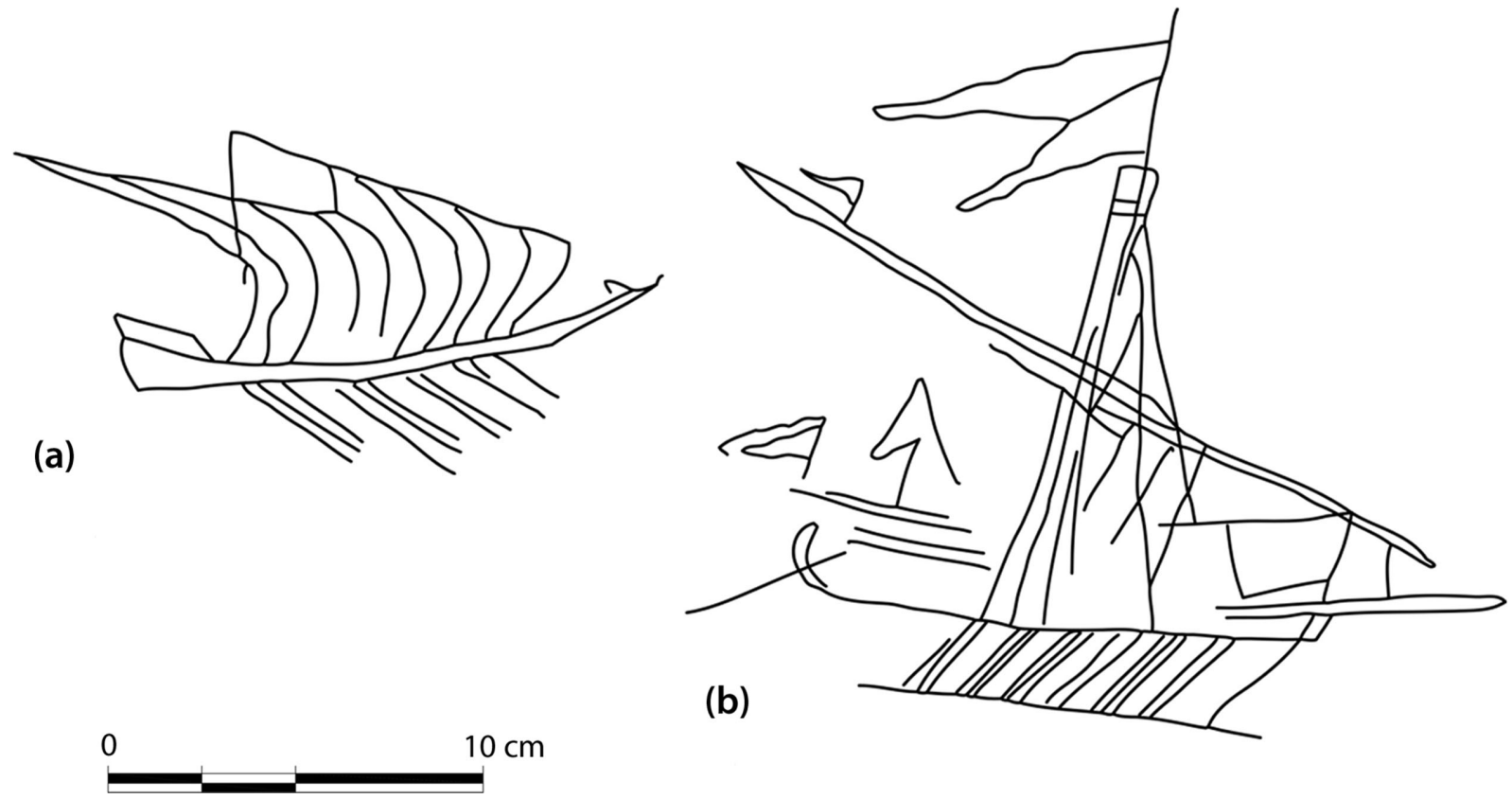

Figure 14. Graffiti of two-masted, lateen-rigged galleys, from Greece (survey by K. Delouca): $a$ ) Katholikon, Hosios Loucas monastery, Phocis, Greece; $b$ ) the second column from the north-east colonnade, Temple of Hephaistos (Church of Saint George), the Athenian Agora, Athens, Greece.

or a way to highlight the different elements of the construction. There is no depiction of rigging and the two possible masts are shown with two lines vertical to the hull. A small rectangle at the top of the tallest one may represent a crow's nest or a flag.

The SG on the western wall of Saint George Teratsiotis, present morphological features of the 16th or 17 th centuries, although only the oared ships could be dated with more certainty to the 16th century. The same date can be suggested for several inscriptions recorded in the church, based mainly on the type of letters. Greek inscriptions on the apse, around figures of the saints, consist of names and their religious status (for example $\iota \varepsilon \rho o \mu o ́ v \alpha \chi o \varsigma$ - monk). The only Latin inscription at the monument was found on the north wall, close to Saint Panteleimon, and is possibly an attempt to reproduce the saint's name (Pantele.ia).

\section{CYP023}

Church of Saint George of Angona, Ormidheia, Larnaca District.

This is a single-aisled barrel-vaulted church, with the narthex topped with a low dome without a drum (Fig. 3a). The narthex is dated in the 12th century; the date for the main building is estimated as the 15th or the 16th century (Antoniadis, 2011: 216-220).

An impressive group of $23 \mathrm{SG}$ cover the entire apse and the walls of the parabemata, on either side of the apse (Fig. 3c). Six of them depict elaborate sailing vessels (Fig. 15).
CYP023_S01_D01 is carved on the wall north of the apse (Fig. 15a). The hull is not clearly depicted, but it seems probable that it is a two-masted ship with square sails. The mainmast is depicted vertical to the hull, with ratlines probably leading to a crow's nest. The depiction of the rigging is incomplete. Some 23 vertical lines under the hull may indicate oars, although square sails and oars are a very uncommon combination. On the left side of the ship and outside the ship's outline, three long lines ending in a triangular pattern are difficult to interpret; it is possible that they are related to some kind of fishing gear, although we have found no parallels of fishing boats with two masts. Two similar lines are depicted on the bow of CYP023-S03-D23 (Fig. 15c). The shape of the hull and the sails of this graffito have strong similarities with CYP023-S03-D28 (Fig. 15f). Both ships are two-masted but with open sails facing the wrong side, that is towards the stern of the ship.

Only a small part of the hull of CYP023_S02_D08 is preserved, most probably the stern, if we take into consideration the position and height of the masts (Fig. 15b). At least three masts are depicted with no rigging details. For the main and the mizzen-mast, the inclination of the yards suggests lateen sails.

CYP023_S03_D014 is a three-masted, long-keeled vessel with an elaborated stern (Fig. 15d). The mizzenmast carries a lateen sail, whereas the central mast, placed amidships, carries a long yard and a flag with no depiction of sails, although the inclination of the yard suggests a lateen type. The lines depicting the foremast and its sail, probably also lateen, are only partly preserved. 


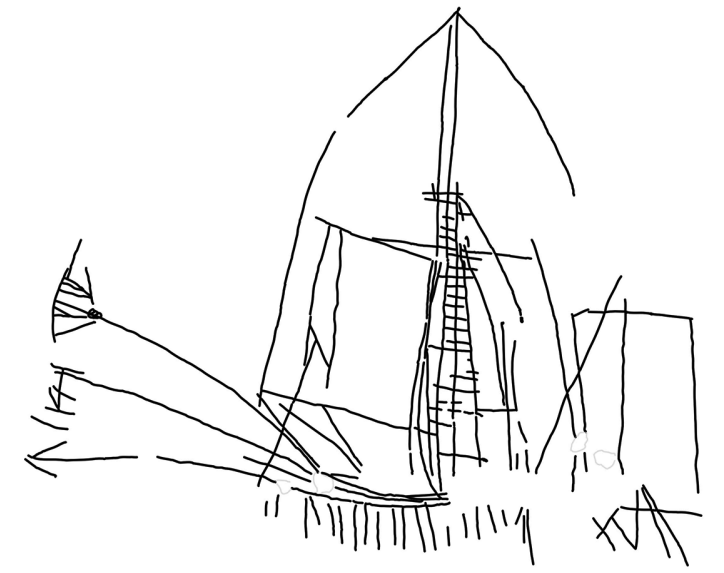

(a) CYP023_S01_D01

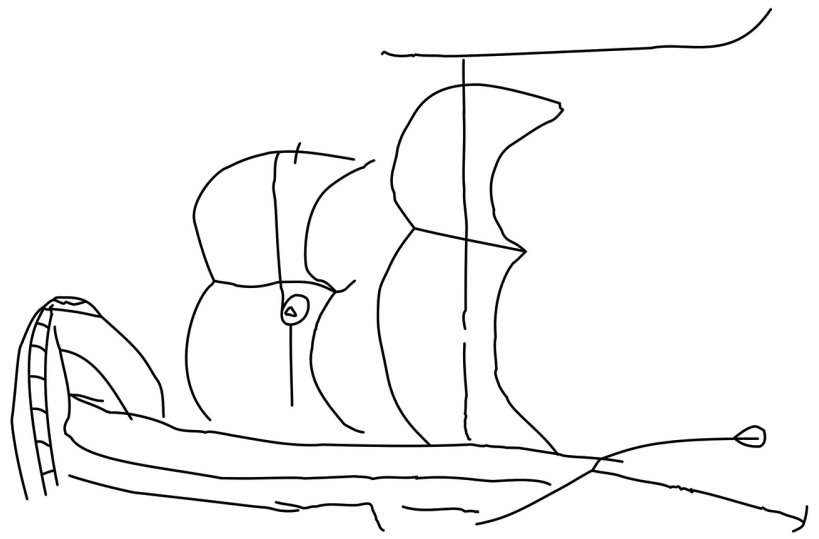

(c) CYP023_S03_D23

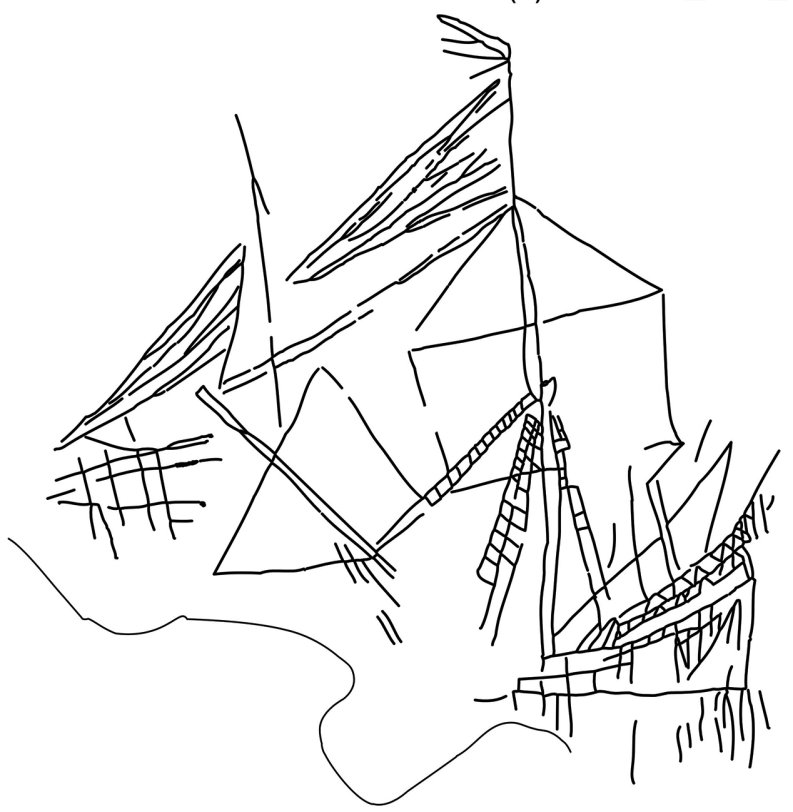

(e) CYP023_S03_D15
CYP023

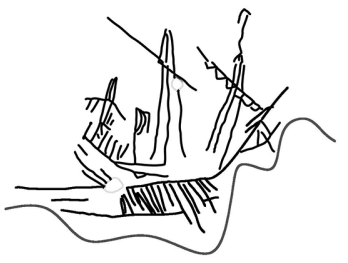

(b) CYP023_S02_D08

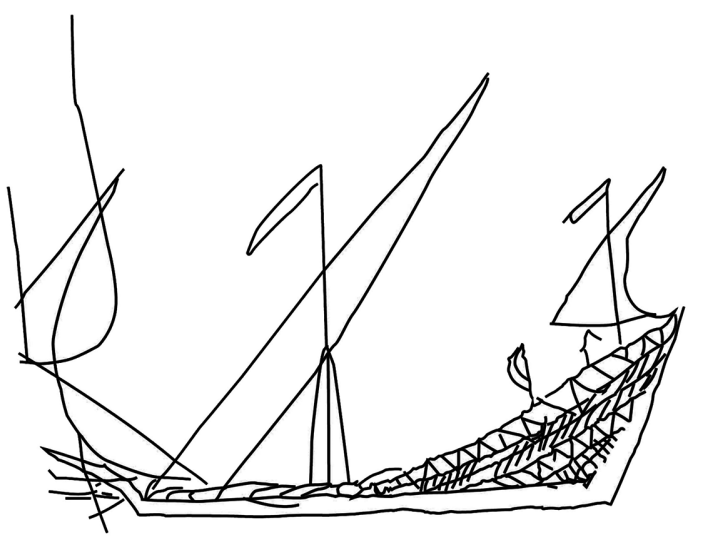

(d) CYP023_S03_D14

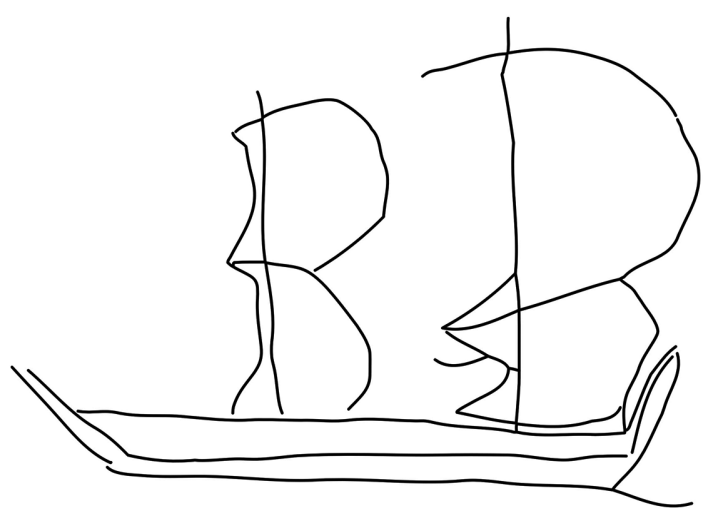

(f) CYP023_S03_D28

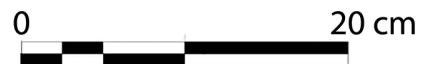

Figure 15. The elaborate SG from the Church of Saint George of Angona, Ormidheia, Larnaca District (CYP023) (Digital drawings: Lefkothea Papakosta, University of Cyprus). 
CYP023_S03_D15 is a partly destroyed SG (Fig. 15e). Two masts with topsails, flags, and ratlines are preserved. The depiction of the stern castle, which is not integrated with the lines of the ship, could suggest a galleon.

\section{CYP032}

Church of Saints Athanassios and Cyril, Mennogeia, Larnaca District.

This small cross-in-square, domed church, was built at the end of 15 th or beginning of 16th centuries, on an earlier three-aisled basilica (Fig. 16a) (Jeffery, 1983: 187; Procopiou, forthcoming). A total of nine SG have been documented on three different surfaces: seven on the western face of the north-western wall that supports the dome, one on the south door pilaster and one on the south wall. The last two are associated with very fragmentary inscriptions in Greek.

Five of the nine SG depicted in this monument were classified as elaborate and were all found on the same wall (Fig. 16b) - the western face of the northwestern arch that supports the dome. Most of them were superimposed on each other.

CYP032_S01_D01 and D02 seem to depict the same type of three-masted merchant vessel with rigging details (Fig. 17a-b); the shape of the hull is also similar to CYP032_S01_D03 (Fig. 17c). In D01, D02 and CYP032_S01_D04 (Fig. 17d), the stern rudder is depicted as a rectangle with one vertical line almost parallel to the sternpost and many parallel ones. Only on D04 is there an anchor hanging amidships. On the outlines of the hulls of D01-D05, a series of vertical lines with one horizontal line in the middle, possibly indicate the frames or another kind of vertical reinforcement; it is unlikely that they depict oars as they don't extend outside the outlines of the hulls.

CYP032-S01-D08 (Fig. 17g) is also a merchant vessel with a straight keel, an oblique sternpost, and a slightly curved bow. It has three vertical masts with a possible depiction of rigging only for the central one. Eight oblique lines under the keel could represent oars. The zig-zag pattern in the hull's outline is difficult to interpret; it could depict a type of sheathing.

\section{CYP034}

Church of Panagia Asprovouniotissa, Frenaros, Famagusta District.

This single-aisled barrel-vaulted church with a narthex, was probably built during the 15 th century but the wall paintings date to the 16th century (der Parthog, 2006: 325). Two SG, both elaborate, were found on the north interior wall (Fig. 18).

CYP034_S01_D01 and D02 (Fig. 18b), may depict the same type of ship, a round commercial vessel with round and high ends. Within the outline of the hull, two strakes or wales are shown. The vertical lines may refer to reinforcements. D01 is more elaborate, with three masts. The mainmast is depicted with a vertical line down to the keel, with ratlines leading to a centrally placed large crow's nest, indicating it would have supported a square sail. The topsail is probably square, as are the topsails on the mizzenmast and the foremast. A vertical central mast with ratlines and part of the rigging is also depicted on D02. Similar SG, identified as 15th-century round ships, were found in La Torre dels Enagistes in Manacor, Mallorca (González Gozalo and Font, 2007: 192, no. 126). Round ships can also be found on at least two maps printed in Nuremberg in 1570, depicting the Turkish invasion of Cyprus: Y Cypern by Matthes Zündt and Diese innsel Cipern ist wie das Seinst Konnigreich Sie liegt von Venedig, by Bathasar Ienichen (Stylianou, 1980: 56-57, figs. 57b and, 65). In this context, it is tempting to associate the human figure depicted on the mast of D01 with the memory of the brutal torture and execution of Marcantonio Bragadin, the Captain General of Famagusta, whose flayed skin was hoisted to the yardarm of the Turkish flagship after the Ottomans besieged the city (Hill, 1948: 1033).

\section{Analysis}

By the end of the project, a total of 163 monuments had been visited, and SG were located in almost $25 \%$ of them (44 monuments)(Fig. 1): two fortification complexes (CYP007 and CYP042), one house (CYP013), three mosques (CYP035, CYP039 and CYP041) and 39 churches (see Appendix). This is not an unusual distribution, given that churches and forts constitute the majority of the preserved monuments dating from the Medieval period; of the 163 surveyed sites, 158 were religious monuments. The location of the graffiti-monuments with respect to settlements (cities or villages) may also reflect realities of the medieval and pre-modern archaeological record; for example, the fact that only five monuments have been recorded in cities and 14 in villages (Table 1) might be the result of the regular re-plastering of wall surfaces in urban centres. Whatever the reason, however, the most coherent group of preserved SG was recorded on churches or monasteries outside settlements: almost half (20) are located in the countryside and five on the outskirts of villages. This might not necessarily represent a behavioural preference for rural churches by the graffiti carvers, but it certainly shows that such churches were definitely visited by them.

Focusing on the distribution of SG on the walls of churches in particular, where 203 out of the 233 SG were documented, a preference for the north wall and the apse is observed (Table 3); the spatial sanctity of the sanctuary containing the apse could be regarded as a reason for the proliferation of SG in this space but the preference for the north wall cannot be easily explained. The majority of SG have been found in the interior of buildings, a fact that might be attributed 

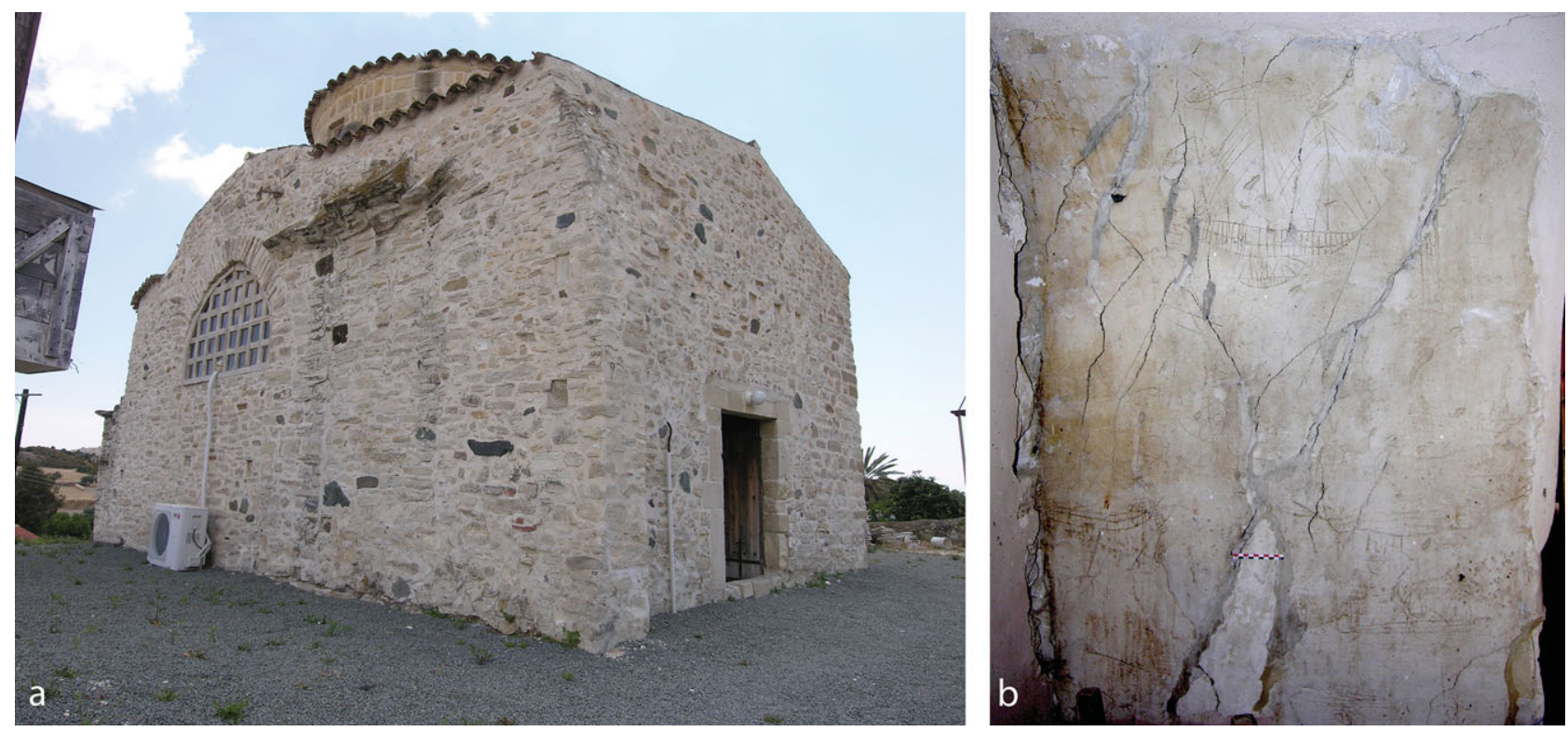

Figure 16. a) The Church of Saints Athanassios and Cyril, Larnaca District (CYP032); b) the western face of the north-western wall that supports the dome, where the elaborate SG were found.

to the vulnerability of the exterior walls to weather conditions. Bollon and Imhaus (2009: 424) argued that $\mathrm{SG}$ on the exterior walls are less religious than the ones on the interior and aimed to attract the attention of passers-by. Still, it is doubtful whether the 40 simple or the 25 uncertain SG documented on the exterior of church walls during the KARAVOI project were likely to attract visual attention, due to their small size and lack of artistic execution. Only 15 elaborate SG were identified on external facade walls. But five of them come from the same church, Saint Marina, Frenaros (CYP008), and their carver (or carvers) most probably drew three similar, also elaborate SG on the interior of the church (see the analysis of the SG in CYP008, above). As this instructive example suggests, we have no evidence that the selection of surfaces for the execution of elaborate SG was made based on the fact that they were interior or exterior. It is possible that carvers might have selected the specific surfaces because they were not covered with wall paintings, offered plenty of space for drawing, and were still suitable for the commemoration of an event in a sacred place. In other words, the carvers' preferences and/or behaviour is better understood through a monumentspecific analysis, which takes into consideration other parameters, such as the architecture of the building and the decoration of the walls.

The lack of comparative studies or large-scale surveys for medieval graffiti from other regions in the Mediterranean does not allow for a more elaborate discussion of possible patterns regarding the location of the graffiti-monuments on Cyprus. The context of the monuments, however, remains very important for the interpretation of SG, especially regarding the people that carved them and the social groups they represent. Regardless of the impact that restoration issues may have on the survey results, it is clear that graffiti-monuments cluster in Larnaca and Famagusta D (Fig. 1), with 12 monuments in each. In the remaining Districts the numbers were lower: five in Limassol $\mathrm{D}$, six in Nicosia D, and nine in Paphos D. In both Famagusta and Larnaca D, the monuments with the largest concentrations of graffiti have also been recorded (Table 2).

It is worth noting that none of the 44 graffitimonuments was on the coast. The closest ones to the sea were the three monuments in the city of Famagusta but most of the remaining graffiti-monuments do not even have a sea view; four of them were located as far as the Troodos mountains: the Dormition of the Mother of God, Kourdali, (CYP006), Archangel Michael, Monagri (CYP009) (Fig. 5b), Panagia Amirou monastery, Apsiou (CYP027) (Fig. 5e) and Church of the Holy Cross, Pelendri, (CYP031). In other words, the graffiti-monuments were not chosen by the carvers because of their vicinity to the sea or their association with maritime activities, as has been suggested for SG elsewhere, such as Ibiza (Hermanns, 2010) and Normandy (Carpentier et al., 2001).

\section{The simple $S G$}

The 87 documented examples of simple SG, that is graffiti of small ships without particularly identifiable features, were found in 32 of the 44 surveyed graffitimonuments, located in all six districts ${ }^{2}$ (Fig. 19). In most buildings ( 25 of 32 ), no more than three simple SG have been recorded, usually on the same wall. Most of them have been found in Famagusta and Larnaca D, but in Paphos D they comprise $55 \%$ of the total (19 of 34) (Table 2). They give the impression that the carver 

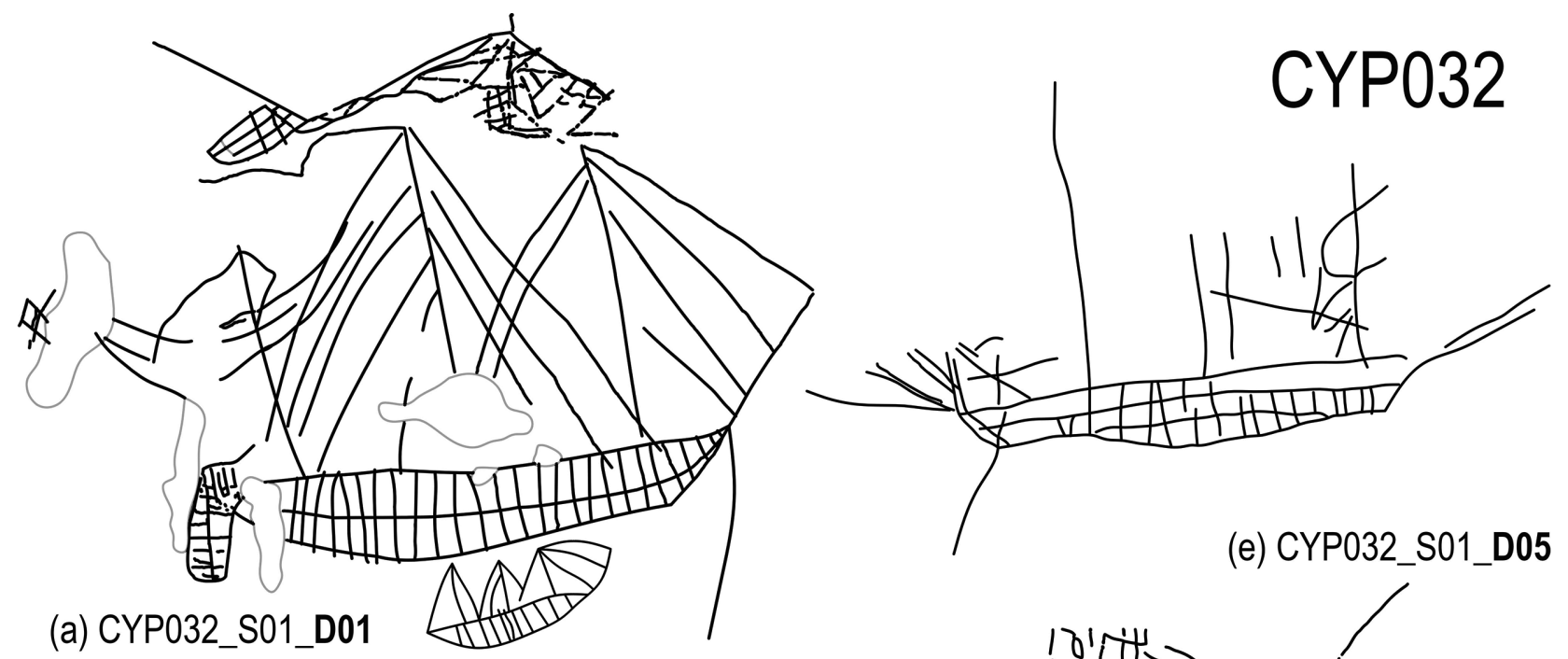

(b) CYP032_S01_D02

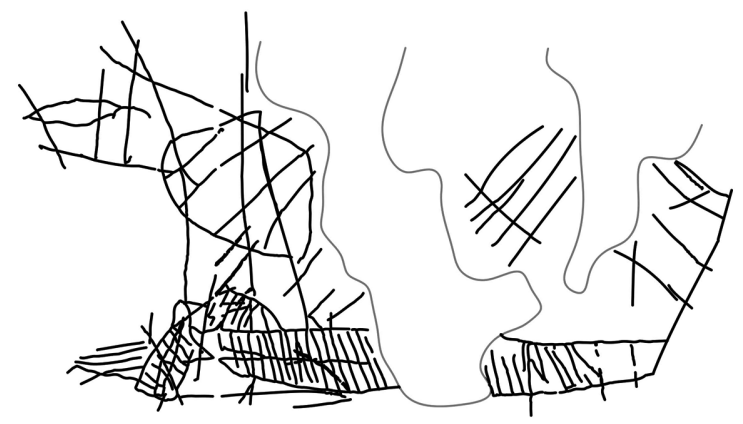

(c) CYP032_S01_D03

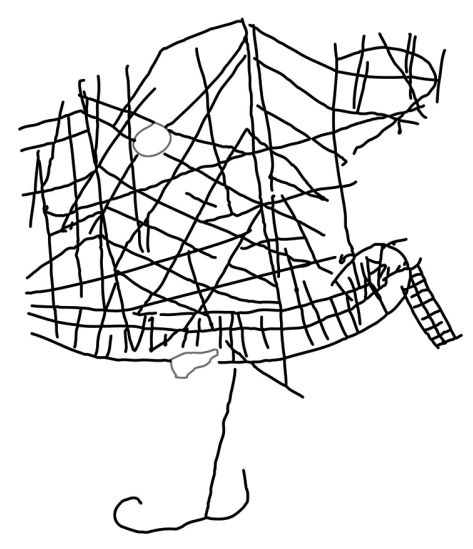

(d) CYP032_S01_D04

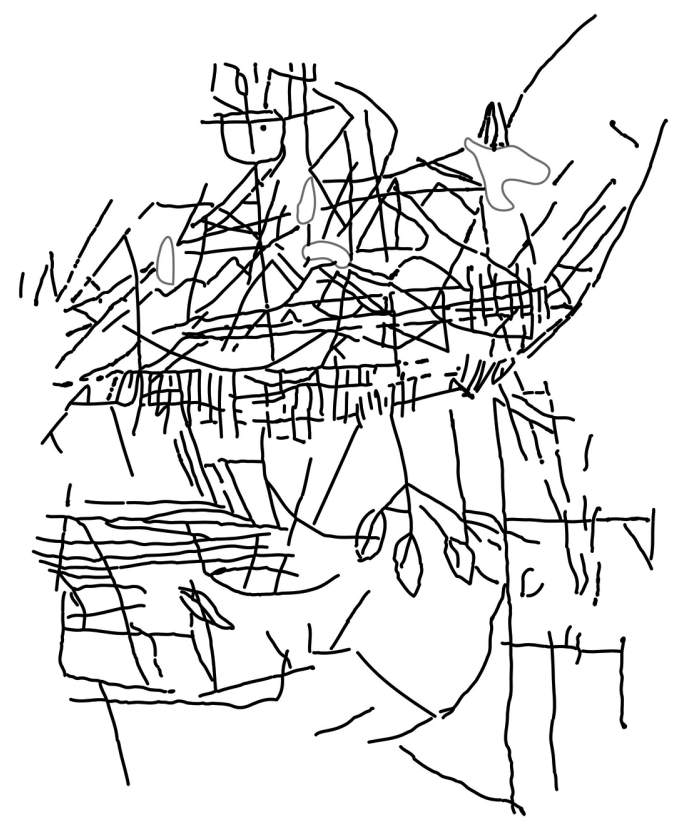

(f) CYP032_S01_D06

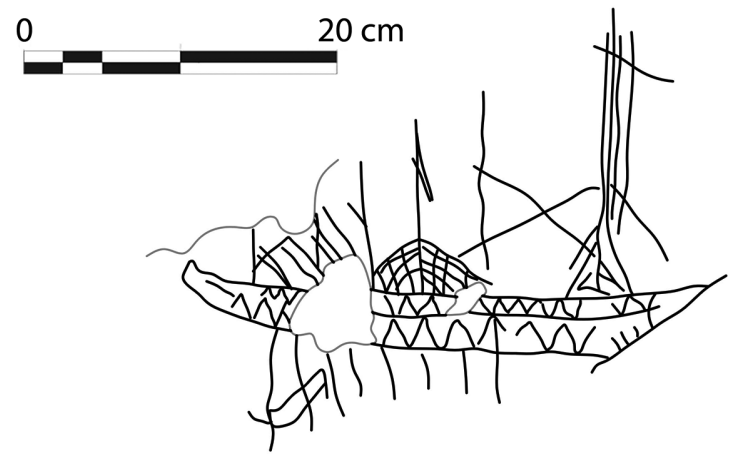

(g) CYP032_S01_D08

Figure 17. The elaborate SG of the Church of Saints Athanassios and Cyril, Larnaca District (CYP032) (Digital drawings: Lefkothea Papakosta, University of Cyprus). 

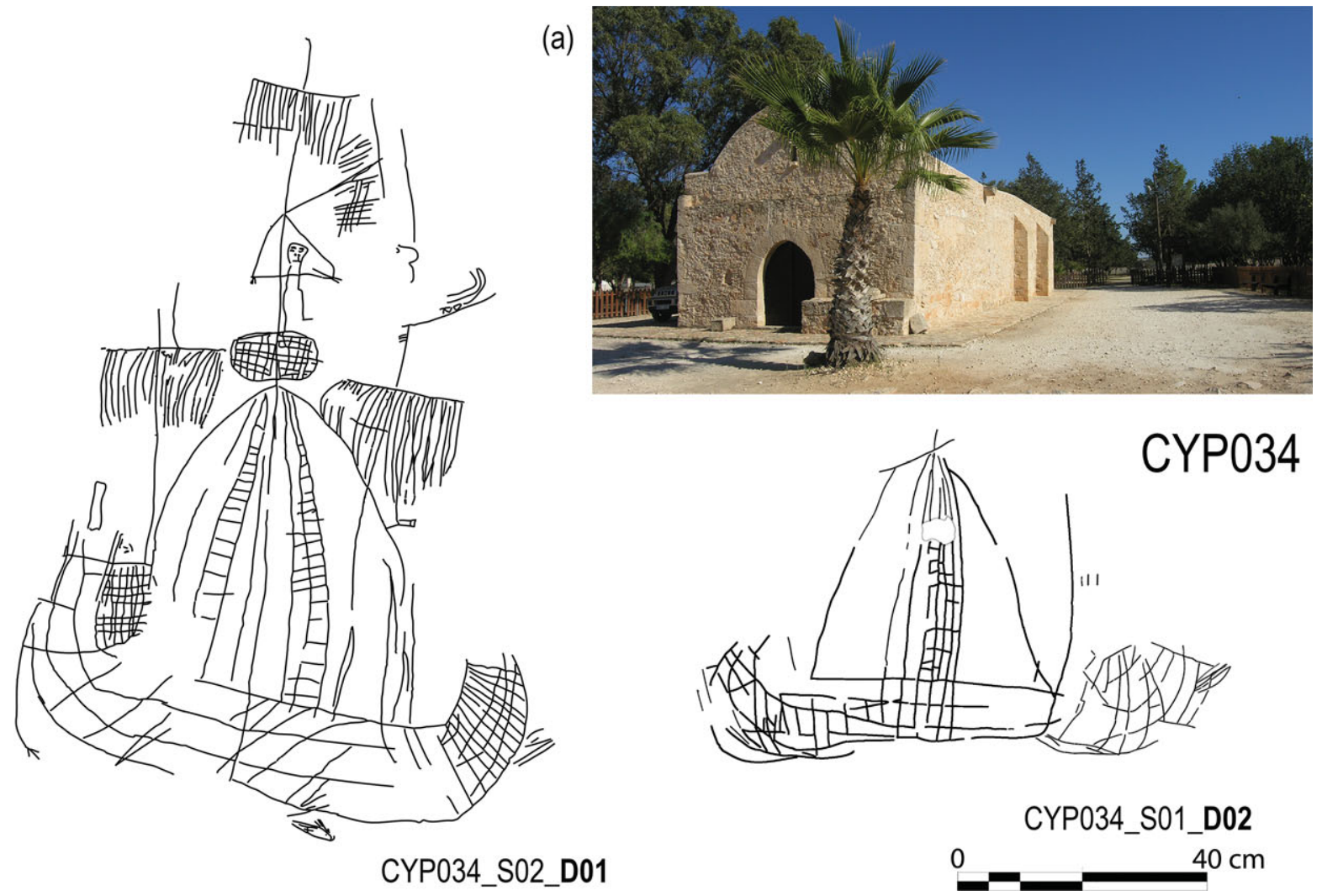

Figure 18. a) The Church of Panagia Asprovouniotissa, Frenaros, Famagusta District (CYP034); $b$ ) the SG (Digital drawings: Lefkothea Papakosta, University of Cyprus).

Table 3. The distribution of Ship Graffiti on the walls of the churches

\begin{tabular}{|c|c|c|c|c|c|c|c|c|c|c|}
\hline & \multicolumn{5}{|c|}{ Interior walls } & \multicolumn{5}{|c|}{ Exterior walls } \\
\hline & East & West & North & South & Subtotal & East & West & North & South & Subtotal \\
\hline Elaborate & 12 & 8 & 29 & 6 & 55 & 4 & 1 & 9 & 1 & 15 \\
\hline Simple & 17 & 1 & 10 & 9 & 37 & 13 & 7 & 12 & 8 & 40 \\
\hline Uncertain & 11 & 4 & 8 & 8 & 31 & 7 & 0 & 6 & 12 & 25 \\
\hline Subtotal/wall & 40 & 13 & 47 & 23 & 123 & 24 & 8 & 27 & 21 & 80 \\
\hline Total & & & & & & & & & & 203 \\
\hline
\end{tabular}

may have intended to show that what she/he drew was a ship, but not necessarily a specific one; such graffiti are common throughout the Mediterranean, but due to their lack of details, they seldom attract the attention of scholars unless they are found in large numbers (for Aegina Island Greece, see Meinardus 1970-1972: 37, fig. 1. 5-21 and for Mallorca, González Gozalo and Font, 2007: nos 14, 9, 30, 83, 111). Their rudimentary nature could be attributed to the carver's lack of drawing abilities or lack of personal experience of a ship. The fact that on Cyprus they were found mainly in religious monuments allows their interpretation as votive offerings, scratched hastily and in a schematic way. Or, they may be symbols, since the ship has a particular symbolism in Christianity (Murray and Murray, 1998: 488; see also the comments for the SG in the Parthenon, Orlandos and Vranousis, 1973: 27); simple ships, especially in monuments further inland, such as CYP004, CYP006, CYP030, and CYP031, were found carved on the painting of the Converging Fathers, in the sanctuary.

On Cyprus, unlike other Mediterranean islands, such as Mallorca (Darder i Mari and Gonzales Gozalo, 2006) or Skopelos in the Aegean (Mouzakis, 2000), the numbers of simple SG per monument are rather low, which might indicate that such votive offerings or symbolic signs were not a common practice on the the island. On the other hand, they have a wide distribution and represent a phenomenon that does not seem to have stopped until the 20th century; for example, two simple SG, were recorded on CYP038, a church of Paphos D dated to 1950 . 


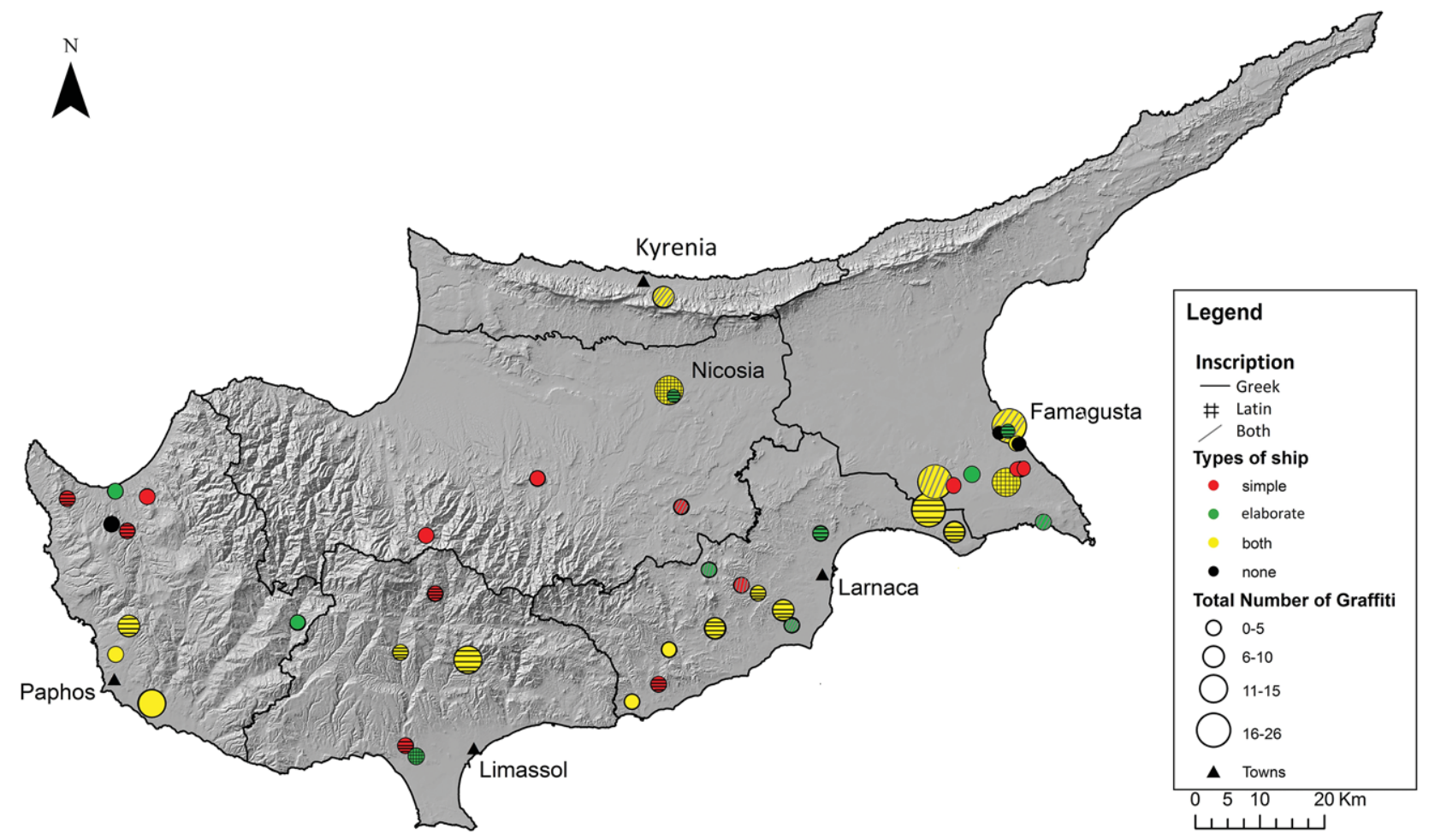

Figure 19. The distribution of graffiti monuments with inscriptions (Greek and Latin) and SG (simple and elaborate) (Map and GIS by Niki Kyriakou, University of Cyprus).

\section{The elaborate $S G$}

The distribution of elaborate SG is less diverse (Fig. 19). Almost 30\% of them (25 of 86), dated mainly to the 18th-19th centuries, cluster in the urban graffitimonuments (CYP013, CYP029, CYP035, CYP036, CYP042). The majority of the remaining (43 of 61 , or $50 \%$ of all the elaborate $\mathrm{SG}$ ) were found in monuments of Famagusta and Larnaca D, mostly in rural churches. Unlike the pattern observed of simple SG, groups of more than three elaborate SG per monument have been observed in this region: eight in CYP008, 11 in CYP021, six in CYP023 and five in CYP032 (Table 1). Moreover, in many cases elaborate SG in the same church had many stylistic similarities that imply the same carver or the depiction of a specific event (by one or multiple carvers). Apart from the groups discussed above (eight 16th-century ships in CYP008, seven ships of a similar date on the western wall of CYP021, two 15 th- or 16th-century round ships on the north interior wall of CYP034 and two galleys in CYP032), three or five 19th-century such ships have been published from CYP029 and three from CYP036 (Imhaus, 2001); all but one (CYP034_S02_D01) (Fig. 18b) are carved on previously undecorated surfaces. This is a pattern that most elaborate SG follow: they were carved on undecorated walls and away from the sanctuary or altar.

These groups of elaborate graffiti demonstrate particular attributes. The carvers seem to have had plenty of time to work on plain plastered walls, where large-sized ship drawings could be accommodated. In many cases, the intention to depict specific ships or specific events is also obvious, as the carvers emphasized details that they considered important: see for example the possible effort to correct the rigging in CYP001_S01_D02 (Fig. 2), or the rowing system in CYP021_S04_D15 (Fig. 13a). Such details may be indicative of people with first-hand experience of the ships, either seamen or passengers, obviously with some artistic talent.

Twelve SG, depicting ships of possible western Mediterranean origin comprise a particular sub-group of the elaborate SG: CYP008_ S01_D01, D02, D03, D04, D05 (Fig. 10); CYP008_S03_09, CYP008_S02_10, (Fig. 11); CYP021_S04_D15, D28 and D31 (Fig. 13); and CYP034_S01_D01 and D02 (Fig. 18b), all in Famagusta D. It is very tempting to suggest that the creators of these SG were somehow associated with ships that came to Cyprus from overseas. According to traveller's accounts, such ships stopped over at all four harbours along the south coast: Paphos, Limassol, Larnaca, and Famagusta. Yet, the last two were undoubtedly the main ports of the specific route; this is where ships anchored for longer periods and travellers disembarked for sightseeing or pilgrimage to monasteries and places of cult (Grivaud, 1990: 2325; Marangou, 2002: 92-93, 194-195). As a result of the flourishing maritime activity, the hinterland of the coastline between Larnaca and Famagusta must have 


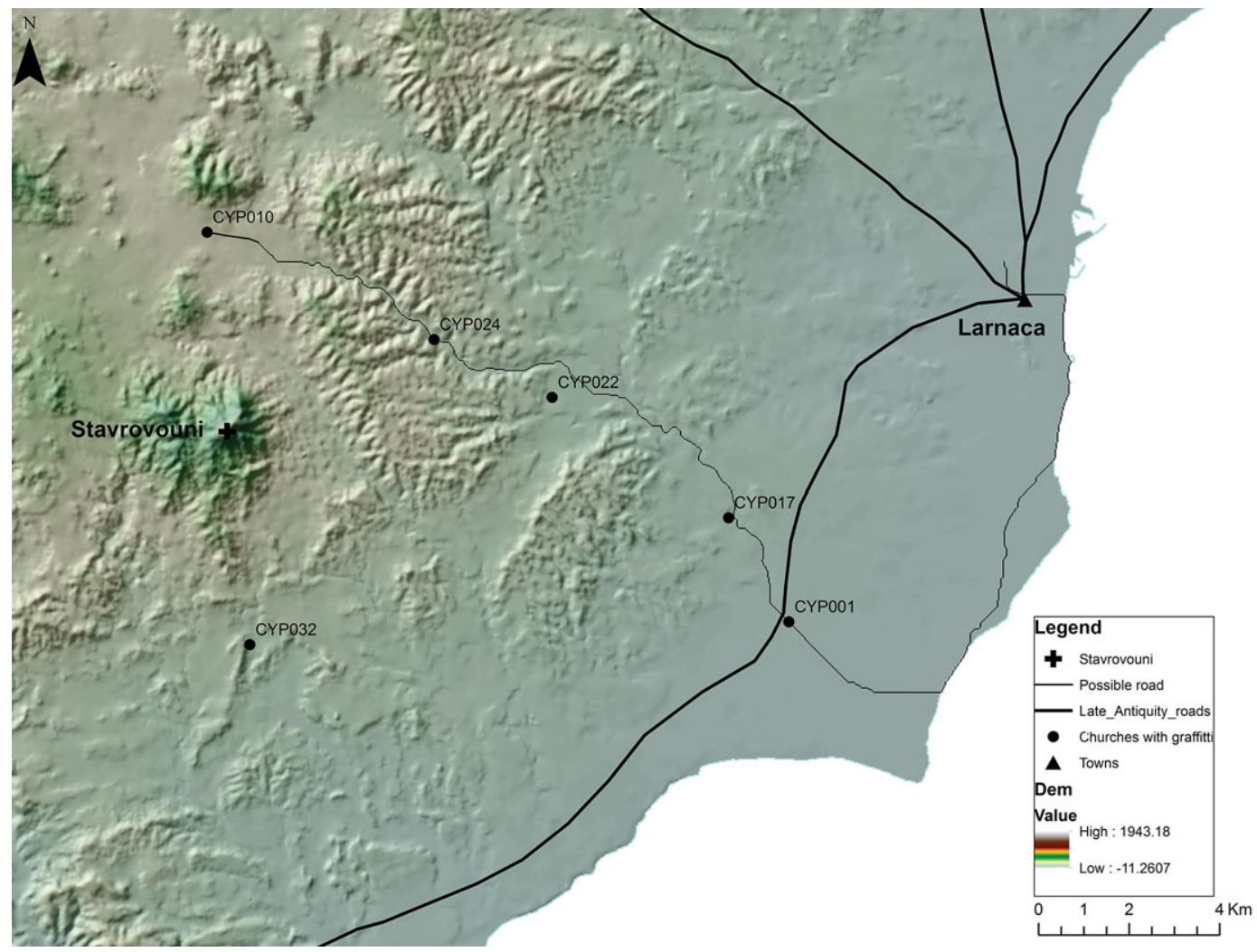

Figure 20. The location of five graffiti-monuments in Larnaca District, marking a path from Larnaca to Pyrga, possibly associated with Stavrovouni monastery: Panagia Aggeloktisti (CYP001), Church of Saint George of Arpera (CYP017), Mosque of Klavdia (old Byzantine Church of Saint Ekaterina), (CYP022), Monastery of Panagia Stazousa (CYP024) and Royal Chapel of Saint Catherine (CYP010) (Map and GIS by Niki Kyriakou, University of Cyprus).

significantly benefited from sailors and travellers, often pilgrims to the Holy Land, interested to explore the nearby sights. Due to the absence of hostels and inns, visitors were obliged to sleep out, often in the open, as reported in an early account of 1394 by Nicola Martoni (Cobham, 1908: 25). In this context, we know that rural monasteries and churches, commonly located in the proximity of village settlements and cities, served an array of functions and services (Bakirtzis, 2013). They housed relics and burials associated with local cults attracting visitors and pilgrims. In this capacity, monastic communities provided shelter for daytime rest or overnight stays. The existence of SG in these sites certainly indicates the movement of people following routes associated with popular local cults. Meinardus (1970-1972: 31) having documented numerous SG far from the coast, in the Balkans, Anatolia, the Aegean islands, and Cyprus, suggested that: 'either individual sailors, or more probably whole crews, attended certain panegyri in order to receive blessings of protection for their maritime undertakings'. He also assumed that the SG he found in churches at the medieval Armenian capital of Ani, in the modern Turkish province of Kars, 'hundreds of miles from the nearest coastline' (Meinardus, 1996-1997: 316), were carved when 'some crews may have gone on a pilgrimage to Ani'. Focusing on the elaborate ships associated with western types, located on the rural churches of Cyprus, we suggest that the presence of SG point to the presence of established routes of pilgrimage aimed mainly for visitors stopping in Cyprus. Although this remains a hypothesis, it could help explain why small rural churches, with no known association with the sea or related cults, were chosen for the carving of elaborate $\mathrm{SG}$, in preference to churches in the villages.

Following this conceptual thread, the presence of SG might help understand the role of rural monuments located on roads or footpaths (see also BekkerNielsen, 2004); for example, the locations of CYP001, CYP010, CYP017, CYP022 and CYP024 could be on a path that connected Larnaca with the periphery of Stavrovouni monastery (Fig. 20). Similarly, the three monuments with western ships (CYP008, CYP021 and CYP034) mentioned above, could be located on a road connecting Larnaca and Famagusta; at least five other graffiti-monuments are on the same route (CYP011, CYP020, CYP023, CYP026 and CYP033) (Fig. 21). Seamen or ship passengers, locals or foreigners, may have spent time praying inside these churches, or just resting outside, lying sheltered by their walls. Some of 


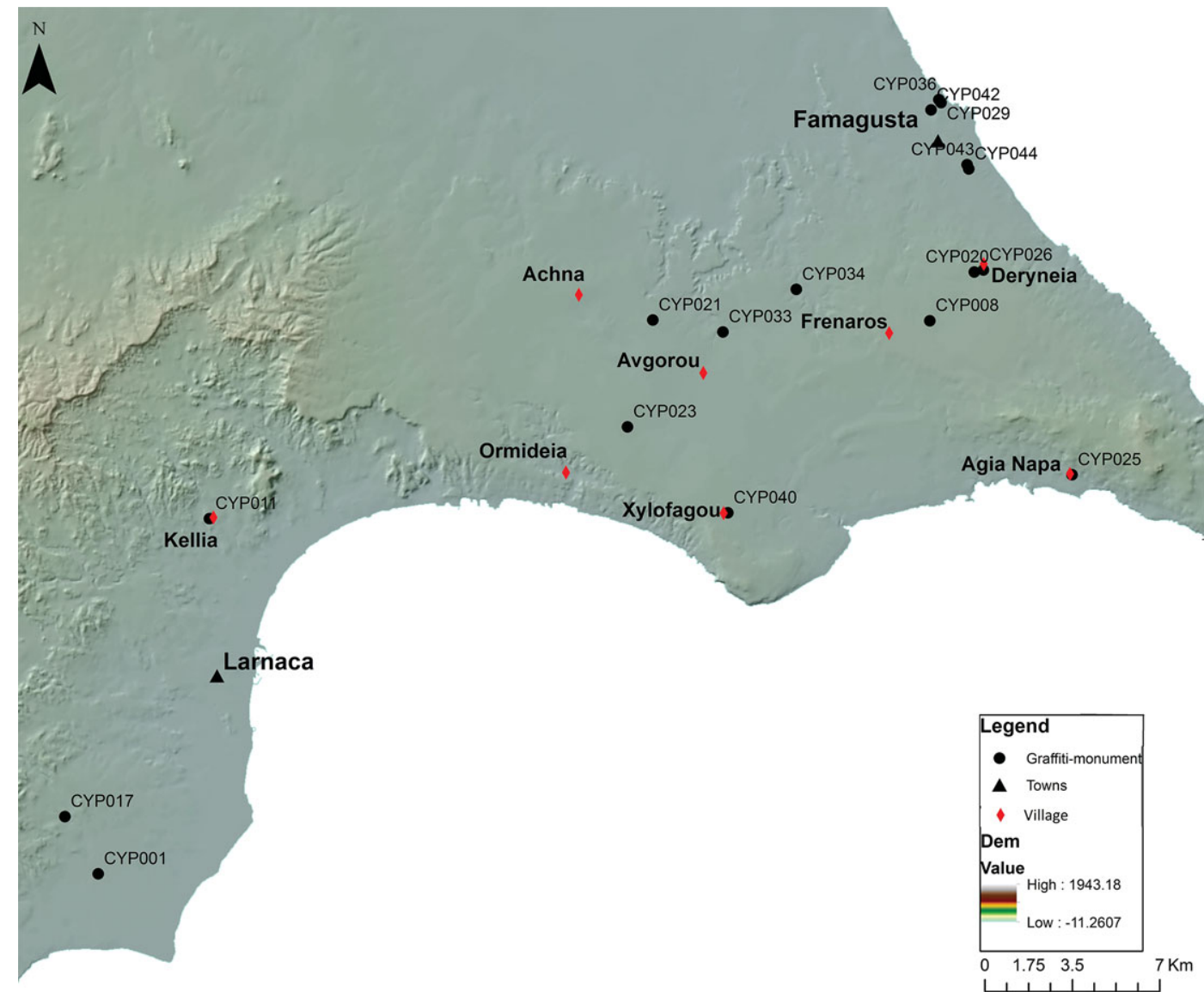

Figure 21. The location of the graffiti-monuments in Larnaca and Famagusta Districts, possibly associated with a road that connected the two harbours. Most are rural churches - the red lozenges mark the villages (Map and GIS by Niki Kyriakou, University of Cyprus).

them with a bit of artistic talent might have drawn ships on the walls. Although it is difficult to tell whether these SG could be interpreted as 'the poor men's votive ships' (Westerdahl, 2013), just the work of 'ship-lovers' (Basch, 1987: 230) or both, it is important to consider the context in which SG were created.

An instructive example is offered by the domed church of St George Teratsiotis (CYP021) (Fig. 12). The rural location of the church indicates the existence of a busy road connecting Avgorou villages with the area of Achna (Fig. 21), also part of the network connecting the ports of Larnaca and Famagusta. Its auspicious location in a fertile plateau and the presence of water sources point to the likelihood that it served as an overnight stop for travellers and pilgrims. The quality as well as the number of graffiti suggest that visitors not only had access to the church but also took the necessary time to mark their passage at what appears to have been a cult site cared for by a monastic community, which benefited from the flow of pilgrims.

In terms of the site's topographical relation to Avgorou village, it is worth mentioning the curious absence of graffiti from the late 15th-century barrelvaulted church of St George, situated in the heart of the settlement. The lack of graffiti in the village church is not coincidental but points to the significance and possible role of sites located on the outskirts of settlements. If the village itself was not directly part of the aforementioned pilgrimage network, travellers might be intentionally funnelled to the periphery of the village, where monasteries, including Teratsiotis, regulated access to local cult sites and provided accommodation.

\section{Ship graffiti and inscriptions}

The graffiti phenomenon on the island could be better understood if textual graffiti (inscriptions) were also taken into consideration, since they provide more telling insights into the identity of their carvers than pictorial ones.

Graffiti written in Latin are mainly commemorative, containing the author's name and sometimes also the date of the visit to the site. The earliest such evidence on the island dates to the 12th to the beginning of 13th centuries and is found in the churches of Saint 
Sophia in Nicosia (CYP035) and Panagia tou Araka at Lagouderà (Trentin, 2010: 308-312). In fact, the vast majority of the Latin inscriptions date from the 12th to the 17 th centuries, that is the period when the island was under the Lusignans and the Venetians, as well as the early days of Ottoman rule.

Textual graffiti written in Greek began to appear from the 15th century onwards and became more popular during the 18th and 19th centuries; the only exception known thus far is the inscription in red pigment under the ship dipinto of CYP011 (Fig. 8b), which may date back to the 12 th-13th centuries. Greek graffiti are mainly commemorative and quite explicit, stating not only the author's name but also the date, title, or provenance.

In most of the graffiti-monuments surveyed during the KARAVOI project ( 27 of 44 ) both SG and inscriptions have been found (Table 1) (Fig. 19). Of these, in 16 cases the inscriptions were written in Greek, three in Latin, and in eight both Greek and Latin inscriptions were documented. It is notable that none of the 11 graffiti-monuments with Latin inscriptions is located in Paphos D. One of them, Kolossi Castle (CYP010) is in Limassol D, and another, Bellapais Abbey (CYP028), in Kyrenia D. All the rest are located close to either the two harbours of Larnaca and Famagusta, or the capital, Nicosia. In contrast, the distribution of the 24 monuments with Greek inscriptions is much wider, covering the entire surveyed part of the island.

Textual graffiti in Latin and Greek also follow different patterns regarding their place in churches: Greek inscriptions are found on sacred surfaces in the churches, close to wall paintings of saints and in the sanctuary (CYP011, CYP021), whereas the Latin ones are usually found in less auspicious spaces, such as the exterior walls (CYP024), and certainly away from the sanctuary (for example CYP025, CYP028 and CYP036 in the catalogue, see Appendix). This may indicate a different approach between Greek and Latin speakers (that is Orthodox and Latin Christians) towards the monument as a sacred place: the Latin speakers' intention was mainly to affirm their presence at the monument, as a kind of a presence or identity mark, whereas the Greeks tried to establish an intimate relationship with the sacred (Trentin, 2010: 302-303).

\section{Conclusions}

A most important result of the KARAVOI project has been the creation of a comprehensive corpus of ship graffiti on Cyprus, a repository of key information, to which more data can be added in the future. This body of primary evidence will serve as the basis for, and will be enhanced by further research into the maritime history and archaeology of the Medieval period on the island, which has largely escaped the attention of scholars. Moreover, the holistic analysis attempted during this project demonstrated the importance of contextualization in the study of SG. Beyond their significance as a source of ship iconography, when examined with regard to the graffiti phenomenon in general, and the spatial features of the monument they are found on, at a local and a regional level, SG can provide insights into very particular aspects of the maritime landscape, such as the behavioural associations of seamen when on land, or the extent that specific groups of the population were involved in nautical activities.

Although the survey was not exhaustive, the 233 documented SG are representative of the character and the duration of the practice of carving ships on Cyprus. This practice was clearly associated with religious monuments, churches and mosques, unlike the case in other Mediterranean areas, especially in the west, where numerous SG have also been recorded on non-religious public buildings (for example Carpentier et al., 2001; Rivera-Collazo, 2006; González Gozalo and Font, 2007). Despite their common placement, the typological analysis of the ships indicated differences regarding both their distribution and their creators. This diversity was expressed through the degree of the drawings' complexity, the typology of the depicted ships, the place of the graffiti in the monuments, and the location of these sites on the island.

The 83 elaborate SG of the corpus, as expected, have been rich in information. The earliest ones, dated to the 16th-17th centuries, depict mostly ship types of western origin, such as round ships, galleons, cogs, and carracks, whereas the ones dated in the Ottoman period depict sailing ships and galleys with typological features common in the eastern Mediterranean. In this article, particular emphasis was given to the former category, the distribution of which seems to present interesting patterns. The monuments with such SG were small rural churches, outside the main settlements, but close to the two main harbours of the island, Larnaca and Famagusta. In these areas inscriptions in Latin have also been located; moreover, both Latin inscriptions and early elaborate SG were found in similar places in the monuments: mostly on plain walls, close to the doors and away from the sanctuary. This analysis has allowed us to suggest that such SG might mark the itineraries of visitors, seamen or passengers, who travelled on the island while their ships were moored in the harbours, and stopped to rest or pray at small rural churches with no other known maritime associations. Different itineraries to important religious centres, such as the Stavrovouni monastery, could be also be detected from the location of monuments with simple or elaborate SG dated in later periods.

The documentation of simple SG, which are roughly executed, of uncertain date and hard to classify, has not attracted much scholarly attention, possibly because few simple boat drawings on the walls of common 
churches could seldom have been considered sufficient material for a publication. During the KARAVOI project, however, 80 such SG were found and mapped in 32 different monuments, mostly churches. A lot of them were carved in the sanctuary or on wall paintings, locations where Greek inscriptions have also been found; this might be indicative of their association with the local population, although visitors could also have carved simple ship drawings. Still, the fact that they are almost omnipresent on the island, even in monuments located in the mountains, demonstrates that Cypriots might have carved many of them. The simplest among them could be Christian symbols, but others could be votive or tokens of religious communication associated with specific maritime ventures. If so, their significant number could be a testimony of an indestructible level of maritime life' in Cypriot waters, and 'the inconspicuous activity that continued even in periods of depression' (Braudel, 1973: 146-147), which is otherwise rather absent in the archaeological record.

The lack of large-scale SG studies elsewhere in the Mediterranean has prevented a comparative analysis with the Cypriot SG, something that could undoubtedly shed more light on many issues beyond ship iconography, as discussed above. Nonetheless, it has become clear that spatial analysis of SG at a micro and macro scale is fundamental to their contextualization at a local — within the monumentand regional level. It contributes to the interpretation of their character and meaning, and provides valuable insights into the identity and behaviour of their creators. Their interpretation after such analysis, conjectural as it may be, marks one of the fundamental idiosyncrasies of graffiti as a primary source of information: despite their limitations and fragility as hard material evidence, they reflect very personal and subjective expressions of the past.

\section{Acknowledgements}

The KARAVOI team is grateful to the A.G. Leventis Foundation for funding the project through the Leventis Foundation Research Committee of the University of Cyprus. Equally, thanks are owed Dr Marina Solomidou-Ieronymidou, Director of the Department of Antiquities of Cyprus, for issuing the permit and supporting the project. The authors are indebted to the rest of the KARAVOI team members: Despina Papacharalambous, the Cyprus Institute, for bibliographical references for Byzantine monuments of Cyprus; Ropertos Georghiou for RTI photography, and Dante Abate and Marina Faka for laser scanning, both from the Cyprus Institute; Lefkothea Papakosta, MA student, University of Cyprus for digitization the SG and preparing the figures and Barbara Stivarou for her work on the data base. We are also grateful to Dr Brunhilde Imhaus who kindly gave permission to digitize her drawings from her survey in the occupied areas of Cyprus. and to Dr Eleni Prokopiou for informing us about the graffiti in CYP032. We also thank the anonymous reviewers for providing meaningful comments that helped us improve this manuscript and clarify the way we described our work and ideas on Cypriot ship graffiti.

\section{Notes}

1. The Greek word Karavos (Kó $\rho \alpha \beta o \varsigma)$, used in some Byzantine sources as a synonym for $\pi \lambda o i o$ or $\sigma \kappa \alpha \dot{\alpha} \varphi \varsigma$, means ship (Koukoules, 1952: 365).

2. The division of the monuments per District follows the modern administrational division of the Republic of Cyprus.

\section{Appendix: Catalogue of graffiti-monuments surveyed for the KARAVOI project}

CYP001 Latin Chapel of the Church of Panagia Angeloktisti, Kiti, Larnaca District (see text).

CYP002 Palaea Enkleistra of St Neophytus, Souskiou, Paphos District. A cave chamber with a tomb recess in the east wall. It was used as a hermitage and almost all surfaces are decorated with frescoes dated to the 15th century (Stylianou and Stylianou, 1985: 397-403; der Parthog, 2006: 75-76). Nine SG were found on the wall of the tomb (Fig. 5a) and one airplane on the ceiling of the southern part. More graffiti were also recorded: stars, two stylized animals (a fourfooted animal [horse?] and a fish), several inscriptions in Greek (probably 19th-20th century) and one in Arabic.

CYP003 Church of Saint George, Acheleia, Paphos District. The church was built in the 16th century, but the latest phase is dated to the 18th century, as testified by an inscription (1724) (Stylianou and
Stylianou, 1985: 409-413; der Parthog, 2006: 64-65). S. Demesticha documented 12 ship graffiti in 1995, all on external walls: five on the apse and eight on the western most section of the southern wall (Fig. 4). When the KARAVOI team visited the monument in 2016, four of the graffiti on the apse and two of those on the south wall had been destroyed. On the southern wall and in the same area where SG were documented, a rosette motive is also carefully carved, possibly with a compass.

CYP004 Church of the Archangel Michael, Choli, Paphos District. A barrel-vaulted building with a taller, tower-like narthex, built and decorated in the early 16th century (Stylianou and Stylianou, 1985: 419-421). Two SG were found on the frescoes of the sanctuary apse; one between Saint Basil and Saint Epiphanius, and one between Saint Spyridon and Saint Gregory. More graffiti were recorded on the 
apse: Greek inscriptions, both scratched and traced on the plaster with charcoal, most from the 18th century; one with a date: $1776 \varphi \varepsilon \beta \rho o v \alpha \rho \iota / o 5 ~ 28$;

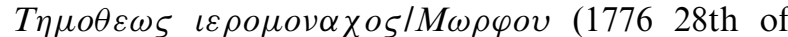
February; Timothy, monk from Morphou). Several Greek inscriptions copy the painted names of the saints. Tripartite-ending crosses, stylized animals and human figures (one representing a priest) are close to numerous abstract geometrical composition such as stairs, lattices, and zig-zag forms.

CYP005 Church of Panagia Chryseleousa, Emba, Paphos District. A cross-in-square church, built in the early 12 th century and decorated in the late 15 th century. The narthex was added in 1744 (Stylianou and Stylianou, 1985 409-413; der Parthog, 2006: 106 107). Three interior $S G$ were documented on the south wall of the western section of the narthex and one exterior, over the door on the north wall.

CYP006 Church of the Dormition of the Mother of God, Kourdali, Troodos, Nicosia District. Threeaisled basilica with a tiled roof. Built and decorated in the 16th century, it was renovated in 1921 (Stylianou and Stylianou, 1985: 141-150; der Parthog, 2006: 195-196). Two SG were found on the interior of the sanctuary: one on the feet of Cyril and the other on the south wall of bema.

CYP007 Castle of Kolossi, Limassol District. Built in 1454 by Luis de Magnac, Grand Commander of the Knights of Saint John of Jerusalem (Aristidou, 1983; Enlart, 1987: 494-502; der Parthog, 2006: 130-131). In 1995 Demesticha documented three ship graffiti on the first floor, two on the east wall and on the south. When the KARAVOI team visited in 2016, they had all been destroyed. Other graffiti are still preserved, however (der Parthog, 2006: 131): Latin inscriptions, identity marks, coats of arms, and decorations traced with red colour. One inscription preserves the date: 1477, 18 of October.

CYP008 Church of Saint Marina, Frenaros, Famagusta District (see text).

CYP009 Church of Archangel Michael, Monagri, Troodos, Limassol District. The monastery was founded between the 10th and the 12th centuries, was destroyed in 1735, and rebuilt in 1740. The church was decorated in 1745-1775 (Stylianou and Stylianou, 1985: 238; der Parthog, 2006: 155-156). On the exterior western wall four ship and more non-nautical graffiti have been recorded (Fig. 5b): Greek and Arabic inscriptions, human figures, rosette motives, and abstract compositions. Inside the sanctuary a poorly preserved Greek inscription was also found.

CYP010 The so-called 'Royal Chapel' of Saint Catherine, Pyrga, Larnaca District. A small, singlespace, barrel-vaulted structure with no apse, built and decorated in 1421 and 1432 (Stylianou and Stylianou, 1985: 429-432; Enlart, 1987: 325-334; der Parthog, 2006: 305-306; Papageorgiou, nd). Imhaus (2001: 185-186, fig. 8) recorded three ship graffiti, two of which she later interpreted as a fragata (Fig. 6d) and its tender (Bollon and Imhaus, 2009:426, fig. 5). The KARAVOI team recorded three more uncertain SG. The textual graffiti of the monument have been extensively published (Schryver and Schabel, 2003; Trentin, 2010). They are mainly commemorative inscriptions in Latin dating back to the 15th-18th centuries. Only one Greek inscription and a few figurative graffiti (human figures and coats of arms) were also found.

CYP011 Church of Saint Antony, Kellia, Larnaca District (see text).

CYP012 Church of Panagia Chryssopolitissa, Erimi, Limassol District. A cruciform, domed church (unpublished). Two SG have been recorded on the exterior walls of the apse. On the interior south wall, close to the frescoes of Saint Marina and Saint Damianos, some Greek inscriptions are preserved; among them two dates: 1728 and 1777. Furthermore, in the small niche of the south wall, there is an indication of damnatio memoriae on the quite damaged figure of two saints: a clear horizontal scratch runs across their necks.

CYP013 The House of the Dragoman Hadjigeorgakis Kornesios, Nicosia is a two-floored manor extensively remodelled in the 18th century, built on existing structures dating back to the late Medieval period (Rizopoulou-Egoumenidou, 1991). Three SG were recorded on the preserved plaster of the western room connected to the central hall, on the upper floor. On the same wall, several figurative graffiti are mixed together with Greek inscriptions dating from the second half of the 18th century.

CYP014 Church of Saint Marina, Mari, Larnaca District. Possibly dated to the 15th century (Antoniadis, 2011: 182-184). Four SG were recorded on the interior: one on the western and three on the southern wall (Fig. 5c).

CYP015 Church of Apostle Luke, Skarinou, Larnaca District, possibly dated to the 19th or 20th century (unpublished). Four SG were found on the exterior north wall.

CYP016 Church of Saint Marina, Psemmatismenos, Larnaca District. A single-aisled church, built in the 16th century (Gunnis, 1936: 406) and with extensive renovations in its western part in 1886 (Antoniadis, 2011: 267). In 1995 Demesticha documented two SG on the exterior of the apse. When the KARAVOI team visited the monument in 2016, they were both almost destroyed. Two inscriptions in Greek were also present on different ashlar blocks of the same wall: one preserves the date 1885 , while the other, traced with accurate capital letters, is probably, earlier.

CYP017 Church of Saint George of Arpera, Tersefanou, Larnaca District. Single-aisled, barrelvaulted church, built in 1745 , according to an inscription in the interior (Vasileiou, 2011). Nine SG were recorded from the exterior: nine on the south wall and one on the apse. More fragmentary graffiti 
are present: human figures, geometrical shapes, and Greek inscriptions.

CYP018 Church of Saint Nicolas, Philousa, Kelokedara, Paphos D. Only the church is preserved from the monastic complex: a single-aisled building covered with a wooden roof (unpublished). One SG was found on the exterior north wall. More fragmentary graffiti, such as Greek inscriptions and geometrical forms, are present on the same wall.

CYP019 Monastery of Saint Panteleimon Ahera, Mitsero, Nicosia District. Built in the 18th century according to an inscription over the western entrance. One dipinto in red colour was found on the exterior south wall, also published by Imhaus (2001: 186, fig. 10).

CYP020 Church of Panagia, Deryneia, Famagusta District. It was initially built as a single-aisled, domed structure in the 14th or 15th century, but the nave, the mezzanine and the south part of the sanctuary were added during repairs in 18th century (Gerasimou et al., 2001). Two SG were found on the exterior northern wall (Fig. 5d).

CYP021 Church of Saint George Teratsiotis, Avgorou, Famagusta District (see text).

CYP022 Mosque (old Byzantine Church of Saint Ekaterina), Klavdia, Larnaca District. Single-aisled vaulted church, built possibly at the end of 15 th or beginning of 16th century, it was turned into a mosque after 1571 (Antoniadis, 2011: 143-144). Two SG were found on the interior, on the pillars between the main building and the north nave, and two outside the western entrance (see also Michail, 2015: 50). Other graffiti are also present, close to SG on the external west wall, the external part of the apse and inside the church: very fragmentary inscriptions in Arabic and Greek, a human figure, and geometrical abstract compositions (for the symbols see Ozcàriz Gil, 2007: 75-76; Trentin, 2011: 205-206).

CYP023 Church of Saint George of Angona, Ormidheia, Larnaca District (see text).

CYP024 Monastery of Panagia Stazousa, Pyrga, Larnaca District. The main Gothic style church is dated to the 14th century (Enlart, 1987: 321-325; Antoniadis, 2011: 282). On the northern exterior wall, five ships were found together with more graffiti: Latin and Greek inscriptions, dated from the end of the 17th century until the modern times, and geometrical forms, such as circles, and a rosette motif. Greek inscriptions are also carved on the vaulted main entrance to the monastery, together with human figures and knives. Inside the building, on the east wall of the nave, there are two Latin inscriptions: one contains just two capital initials (A.M.), while the other one has a name and the beginning of a date (17..).

CYP025 Monastery of Agia Napa, Famagusta District. The church possibly dates to the 8th or 9th centuries, with a new section added in the 14th century. The monastery was founded in the 15th or 16th century and was completed in 1570 . The monastery fell into disuse in 1790 for unknown reasons. The church is built around an underground rock-cut chamber, which incorporates a Latin chapel (Enlart, 1987: 317-318; der Parthog, 2006: 323-324). On the northern wall of the basement one dipinto in black was recorded, published also by Imhaus (2001: 186, fig. 9). Greek and Latin inscriptions traced with black charcoal or scratched are also visible, some with names and dates (such as 1625-1788). Latin inscriptions, one of a date (1485) were also found on an ashlar block, by the entrance of the cloister.

CYP026 Church of Saint George, Deryneia, Famagusta District. A small, single-aisled, domed church, built in the 16th or 17th century (unpublished). Three SG were found on the exterior northern wall.

CYP027 Church of the Panagia Amirou monastery, Apsiou, Limassol District. A single-aisle with a wooden roof church, possibly built in the 15th or 16th century. Eleven SG were recorded from the exterior: ten on the apse and one the on the southern wall (Fig. 5e)

CYP028 Bellapais Abbey, Kyrenia District. A Gothic style monastery complex, founded in $c .1200$ (Megaw, 1959; Enlart, 1987: 174-200). Imhaus (2001: 180, fig. 2) published the photographs of five graffiti from the refectory, on the splay of the second window under the pulpit: four ships and a fish (for the ships there is also reference in Trentin, 2010: 304, fig. 14.2). In the archive of her drawing in the Department of Antiquities three more elaborate graffiti from the Chapterhouse were found.

CYP029 Church of Saint George of the Greeks, Famagusta. A church in the French Gothic style of the Frankish period, which combines a Gothic basilica with a Byzantine dome. It fell into disuse at the time of the siege of Famagusta by the Turks in 1571 (Enlart, 1987: 253-258; der Parthog, 2001: 322). Imhaus (2001: 180-185, figs 3-6) refers to 'more than 50 graffiti', but she recorded 45 and documented 29, because some of them were carved too high on the walls. They were mostly found on the north wall of the first, fourth, and fifth bays of the nave. Walsh (2007) discussed the ship graffiti and their context. He dated one ship, not previously recorded by Imhaus, to the 16th century (Walsh, 2007: 120, fig. 5) and discussed in passim at least seven more that were also published by Imhaus, one of them in detail: a mid 19th-century brig, fully rigged, with Ottoman flag at the stern (Fig. 6b, c) (Imhaus, 2001: 182, no 2; Walsh, 2007: 120, fig. 5).

CYP030 Church of the Holy Apostles, Pera Chorio Nissou, Nicosia District. Built and painted between 1160 and 1180 with some repainting in the 15 th century (der Parthog, 2006: 278-280). Trentin documented a simple graffito of a two-masted ship on the apse of the sanctuary (Trentin, 2007: 458459 , table 4). Very fragmentary Greek inscriptions were also found in the sanctuary. The only Latin 
inscription, recorded on the south wall, is a namePetrus - probably dated to the 13th century (Trentin, 2010: 308).

CYP031 Church of the Holy Cross, Pelendri, Troodos, Limassol District. A three-aisled domed structure. Originally, a single-space building, built in the middle of the 12th century. The apse was integrated into a new building at the end of the 13th/beginning of the 14th century. The north aisle was added before the middle of the 14th century, while the south aisle was added in the 16th century. Frescoes are from the 12th century (1178) and it was redecorated in the 14th century (Stylianou and Stylianou, 1985: 223-232; der Parthog, 2006: 155-156). One SG was recorded on the apse of the sanctuary, close to very damaged and fragmentary Greek inscriptions, some stairs, and geometric compositions.

CYP032 Church of Athanassios and Cyril. Larnaca District (see text).

CYP033 Church of Saint Marina, Avgorou, Famagusta District. A single-aisled, vaulted church built probably in the 12th century (Pavlidis, 1991: 312). One SG was recorded on the interior northern wall, next to an illegible Greek inscription.

CYP034 Church of Panagia Asprovouniotissa, Frenaros, Famagusta District (see text).

CYP035 Selimiye Mosque, three-aisled Gothic Cathedral of Saint Sophia, Nicosia (Enlart, 1987: 82-130). Imhaus had recorded one SG on the external walls and ten inside the building (Figs. 5e; 6a) and on the marble slabs of the floor (see also Bollon and Imhaus, 2009: 425-426). There are also coats of arm and Latin inscriptions ascribable to the 13th-16th century.

CYP036 Lala Mustafa Pasha Mosque, Gothic cathedral of Saint Nicolas, Famagusta (Enlart, 1987: 222-245). Imhaus (2001: 185, fig. 7) recorded four ship graffiti on the interior walls: over the south door and on a fresco fragment of the western wall.

CYP037 Church of Saint George Nikoxylitis Monastery, Droushia, Paphos District. Possibly built in the 16th century (unpublished). Two SG were recorded on the exterior: one on the southern wall and one the on the apse.
CYP038 Church of Saint Menas (new), Neo Chorio, Paphos District. A 20th-century church in the centre of the village. Two SG were found on the exterior southern wall.

CYP039 Ahmet Subaşi mosque, Chrysochou, Paphos District. Single-aisled, barrel-vaulted converted medieval chapel dating from the 15/16th century (Bağışkan, 2009: 347-349). One SG was found on the eastern exterior wall.

CYP040 Church of Saint George, Xylophagou, Famagusta District. A single-aisled vaulted church, built and decorated in the late 15th century and renovated in 1770, with some later painting (Stylianou and Stylianou, 1985: 438-439; der Parthog, 2006: 314-315). Six SG were recorded on the exterior: two on the northern wall and two on the apse. Inside the church, in the sanctuary and on the south wall, there are Greek inscriptions and monograms, as well as geometrical figures and criss-cross patterns.

CYP041 Mosque in Pelathousa, Paphos District (unpublished). Small single-space structure with a northern annex. Originally, the 16th-century chapel of Saint Catherine. One SG was found on the western door jamb.

CYP042 Famagusta walls. The Venetian fortifications improving the existing Frankish defences of the city were almost completed by the $1560 \mathrm{~s}$. After the siege of 1571 several repairs were done by the Ottomans. Imhaus has provided information about the existence of ship graffiti on the walls but she had not recorded them.

CYP043 Church of Saint George Farangou (unpublished). Domed cruciform 12th-century chapel later extended in its west part and along its north side with a barrel-vaulted annex. One SG was recorded by A. Foulias and $\mathrm{Ch}$. Chistodoulou on the interior western wall.

CYP044 Church of Saint Panteleimon, Varosia, Famagusta D. Single-space medieval chapel with 20th-century western extension. Four SG were recorded by A. Foulias and Ch. Chistodoulou in the interior: three in the sanctuary and one on the southern wall.

\section{References}

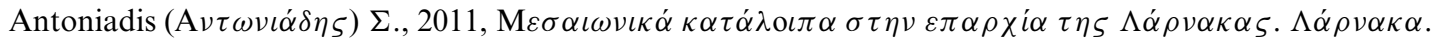

Arduini D. and Grassi C., 2002, Graffiti di navi medievali sulle chiese di Pisa e Lucca. Pisa.

Aristidou, E. C., 1983, Kolossi Castle through the Centuries. Nicosia.

Artzy, M., 1999, Carved ship graffiti-an ancient ritual? in H.E. Tzalas (ed.), Tropis V: 5th International Symposium on Ship Construction in Antiquity: Nauplia 26-28 August 1993, 21-27. Athens.

Auger-Sergent, A. S., 1996, Les graffitis à sujets maritimes en Normandie (du XIIe au XIXe siècle). Cahier Havrais de Recherche Historique 55, 53-69.

Babuin, A. and Nakas, Y. D., 2011, Byzantine ship graffiti from the church of Prophitis Elias in Thessaloniki. Skyllis 11.1, $8-17$.

Baird, J. A., and Taylor, C. (eds), 2011, Ancient Graffiti in Context. New York.

Bağışkan, T., 2009, Ottoman, Islamic and Islamised Monuments in Cyprus (translation T. A. Sinclair). Nicosia. 
Bakirtzis, N., 2013, Locating Byzantine Monasteries: Spatial Considerations and Strategies in the rural Landscape, in C. Nesbitt and M. Jackson (eds), Experiencing Byzantium, 115-117. Aldershot.

Barrera Maturana, J. I., 2011, Barcos, peces, estrellas y otros motivos en los muros del castillo de Almuñécar (Granada), in XVIIe Colloque International De Glyptographie De Cracovie, du 4 Au 10 Juillet 2010, Organisé Par Le Centre International De Recherches Glyptographiques (CIRG), 27-46. Braine-le-Château.

Basch, L., 1978, Graffiti naval Grecs. Le Petit Peroquet 22, 41-46.

Basch, L., 1985, Les graffiti de Delos, in E.H. Tzalas (ed.), Tropis I. 1st International Symposium on Ship Construction in Antiquity, 17-23. Athens.

Basch, L., 1986, The Aegina pirate ships of c.B.C. 1700. Mariner's Mirror 72, 415-437.

Basch, L., 1987, Le musée imaginaire de la marine antique. Athens.

Basch, L. and Artzy, M., 1985, Appendix II. Ship graffiti at Kition, in V. Karageorghis and M. Demas (eds), Excavations at Kition V. The Pre-Phoenician Levels Areas I and II, part. 1., 322-336. Nicosia.

Bekker-Nielsen, T., 2004, The roads of ancient Cyprus. Copenhagen.

Benefiel, R. and Coleman, K., 2013, Graffiti, in W. Aylward (ed.), Excavations at Zeugma Conducted by Oxford Archaeology, 178-191. Los Altos, California.

Boetto, G., 2002, I graffiti navali del castello di Giulio II a Ostia antica. Archeologia Subacquea. Study, Ricerche e Documenti III, 409-417.

Bollon, M. and Imhaus, B., 2009, Graffiti marins de l'ile de Chypre, Report of the Department of Antiquities Cyprus, 423434.

Bonino, A., 1975, A medieval graffito at Final Ligure. The Mariner's Mirror 61, 291-292.

Bonino, M., 1978, Archeologia e tradizione navale tra la Romagnae il Po. Ravenna.

Braudel, F., 1973, The Mediterranean and the Mediterranean World in the Age of Philip II. New York.

Bucherie, L., 1992, Graffiti et histoire des mentalités, Genèse d'une recherché. Antropologia Alpina Annual Report 2, 41-64.

Bucherie, L. and González, E., 2000, Panorama des graffiti maritimes en Méditerranée, in Actes du XIe Colloque International de Glyptographie de Palma de Majorque, Centre International de Recherches Glyptographiques (CIRG), 31-99, Braine-leChâteau.

Burlet, R., 2005, Evolution de la Vogue sur les galères modernes, in T. Cortis and T. Gambin (eds), De Triremibus. Festschrift in Honour of Joseph Muscat, 553-584. Malta.

Carpentier, V., Ghesquière, E., Marcigny, C., Dubost, D. and Détree, J.-F., 2001, Graffiti marins et lecture ethnographique des comportements maritimes aux XVIIIe et XIXe siècles. L'exemple de 'Maltot' à Réville (Manche). Revue archéologique de l'ouest 18.1, 211-217.

Cassar, P., 1966, The nautical ex-votos of the Maltese Islands. Maltese Folklore Review 1.3, 226-231.

Christensen, A. E. J., 1995, Ship Graffiti, in O. Crumlin-Pedersen and B. Munch-Thye (eds), The Ship as Symbol in Prehistoric and Medieval Scandinavia, 180-185. Copenhagen.

Cobham, C. D., 1908, Excerpta Cypria: materials for a history of Cyprus; tr. and transcribed, with an appendix on the bibliography of Cyprus. Cambridge.

Damianidis, K., 2011, Roman Ship Graffiti in the Tower of the Winds Athens. Journal Archaeologisches Korrespondenzblatt 41, 85-99.

Damianidis, K., 2014, Study of ancient ship-graffiti from the Black Sea and the Aegean, in D. Couto, F. Gunergun, M.P. Redani (eds), Seapower, Technology and Trade. Studies in Turkish Maritime History, 450-459. Istanbul.

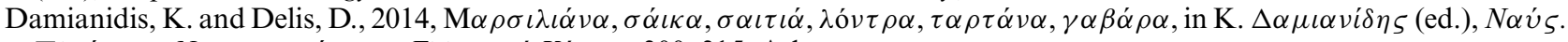

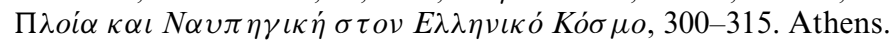

Darder i Mari, J. and González Gozalo, E., 2006, Els grafits de vaixells del molí d'En Moragues d'Alcúdia. IV Jornades d'Estudis Locals d'Alcúdia, 71-85.

David, M., 1965, Les graffiti des églises normandes. Archéologia 6 (septembre/octobre 1965), $28-41$.

Delouca, K., 1990, Inventaire des graffiti navals des églises byzantines et post-byzantines de l'ile d'Egine. D.E.A., Sorbonne-Paris I-Pantheon.

Delouca, K., 1996, Les graffiti de navires des églises byzantines et post byzantines de l'île d'Égine, in E. H. Tzalas (ed.), Tropis IV. 4th International Symposium on Ship Construction in Antiquity, 175-185. Athens

Delouca, K., 2000, Les graffiti de navires de l'Occident médiéval dans les monuments byzantins: l'exemple de Thesseion, in Utilis est Lapis in structura, Mélanges offerts a Leon Pressouyre, 373-377. Paris.

Demesticha, S., forthcoming, KARAVOI:A Programme for the Documentation of Ship Graffiti on Medieval and post-Medieval Monuments of Cyprus, in W. Ossowski (ed.), Proceedings of the International Symposium on Boat and Ship Archaeology 14, Gdansk.

der Parthog, G., 2006, Medieval Cyprus. A guide to the Byzantine and Latin Monuments. Nicosia.

Dhoop, T., Cooper, C. and Copeland, P., 2016, Recording and analysis of ship graffiti in St Thomas' Church and Blackfriars Barn Undercroft in Winchelsea, East Sussex, UK. IJNA 45.2, 296-309.

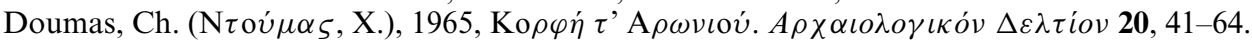

Dummer, E., 1685. A voyage into the Mediterranean Seas, containing by way of journal the views and descriptions of such remarkable lands, cities, towns, and arsenals, their several planes and fortifications, with divers perspectives of particular buildings which came within the compass of the said voyage: together with the description of 24 sorts of vessels of common use in those seas, designed in measurable parts, with an artificial shew of their bodies, not before so accurately done; finished in the year 1685. British Library, London, King's MS 40.

Emetz, I., 1995, Iconographic evidence for the ship of the Bosphorus kingdom. IJNA 24.2, 133-138. 
Enlart, C., 1987 (1st edn 1899), Gothic Art and the Renaissance in Cyprus. London.

Foulias, A. M., 2004, The Church of Our Lady Angeloktisti at Kiti, Larnaka: A Visitor's Guide. Nicosia.

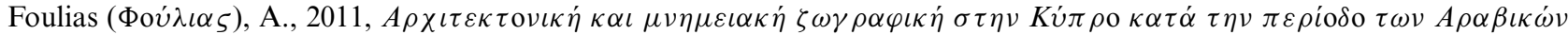
$\varepsilon \pi \iota \delta \rho \mathrm{o} \mu \omega \dot{\nu}$ (649-965). PhD Thesis, University of Athens, School of Philosophy Department of History and Archaeology, Athens.

Gardiner, R. (ed.), 1995, The age of the Galley. Mediterranean Oared Vessels since Pre-Classical Times. London.

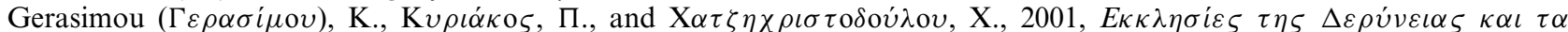

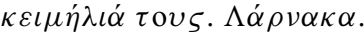

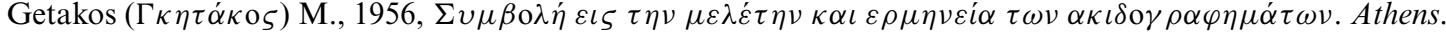

González Gozalo, E., 2006, Nuevos grafitos descubiertos en la torre del homenaje del Castillo de Bellver (Palma de Mallorca), in Actes du XVe Colloque International de Glyptographie de Cordoue, 161-178. Braine-le-Château.

González Gozalo, E., 2017, Nautical Graffiti in Mallorca. IJNA 46.2, 437-449.

González Gozalo, E. and Font, O. B., 2007, Los Barcos de Piedra. La Arquitectura Náutica Balear a Través de los Grafitos Murales (Siglos XIV-XVIII). Palma.

González, E. and Pastor, X., 1993, La arquitectura naval de los graffiti medievales mallorquines, in IV Congreso de Arqueología Medieval Española, Actas III, 1035-1047. Alicante.

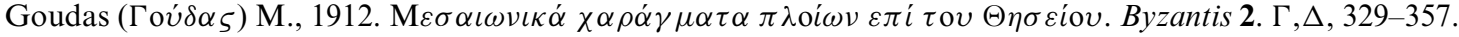

Grivaud, G., 1990, Excerpta Cypria Nova: voyageurs occidentaux à Chypre au XVème siècle. Nicosia.

Gunnis, R., 1936, Historic Cyprus: a Guide to its Towns and Villages, Monasteries and Castles. Methuen.

Helms, S. W., 1975, Ship graffiti in the church of San Marco in Venice. IJNA 2, 229-236.

Hermanns, M. H., 2010, 16th-Century ship graffiti on the Town Walls of Eivissa. IJNA 39.1, 66-75.

Hill, G., 1948, History of Cyprus, Vol. III. The Frankish Period, 1432-1571. Cambridge.

Imhaus, B., 2001, Graffiti marins de l'ile de Chypre, in Actes du XIIe Colloque International de Glyptographie de Saint-Christopheen-Brionnais, 177-189. Poitiers.

Jeffery, G., 1983 (1st edn 1918), A description of the Historic Monuments of Cyprus. Nicosia.

Kahanov, Y., 2011, Graffiti of ships in the Bahá'i Mansion at Mazra'ih, Israel. IJNA 15, 102-125.

Kahanov, Y. and Stern, E., 2008, Ship graffiti from Akko (Acre). The Mariner's Mirror 94.1, 21-35.

Kahanov, Y., Shotten-Hallel, V. and Cvikel, D., 2008, A graffito of a nineteenth-century armed ship from Akko, Israel. The Mariner's Mirror 94, 388-404.

Keegan, P., 2014, Graffiti in Antiquity. London, New York.

Koniordos, V. and Pelekanidou, E., 2001, Preliminary report on early post-byzantine ship's found in a cistern south of the Trigonian tower, in Tzalas, E. H. (ed.), Tropis VI: Proceedings of the Sixth International Symposium on Ship Construction in Antiquity. Lamia 1996, 331-339. Athens.

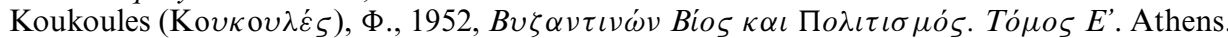

Landström, B., 1961, The Ship. A survey of the History of the Ship from the Primitive Raft to the Nuclear-Powered Submarine with Reconstructions in Words and Pictures. London

Langdon, M. K. and van de Moortel, A., 1997, Newly discovered Greek boat engravings from Attica, in J. Litwin (ed.), Down the River to the Sea: Proceedings of the Eight International Symposium on Boat and Ship Archaeology, 85-89. Gdansk.

Langner, M., 2001, Antike Graffitizeichnungen: Motive, Gestaltung und Bedeutung. Wiesbaden.

Le Bon, L., 1995, Ancient ship graffiti: symbol and context, in C.O. Pedersen and B. Thye (eds), The Ship as Symbol in Prehistoric and Medieval Scandinavia, 172-179. Copenhagen.

Malzbender, T. D. Gelb and Wolters, H., 2001, Polynomial Texture Maps, in Siggraph 2001: Proceedings of the 28th Annual Conference on Computer Graphics and Interactive Techniques, 519-528.

Marangou, A., 2002, The Harbours and Ports of Cyprus. Nicosia.

Megaw, A. H. S., 1959, A brief History and Description of Bellapais Abbey. Nicosia.

Meinardus, O., 1970-1972, Medieval navigation according to akidographemata in Byzantine churches and monasteries. $\Delta \varepsilon \lambda \tau i$ iov

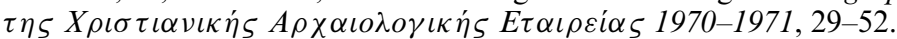

Meinardus, O., 1996-1997, Maritime testimonies in eastern Anatolia. Ani and Dogubayazit. Revue des Études Arméniennes 26, 316-320.

Michail, M., 2015, Ship graffiti in context: a preliminary study of Cypriot patterns, in I. Hadjikyriakos and M.G. Trentin (eds), Cypriot Cultural Details. Proceedings of the 10th Post Graduate Cypriot Archaeology Conference, 41-64. Oxford and Philadelphia.

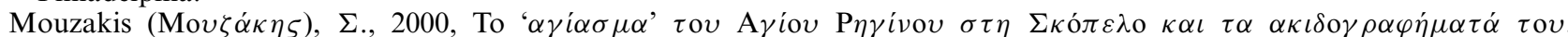
$\Theta \varepsilon \sigma \sigma \alpha \lambda \iota \kappa o ́ ~ H \mu \varepsilon \rho o \lambda o ́ \gamma \iota$ 37, 209-223.

Muscat, J., 1997, Graffiti on the exterior wall of St. Paul's Shipwreck church. Melita Historica 12, 179-194.

Murray, P. and Murray, L., 1998, The Oxford Companion to Christian Art and Architecture. Oxford.

Nakas, Y. and Krapf, T., 2017, Medieval Ship Graffiti from Amarynthos, Euboea, Greece. IJNA 46.2, $433-437$.

Ocharov, N., 1995, Légendes et rites maritimes reflètes dans le dessins graffiti des églises de Nassebar (XIV-XVIII), in H. Tzalas (ed.), Tropis III: 3rd International Symposium on Ship Construction in Antiquity, Athens 24-27 August 1989, $327-333$. Athens.

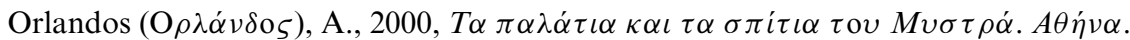

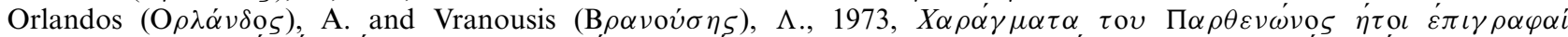

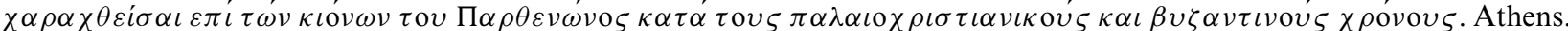

Ozcàriz Gil, P., 2007, Los grafitos de la iglesia del monasterio de la oliva. Navarra. 
Papageorgiou, A., nd, The 'Royal Chapel' of Pyrga: a Guide (Translation A. Stylianou). Nicosia.

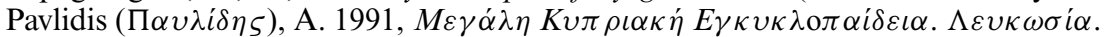

Pomey, P., 1992, Le Commandant Carlini et les études d'archéologie navale, in Récit d'une Aventure: les Graffiti Marins de Délos: Musée d'Histoire de Marseille, 18 Décembre 1992-22 Mars 1993, 25-47. Marseille.

Pomey, P., 2006, Les graffiti navals de l'Agora. Etude preliminaire. Anatolia Antiqua 14, 327-337.

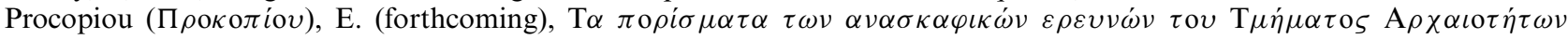

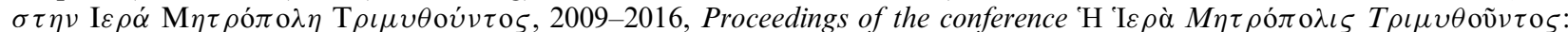

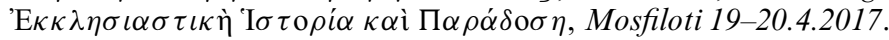

Pryor, J., 1988, Geography, Technology and War: Studies in the Maritime History of the Mediterranean, 649-1571. Cambridge.

Ray, L., 2001, The Art and Archaeology of Venetian Ships and Boats. Studies in Nautical Archaeology 5, College Station, TX.

Rivera-Collazo, C., 2006, Historical ship graffiti on the walls of San Juan's Spanish defense system: an interim report. IJNA 35.1, $41-52$.

Rizopoulou-Egoumenidou, E., 1991, The House of the Dragoman of Cyprus Hadjigeorgakis Kornessios. Nicosia.

Schaeffer, C., 1952. Enkomi-Alasia: nouvelles missions en Chypre, 1946-1950. Paris.

Schryver, J. G. and Schabel, C., 2003, The Graffiti in the 'Royal Chapel' of Pyrga. Report of the Department of Antiquities of Cyprus 2003, 327-334.

Stylianou, A., 1980, The History of the Cartography of Cyprus. Nicosia.

Stylianou, A. and Stylianou, J. A., 1985, The Painted Churches of Cyprus: Treasures of Byzantine Art. London.

Trentin, M. G., 2007, I graffiti dei pellegrini nelle chiese cipriote. Report of the Department of Antiquities of Cyprus 2007 449-467.

Trentin, M. G., 2010, Mediaeval and post Medieval graffiti in the churches of Cyprus, in S. Christodoulou and A. Satraki (eds), POCA 2007. Postgraduate Cypriot Archaeology Conference, 297-321. Newcastle.

Trentin, M. G., 2011, I graffiti come fonte per lo studio delle pratiche religiose medievali, PhD thesis, University of Venice. http://hdl.handle.net/10579/1079

Van de Moortel, A. and Langdon, M. K., 2017, Archaic Ship Graffiti from Southern Attica, Greece: typology and contextual analysis. IJNA 46.2, 382-405.

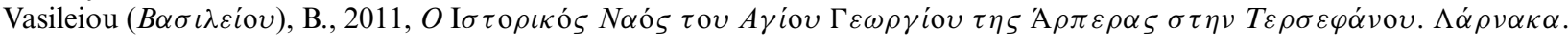

Walsh, M. J. K., 2007, 'On of the Princypalle Havenes of the See': the port of Famagusta and the ship graffiti in the church of St George of the Greeks, Cyprus. IJNA 37.1, 115-129.

Wachsmann, S., 1998, Seagoing ships and seamanship in the Bronze Age Levant. London.

Westerdahl, C., 2013, Medieval carved ship images found in Nordic churches: the poor man's votive ships? IJNA 42.2, 337-347 